\title{
The role of serotonergic system at the interface of aggression and suicide
}

\author{
Marco Bortolato ${ }^{1,}{ }^{,}$, Nela Pivac ${ }^{2}$, Dorotea Muck Seler ${ }^{2}$, Matea Nikolac Perkovic ${ }^{2}$, Mauro \\ Pessia $^{3}$, and Giuseppe Di Giovanni ${ }^{4, *}$ \\ ${ }^{1}$ Department of Pharmacology \& Toxicology, School of Pharmacy, University of Kansas, \\ Lawrence (KS), USA \\ ${ }^{2}$ Division of Molecular Medicine, Rudjer Boskovic Institute, Zagreb, Croatia \\ ${ }^{3}$ Department of Internal Medicine, Section of Human Physiology, University of Perugia, Perugia, \\ Italy \\ ${ }^{4}$ Department of Physiology and Biochemistry, University of Malta, Msida, Malta
}

\begin{abstract}
Alterations in serotonin (5-HT) neurochemistry have been implicated in the aetiology of all major neuropsychiatric disorders, ranging from schizophrenia to mood and anxiety-spectrum disorders. This review will focus on the mulifaceted implications of 5-HT-ergic dysfunctions in the pathophysiology of aggressive and suicidal behaviours. After a brief overview of the anatomical distribution of the 5-HT-ergic system in the key brain areas that govern aggression and suicidal behaviours, the implication of 5-HT markers (5-HT receptors, transporter as well as synthetic and metabolic enzymes) in these conditions is discussed. In this regard, particular emphasis is placed on the integration of pharmacological and genetic evidence from animal studies with the findings of human experimental and genetic association studies.
\end{abstract}

Traditional views postulated an inverse relationship between 5-HT and aggression and suicidal behaviours; however, ample evidence has shown that this perspective may be overly simplistic, and that such pathological manifestations may reflect alterations in 5-HT homeostasis due to the interaction of genetic, environmental and gender-related factors, particularly during early critical developmental stages. The development of animal models that may capture the complexity of such interactions promises to afford a powerful tool to elucidate the pathophysiology of impulsive aggression and suicidability, and find new effective therapies for these conditions.

\section{Keywords}

Impulsive-aggressive behaviours; Suicide; 5-HT; 5-HT receptors; Tryptophan hydroxylase; 5-HT transporter; Monoamine oxidase A

\footnotetext{
(C) 2013 IBRO. Published by Elsevier Ltd. All rights reserved.

*To whom correspondence should be addressed: (MB) Department of Pharmacology \& Toxicology School of Pharmacy University of Kansas, 1251 Wescoe Hall Dr., Rooms 5038-5040 Lawrence, KS 66045 bortolato@ ku.edu or (GDiG.) Department of Physiology and Biochemistry, University of Malta, Msida MSD 2080, Malta. Tel.: +356 23402776 (direct) +356 21316655 (department) +356 21310577 (fax) giuseppe.digiovanni@um.edu.mt.

Publisher's Disclaimer: This is a PDF file of an unedited manuscript that has been accepted for publication. As a service to our customers we are providing this early version of the manuscript. The manuscript will undergo copyediting, typesetting, and review of the resulting proof before it is published in its final citable form. Please note that during the production process errors may be discovered which could affect the content, and all legal disclaimers that apply to the journal pertain.
} 


\section{INTRODUCTION: CHALLENGING THE 5-HT DEFICIENCY HYPOTHESIS IN SUICIDAL BEHAVIOUR}

The definition of suicidal behaviours encompasses a broad constellation of heterogeneous entities, ranging from suicidal thoughts and death wishes to attempted and completed suicide. The great diversity of suicidal behaviours reflect their comorbidity with different psychiatric disorders, including affective disorders, psychoses, alcohol abuse and/or dependence, etc. In particular, numerous studies have been shown a very robust association between multiple aspects of suicidal conducts and aggression. In keeping with this idea, multiple studies have pointed to pathological aggression and antisocial personality as major risk factors for suicide (Conner et al., 2001; Gureje et al., 2011).

The bulk of evidence points to the existence of at least two major subtypes of aggression, characterized by distinct behavioural profiles and neural underpinnings: proactive aggression, typically calculated and instrumental to gaining rewards; and reactive aggression, which is generally enacted impulsively as a stress-coping response to potentially threatening contingencies (Poulin and Boivin, 2000). Research has shown that both subtypes of aggression may influence suicidal conduct. Indeed, reactive aggression and impulsive personality characteristics have been recently highlighted as major risk factors for suicidal ideation and behaviour (Pfeffer et al, 2000; Conner et al, 2003; Dougherty et al, 2004; HullBlanks et al, 2004; Smith et al, 2008). Nevertheless, impulsive actions have been shown to often result in higher likelihood of self-inflicted painful and provocative experiences, but are a relatively rare cause of attempted and completed suicide, which typically requires prior planning (Baca-Garcia et al, 2005; Wyder and De Leo, 2007; Smith et al, 2008; Witte et al, 2008). Conversely, while proactive aggression has been often considered as unrelated to suicide, recent studies have shown that, in men but not women, this subtype is actually associated to suicide attempt (Connor et al, 2009), further underscoring the complex, multifaceted relationship existing between aggressive manifestations and suicidal behaviours.

The neurobiological link between aggression and suicide appears to be contributed by dysregulations in serotonin (5-hydroxytryptamine; 5-HT) neurotransmission. Findings from preclinical and clinical studies have indicated that dysregulations of 5-HT release, signaling and/or turnover may be robust correlates of violent reactivity, suicide (Higley and Linnoila, 1997; Mann et al., 2001; Stanley et al., 2000; Virkkunen et al., 1995) and impulsiveaggressive behaviours (IABs), which have been recently highlighted as critical intermediate phenotypes for suicidal conduct (Mann et al., 2009; Turecki, 2005; Zouk et al., 2007). Notably, both reactive aggression and suicide are affected by multiple biological variables that influence the regulation of 5-HTergic neurotransmission, including psychosocial stress, traumatic experiences, pathological personality traits, mental disorders, alcohol abuse and nicotine addiction (Gibb et al., 2006; Mann et al., 2009; Nock et al., 2008; Pivac et al., 2010; Turecki, 2001). For several decades the link between 5-HT and aggression was explained by a "5-HT deficiency hypothesis", which posited a direct association of reduced CSF concentrations of 5-HT and/or its metabolite 5-hydroxyindoleacetic acid (5-HIAA) and suicidal/aggressive behaviour. Accumulating evidence, however, shows that this theory is inadequate to account for the pleiomorphic role of 5-HT in the modulation of pathological aggression and suicidal behaviours; thus, current views postulate that IABs may be the final outcome of different homeostatic imbalances of the 5-HT system.

In the following section, we will briefly describe the 5-HT innervations of the forebrain regions involved in impulsive-aggressive behaviours and suicidal behaviours, such as the medial prefrontal cortex (mPFC), orbitofrontal cortex (OFC), amygdala and nucleus accumbens (Davidson et al., 2000) (Fig. 1). In addition, we will overview the preclinical and 
clinical evidence on the best-characterized 5-HT-ergic targets implicated in violent and suicidal behaviours, including its receptors, its key biosynthetic enzyme tryptophan hydroxylase (TPH), its transporter (5-HTT) and the main catabolic enzyme, monoamine oxidase (MAO) A (Fig. 2).

\section{THE SEROTONERGIC SYSTEM IN AGGRESSION AND SUICIDE}

One of the oldest biologically active compounds, 5-HT is found across all eukaryote kingdoms, including protists, plants, fungi and animals. Given its ubiquitous presence in the body, it is not surprising that 5-HT is involved in a plethora of physiological and pathophysiological processes (Jacobs and Azmitia, 1992). Based on the distribution of 5-HT in the organism, its system can be divided into a central and a peripheral subsystem (Murphy et al., 2008a); the latter, which includes the gastrointestinal (GI) tract, lung, heart, pancreatic tissue, blood vessels and platelets (Cirillo et al., 2011; Thompson, 1971), contains the greatest concentration (90\%) of 5-HT (up to $10 \mathrm{mg}$ in humans). Conversely, only a relatively small amount of 5-HT is found in the in the central nervous system (CNS). The central 5-HT subsystem is one of the diffusively organized projection systems of the mammalian brain and it is topographically organized with respect to anatomic and functional properties (Abrams et al., 2004). The majority of the cell bodies of the 5-HT-ergic neurons are located in the raphé nuclei, within the reticular formation of the brainstem. Although the 5-HT-ergic neurons are multipolar, their size and orientation vary considerably across distinct locations; in fact, their complex axonal systems innervate virtually all CNS regions, although their distribution is particularly dense in the cerebral cortex, limbic structures, basal ganglia, many regions of the brainstem and the gray matter of the spinal cord.

Dahlstrom and Fuxe (Dahlstrom and Fuxe, 1964) clustered the 5-HT neurons in the rat brainstem into nine nuclei, termed B1 to B9 (B1 being the most caudal one) (Fig. 1). In addition, these midline clusters can be further categorized into two major groups:

- $\quad$ the caudal or inferior group, localized in the medulla, which contains three nuclei projecting essentially to the grey matter of the spinal cord: the nucleus raphe magnus (NRM, cell group B5), nucleus raphe obscurus (NRO, cell groups B1-B2-B3), and nucleus raphe pallidus (NRP, cell group B4);

- $\quad$ the rostral or superior group, situated in the pons and midbrain, which contains the dorsal raphe nucleus (DRN, cell groups B6 and B7, estimated to contain 235,000 neurons in the human brain (Baker et al., 1990) and the median raphe nucleus (MRN, cell group B8) (Fig. 1). The main target regions of these 5-HTergic projections are located in the forebrain and spinal cord.

\subsection{Serotonergic innervation and $5-\mathrm{HT}$ receptors distribution in prefrontal cortex (PFC), amygdala and nucleus accumbens}

The ascending projections of 5-HT neurons are very extensive, and their collateral branches innervate numerous regions of the cerebral cortex, basal ganglia, limbic system and diencephalon. Although all the axons travel within the medial forebrain bundle in their initial tracts, many of them extend from this structure, following other fiber pathways up to their target areas.

2.1.1 The 5-HT-ergic system in the PFC-The 5-HT innervation of the cerebral cortex originates from the midbrain DRN and MRN, and spreads to every allo- and iso-cortical area, with variable fiber density across the different layers. In primates, the 5-HT-ergic innervation of the cortex is particularly dense in the granular cell layers (layer IV) (Hillegaart, 1991; Van Bockstaele et al., 1993). The rich 5-HT-ergic innervations of the 
mPFC (as well as most of the frontal cortex) originates almost exclusively in the DRN (Van Bockstaele et al., 1993). The OFC is also primarily innervated by the DRN (Murphy et al.), and contains an extremely dense plexus of fine axons featuring minute varicosities. Axonal tracing studies show that DRN neurons project to the frontal cortex following wellcharacterized rostro-caudal and dorso-ventral topographic patterns (Waterhouse et al., 1986). The MRN innervation consists of few thick, beaded serotonergic axons with large spherical varicosities (Wilson and Molliver, 1991). The distribution of the 5-HT-ergic innervation varies according to the types of cortex and the cytoarchitectonic regions; thus, 5HTT density in agranular/dysgranular (caudal) OFC is higher than that in granular (rostral) $\mathrm{OFC}$, and there is a medial-to-lateral decreasing gradient within the agranular/dysgranular regions (Way et al., 2007). The OFC and mPFC send direct projections down to the raphé nuclei, providing a substrate for top-down control over the 5-HT-ergic forebrain pathways.

The PFC features an abundant expression of several 5-HT receptor families. In particular, members of the $5-\mathrm{HT}_{1}$ receptor family such as $5-\mathrm{HT}_{1 \mathrm{~A}}$ and $5-\mathrm{HT}_{1 \mathrm{~B}}$, are localized both presynaptically (autoreceptors) on the dendrites of 5-HT fibres and postsynaptically (heteroreceptors) on pyramidal cells and different types of interneurons (Azmitia et al., 1996; Santana et al., 2004). Activation of postsynaptic 5- $\mathrm{HT}_{1 \mathrm{~A}}$ and 5- $\mathrm{HT}_{1 \mathrm{~B}}$ receptors in the pyramidal cells of cortex produces hyperpolarizing responses, while presynaptic $5-\mathrm{HT}_{1}$ receptors, reduces the amplitude of electrically evoked excitatory postsynaptic potentials (EPSPs), including both N-methyl-D-aspartate (NMDA) and non-NMDA glutamate receptors (Tanaka and North, 1993). Conversely, in vivo treatment with a low dose of 5$\mathrm{HT}_{1 \mathrm{~A}}$ receptor agonist 8-OH-DPAT activates these receptors on Y-amino-butyric-acid (GABA)-ergic interneurons, leading to an indirect increase of the discharge rate of pyramidal neurons in mPFC (Llado-Pelfort et al., 2012). 5- $\mathrm{HT}_{2 \mathrm{~A} / 2 \mathrm{c}}$ receptors are also densely distributed in the PFC; $5-\mathrm{HT}_{2 \mathrm{~A}}$ are co-expressed with $5-\mathrm{HT}_{1 \mathrm{~A}}$ in pyramidal cells and parvalbumin (PV)- and calbindin (Mann et al.)-containing GABA-ergic interneurons (Santana et al., 2004). 5- $\mathrm{HT}_{2 \mathrm{~A}}$ receptors activation induces depolarization of both cell types (Aghajanian and Sanders-Bush, 2002). Electrophysiologically, in layer V pyramidal cells, synaptic events induced by $5-\mathrm{HT}_{2 \mathrm{~A}}$ consist largely of excitatory postsynaptic potentials (EPSPs) although inhibitory postsynaptic potentials (IPSPs) can be recorded due to GABAergic interneurons activation (Aghajanian and Sanders-Bush, 2002). The 5- $\mathrm{HT}_{2 \mathrm{C}}$ receptor is primarily expressed in the deep layers of the rat mPFC by calcium-binding proteins-positive GABAergic interneurons in rat pyramidal cells (Liu et al., 2007), while its mRNA is absent in pyramidal-shaped cells in both human and monkey PFC (Pasqualetti et al., 1999). Activation of 5- $\mathrm{HT}_{2 \mathrm{C}}$ receptors induces neuronal depolarization (Di Giovanni et al., 2008b; 2011). Thus, the pyramidal cell inhibition seen by stimulation of the $5-\mathrm{HT}_{2 \mathrm{C}}$ receptor is likely due to excitation of PV-positive interneurons in the mPFC (Di Giovanni et al., 2011). The expression of 5- $\mathrm{HT}_{2 \mathrm{C}}$ receptors in the deep layers of the rat $\mathrm{mPFC}$ (layers $\mathrm{V}-\mathrm{VI}$ ), suggests that the action of $5-\mathrm{HT}_{2} \mathrm{C}$ receptor may modulate the neuronal output in these layers (Liu et al., 2007).

Several lines of evidence indicate that the other 5-HT receptors are also expressed in the neocortex. In particular, $5-\mathrm{HT}_{3}$ receptors are mainly localized in the superficial layers of the cortex and particularly abundant in GABAergic interneurons (Miquel et al., 2002; Morales and Bloom, 1997; Puig et al., 2004; Tecott et al., 1993). With respect to the distribution of other 5-HT receptors in the PFC, 5- $\mathrm{HT}_{4}$ are particularly expressed in superficial layers (Varnäs et al., 2003) and mostly in pyramidal neurons (Lambe et al., 2011); conversely, 5$\mathrm{HT}_{6}$ are relatively sparse (Marazziti et al., 2012) and mostly localized in the interneurons (Lambe et al., 2011). Finally, 5- $\mathrm{HT}_{7}$ receptors have also been documented in the frontal pole of the neocortex of rodents and humans (Gustafson et al., 1996; To et al., 1995). The function of these receptors in the cortex is still poorly understood. 
2.1.2. The 5-HT-ergic system in the amygdala-In all species studied to date, the amygdala features an exceptionally rich 5-HT-ergic innervation, arising mainly from the DRN (Smith and Porrino, 2008); virtually all neuropeptide Y (NPY)-immunoreactive (ir) neurons receive peri-somatic serotonergic innervations (Bonn et al., 2012). 5- $\mathrm{HT}_{1 \mathrm{~A}}, 5-\mathrm{HT}_{2 \mathrm{~A}}$ expression has been found in both pyramidal cells and inhibitory interneurons (Aznar et al., 2003; McDonald and Mascagni, 2007). 5- $\mathrm{HT}_{1 \mathrm{~B}}$ receptors are also expressed in different amygdaloid nuclei and their expression increases in rats exposed to aggression only in the basolateral amygdala (Suzuki et al., 2010). The cellular expression of 5- $\mathrm{HT}_{2 \mathrm{C}}$ receptors in pyramidal neurons of the amygdala has not been studied yet, but recent evidence shows that NPY mRNA-producing interneurons co-express both 5- $\mathrm{HT}_{1 \mathrm{~A}}$ and 5- $\mathrm{HT}_{2 \mathrm{C}}$ mRNAs (Bonn et al., 2012). Although these anatomical findings are difficult to reconcile with the anxiogenic activity of 5- $\mathrm{HT}_{2 \mathrm{C}}$ and the anxiolytic or mixed effects of $5-\mathrm{HT}_{2} \mathrm{~A}$ and $5-\mathrm{HT}_{1 \mathrm{~A}}$ receptor activation, it is likely that these divergent roles reflect the high complexity of the circuits for emotional regulation, as well as the different patterns of 5-HT receptor neuronal distribution (Holmes, 2008). Of the other 5-HT receptors, $5-\mathrm{HT}_{3}, 5-\mathrm{HT}_{4}$ and $5-\mathrm{HT}_{7}$ have been shown to be fairly abundant in amygdala (Gustafson et al., 1996; Miquel et al., 2002; Reynolds et al., 1995; Varnäs et al., 2004; Waeber et al., 1994), but their role in behavioral regulation awaits further examination.

2.1.3. The 5-HTergic system in the NAc-The NAc receives an extensive, dense innervation by 5-HT-ir axons, which are tortuous and of consistent morphology (Van Bockstaele and Pickel, 1993). Both the NAc core and shell are densely innervated by 5-HTergic projections from the cell bodies in the dorsal raphe; these projections differ in regional distribution, morphology, and 5-HTT expression, and can be divided into two distinct types of 5-HT axons (Brown and Molliver, 2000). Furthermore, within the NAc, the shell contains a higher density of 5-HT axons than the core (Brown and Molliver, 2000). The NAc contains several types of 5-HT receptors. 5- $\mathrm{HT}_{1 \mathrm{~A}}$ receptors are expressed in very low levels (Aznar et al., 2003), while 5- $\mathrm{HT}_{1 \mathrm{~B}}$ receptors are expressed on the soma of GABAergic neurons, as well as on the terminals of the axons that project to the ventral tegmental area (VTA) (Morikawa et al., 2000). Moreover, 5- $\mathrm{HT}_{1 \mathrm{~B}}$ heteroreceptors are also distributed in presynaptic glutamate elements (Muramatsu et al., 1998). Both 5- $\mathrm{HT}_{2 \mathrm{~A}}$ and 5-HT $2 \mathrm{C}$ receptors are expressed in moderate-to-high abundance within both the cell body and terminal regions of the NAc (Di Giovanni et al., 2011; Di Matteo et al., 2008).

Investigations on the role of $5-\mathrm{HT}_{2 \mathrm{~A} / 2 \mathrm{c}}$ receptors in the NAc have revealed a complex scenario, with opposing effects for 5- $\mathrm{HT}_{2 \mathrm{~A}}$ and $5-\mathrm{HT}_{2 \mathrm{C}}$ receptors (Robinson et al., 2008). In addition, $5-\mathrm{HT}_{4}$ and $5-\mathrm{HT}_{6}$ receptors have been shown to be highly abundant in the NAc (Bonaventure et al., 2000; Compan et al., 1996; Gerard et al., 1997; Hamon et al.,1999; Marazziti et al., 2012; Varnäs et al., 2003), although their functional roles in this area remain largely elusive.

\subsection{The role of $5-\mathrm{HT}_{1}$ receptors in aggression and suicide}

The $5-\mathrm{HT}_{1}$ receptor class is comprised of five receptor subtypes $\left(5-\mathrm{HT}_{1 \mathrm{~A}}, 5-\mathrm{HT}_{1 \mathrm{~B}}, 5-\mathrm{HT}_{1 \mathrm{D}}\right.$, 5 -ht ${ }_{1 \mathrm{E}}$ and 5-ht $1 \mathrm{~F}$ ), which, in humans, share $40-63 \%$ overall sequence identity, and couple preferentially, although not exclusively, to Gi/o proteins to inhibit cAMP formation. While no physiological role has been found for the $5-\mathrm{ht}_{1 \mathrm{E}}$ and $5-\mathrm{ht}_{1 \mathrm{~F}}$ receptors, the function of 5$\mathrm{HT}_{1 \mathrm{~A}}, 5-\mathrm{HT}_{1 \mathrm{~b}}$ and $5-\mathrm{HT}_{1 \mathrm{D}}$ receptors has been demonstrated in many tissues across various species (Di Giovanni et al., 2008a). Although all 5-HT receptor subtypes are localized postsynaptically on 5-HT target cells (including all key regions involved in hostile and suicidal behaviours), the 5- $\mathrm{HT}_{1 \mathrm{~A}}$ and $5-\mathrm{HT}_{1 \mathrm{~B}}$ subtypes are also present in the presynaptic elements of 5-HT neurons. In the raphé nuclei, $5-\mathrm{HT}_{1 \mathrm{~A}}$ autoreceptors are localized on 5-HT cell bodies and dendrites; conversely, $5-\mathrm{HT}_{1 \mathrm{~B}}$ receptors are expressed presynaptically on 5- 
HT nerve terminals, where they subserve the regulation of 5-HT release (Di Giovanni et al., 2008a).

2.2.1. 5- $-\mathrm{HT}_{1 \mathrm{~A}}$ receptors-The implication of 5-HT $\mathrm{H}_{1 \mathrm{~A}}$ receptors in aggression and suicide is supported by numerous lines of evidence. In particular, several studies have documented that $5-\mathrm{HT}_{1 \mathrm{~A}}$ receptor agonists attenuate offensive-aggressive (but not defensive) responses in animal models, even at doses that do not appear to cause motor impairments (Bell and Hobson, 1994; Lopez-Mendoza et al., 1998; Muehlenkamp et al., 1995; Olivier et al., 1989; Sanchez et al., 1993; White et al., 1991; Yoshimura and Ogawa, 1991). The effects of 5$\mathrm{HT}_{1 \mathrm{~A}}$ agonists on the modulation of aggressive responses have been shown to depend on the activation of multiple populations of $5-\mathrm{HT}_{1 \mathrm{~A}}$ receptors, located across several brain regions, including periaqueductal gray (Beckett et al., 1992; De Almeida and Lucion, 1997; Mann et al., 2009), raphé nuclei (da Veiga et al.,; Mos et al., 1993), medial septal area (De Almeida and Lucion, 1997) and ventral OFC (Centenaro et al., 2008). While the administration of 5$\mathrm{HT}_{1 \mathrm{~A}}$ receptor antagonists blocks the antiaggressive effects of 5-HT $\mathrm{HT}_{1 \mathrm{~A}}$ receptor agonists (Sanchez and Hyttel, 1994) [but see also (Pruus et al., 2000) for contrasting results], these compounds elicit no significant effects on offensive, defensive and social behaviours (Bell et al., 1999; Lopez-Mendoza et al., 1998).

In general, the antiaggressive effects of systemic $5-\mathrm{HT}_{1 \mathrm{~A}}$ receptor agonists are likely to mostly reflect the anxiolytic effects of autoreceptor activation, in consideration of the predominance of this subpopulation of 5- $\mathrm{HT}_{1 \mathrm{~A}}$ receptors, as well as the well-known role of anxiety and fear as primary triggers for aggressive responses. In this perspective, it is possible that the selective activation of post-synaptic $5-\mathrm{HT}_{1 \mathrm{~A}}$ receptors in specific forebrain areas may lead to different modulatory effects on hostile behaviours. Accordingly, rodents genetically selected for high levels of aggressive behaviour exhibit distinct alterations of expression and sensitivity of $5-\mathrm{HT}_{1 \mathrm{~A}}$ receptor across cortical and subcortical regions (Caramaschi et al., 2007; Korte et al., 1996; Popova et al., 2007; Popova et al., 2005).

Most studies have indicated that aggressive animals and individuals exhibit blunted behavioural and neuroendocrine responses to $5-\mathrm{HT}_{1 \mathrm{~A}}$ receptor agonists (Cleare and Bond, 2000; Coccaro et al., 1990; Popova et al., 2005); in addition, the levels of lifetime aggression were negatively correlated with overall levels $5-\mathrm{HT}_{1 \mathrm{~A}}$ receptor binding (Parsey et al., 2002). However, it should be noted that aggressive subjects were also reported to exhibit higher 5- $\mathrm{HT}_{1 \mathrm{~A}}$ receptor binding levels in the prefrontal and anterior cingulate cortex (Witte et al., 2009), probably in view of the differential role of auto- and heteroreceptors in the regulation of aggression.

The potential involvement of $5-\mathrm{HT}_{1 \mathrm{~A}}$ receptors in suicidal behaviours has been studied through post-mortem brain assessments of the kinetic characteristics of these receptors in suicide victims. The results of these studies, however, are often affected by a number of experimental confounds, such as the lack of adequate controls or the comorbidity of suicide with other anxiety and mood disorders, whose pathophysiology may reflect different (and sometimes opposite) patterns of 5-HTergic alterations than those typically associated with aggression. For example, 5- $\mathrm{HT}_{1 \mathrm{~A}}$ binding was found to be increased in the dorsal and ventral DRN (Stockmeier et al., 1998) and cortex (Arango et al., 1995) of suicidal subjects with major depression; conversely, another study found no alterations in binding to 5- $\mathrm{HT}_{1 \mathrm{~A}}$ receptors in 5-HTergic terminal areas, such as frontal and occipital cortices, hippocampus and amygdala in depressed suicide victims (Lowther et al., 1997). In addition to the methodological caveats listed above, these discrepancies may also reflect different influences of gender-related factors (Anisman et al., 2008). 
The potential implication of $5-\mathrm{HT}_{1 \mathrm{~A}}$ receptors in suicide has also been analyzed with genetic approaches. 5- $\mathrm{HT}_{1 \mathrm{~A}}$ receptor is coded by HTR1A, an intronless $2.1 \mathrm{~kb}$ gene located at position $5 \mathrm{q} 11.2-\mathrm{q} 13$, whose expression is likely regulated by two transcription factors: Nuclear deformed epidermal auto regulatory factor-1 (NUDR/Deaf-1) and Hes5 (Czesak et al., 2006; Lemonde et al., 2003; Szewczyk et al., 2009) (Table 1). NUDR/Deaf-1 is a repressor at somatodendritic 5- $\mathrm{HT}_{1 \mathrm{~A}}$ receptors (Lemonde et al., 2003), but serves as a transcription enhancer in non-5-HT-ergic neurons that express postsynaptic 5 - $\mathrm{HT}_{1 \mathrm{~A}}$ receptors. Although several single nucleotide polymorphisms (SNPs) have been found in HTR 1A (Drago et al., 2008), the best-characterized one is C-1019G (rs6295), a functional polymorphism in the promoter region that regulates gene expression (Lemonde et al., 2003). In particular, it has been suggested that the G-1019 may modulate negatively the function NUDR/Deaf-1 on HTR1A (Lemonde et al., 2003), possibly leading to compensatory increases in expression of presynaptic 5- $\mathrm{HT}_{1 \mathrm{~A}}$ but decreases in expression of the postsynaptic 5-HT $1 \mathrm{~A}$ receptors in G-1019 allele carriers (Albert and Francois, 2010). Nevertheless, it should be noted that no significant association was found between C-1019G genotype and regional binding potential of two selective $5-\mathrm{HT}_{1 \mathrm{~A}}$ antagonists ${ }^{11} \mathrm{C}$ WAY100635 (David et al., 2005) or ${ }^{18}$ F-MPPF (Lothe et al., 2010) using positron emission tomography (PET) in healthy subjects.

Among the many studies conducted on potential associations between $H T R 1 A$ variants and suicide in Caucasian (Lemonde et al., 2003; Serretti et al., 2009; Serretti et al., 2007; Videtic et al., 2006; Wasserman et al., 2006) and Japanese (Nishiguchi et al., 2002; Ohtani et al., 2004) populations, only one (Lemonde et al., 2003) has documented a significant association between higher frequency of G-1019 allele and GG genotype in patients with depression and suicide victims than in non-suicidal healthy controls. The authors have posited that this association may be explained by a reduction of 5-HT-ergic activity in G carriers due to the inhibitory actions of this variant on NUDR/Deaf-1-mediated repression of 5-HT $1 \mathrm{~A}$ autoreceptors (Lemonde et al., 2003). Notably, recent evidence has documented an association between homozygosity for the $\mathrm{G}$ variant and impulsiveness (Benko et al., 2010), a trait typically linked to reduced 5-HTergic activity.

In summary, the available evidence on the implication of 5- $\mathrm{HT}_{1 \mathrm{~A}}$ receptors appears to converge on the idea that IABs may be associated with a reduced activity and/or expression of the autoreceptors. The functional evidence from evidence supports the possibility that, while these receptors may not play a primary causal role in impulsivity and aggression, their key involvement in anxiety regulation and in the adaptive responses to abnormalities of 5HTergic homeostasis may highlight them as attractive therapeutic targets to reduce the impact of the conditions that trigger explosive and violent behaviours. Nevertheless, further studies will be needed to elucidate the nature of the multiple discrepancies emerging from the preclinical and clinical literature, as well as the putative roles of pre- and post-synaptic $5-\mathrm{HT}_{1 \mathrm{~A}}$ receptors in the regulation of violent and suicidal behaviours, also with respect to multiple comorbid entities.

2.2.2. 5- $\mathrm{HT}_{1 \mathrm{~B}}$ receptors - In rodents, activation of 5- $\mathrm{HT}_{1 \mathrm{~B}}$ receptors induces a marked reduction of escalated aggression in a highly specific fashion, which appears to be dissociated from alterations of exploration, locomotion and anxiety-related behaviours (Bell et al., 1995; de Almeida et al., 2001; Fish et al., 1999; Miczek et al., 1989; Mos et al., 1992; Muehlenkamp and Gutierrez, 2004; Sijbesma et al., 1990). The systemic effects of 5-HT $1 \mathrm{~B}$ receptor agonists are reproduced by microinjections of these compounds in the ventral OFC and raphe nuclei, but not infralimbic prefrontal cortex (Bannai et al., 2007; Centenaro et al., 2008; De Almeida et al., 2006). The mechanism underpinning the role of 5- $\mathrm{HT}_{1 \mathrm{~B}}$ in the modulation of reactive aggression may reflect its role on both post-synaptic heteroceptors (Mos et al., 1992; Olivier, 2004) as well as 5-HT 1 B autoreceptors (Clark and Neumaier, 
2001; de Boer and Koolhaas, 2005), probably in relation to different facets of aggressive conduct. This pharmacological evidence is complemented by the finding of overt impulsive and antagonistic behaviours, behavioural disinhibition and increased alcohol intake (Bouwknecht et al., 2001; Crabbe et al., 1996; Risinger et al., 1999; Saudou et al., 1994) in $5-\mathrm{HT}_{1 \mathrm{~B}}$ knockout $(\mathrm{KO})$ mice. Collectively, these preclinical results support a highly more specific and direct role of these receptors in the pathophysiology of reactive aggression, suicidal behaviour and alcoholism (Cao et al., 2011; Soyka et al., 2004).

The human 5-HT 1 B receptor is a 390 amino acid-long peptide, encoded by HTR1B, an intronless gene (1.1 kb long) located on chromosome 6 (6q14.1) (Sanders et al., 2001) (Table 1). Seventy-two polymorphisms have been discovered in the coding sequence and surrounding 5' and 3' untranslated regions. Using denaturing gradient gel electrophoresis (DGGE), Sanders and colleagues (Sanders et al., 2001) characterized 12 SNPs and two insertion/deletion (INS/DEL) polymorphisms within HTR1B gene. The INS/DEL polymorphisms are -179INS/DEL-178 and -182INS/DEL-181. Among SNPs, G-511T and T-216G are detected in the 5' (Nothen et al., 1994; Sanders et al., 2001), 2001) and A-161T in 3' noncoding regions (Sanders et al., 2001). Four SNP are synonymous or silent mutations: C129T (Ser43Ser), G276A (Ala92Ala), C705T (Ala235Ala) and G861C (Val287Val) (Cargill et al., 1999; Lappalainen et al., 1995; Ohara et al., 1996; Sanders et al., 2001). The latter genotype is in almost complete linkage disequilibrium with C129T (Huang et al., 1999) and T317G (Sanders et al., 2001), and may be linked to functional differences. In fact, $\mathrm{C}$ allele carriers have been shown to display lower binding of ${ }^{3} \mathrm{H}-5-\mathrm{HT}$ to $5-\mathrm{HT}_{1 \mathrm{~B}}$ receptors (Huang et al., 1999). Other non-synonymous polymorphisms have been found to change the amino acids in second (T371G; Phe124CysT), fifth (T655C; Phe219Leu) and seventh (A1099G; 1le367Val9) transmembrane and intracellular C terminal (G1120A, Glu374Lys), His452Tyr) regions of 5-HT 1 B receptors (Sanders et al., 2001).

The association studies that investigated allelic variability at the $H T R 1 B$ in suicide attempters and suicide completers have led to inconsistent results. No association was found between genotype or allele frequency of G861C or A-161T polymorphisms and suicide or suicide history in Caucasians of German (Rujescu et al., 2003; Stefulj et al., 2004), Croatian (Stefulj et al., 2004), Slovenian (Videtic et al., 2006) and French Canadian (Turecki et al., 2003) origin, as well as in African American (Huang et al., 1999; Huang et al., 2003), Japanese (Nishiguchi et al., 2001), or Han Chinese (Hong et al., 2004; Tsai et al., 2004) subjects. In contrast, New et al (New et al., 2001) found that Caucasian patients with personality disorder and a history of suicide attempts had higher frequency of $\mathrm{G}$ allele of G861C polymorphism than patients without suicide history. Another study reported an association between the T allele in the A-161 T polymorphism and suicide or impulsiveaggressive behaviour. However, no association was found with other four SNPs (T261G, C129T; G861C; A1180G) (Zouk et al., 2007). Other variants associated with microRNAdirected silencing of 5- $\mathrm{HT}_{1 \mathrm{~B}}$ transcription were recently correlated with higher risk for conduct disorder and greater anger and hostility in young men (Conner et al., 2010; Jensen et al., 2009).

Taken together, preclinical and clinical evidence appears to concur in assigning a putative causal role for hypofunctional 5- $\mathrm{HT}_{1 \mathrm{~B}}$ receptors in IABs. Despite these promising research leads, further studies on the selective role of pre- and post-synaptic receptors and clinical studies with larger number of subjects are needed to clarify the association between $5-\mathrm{HT}_{1 \mathrm{~B}}$ receptors and aggressive-impulsive endophenotypes, as well as their involvement in suicidal behaviours. 


\subsection{The role of $5-\mathrm{HT}_{2}$ receptors in aggression and suicide}

$5-\mathrm{HT}_{2}$ receptors form a closely related subgroup of G-protein-coupled receptors, functionally linked to the phosphatidylinositol hydrolysis pathway and currently classified as 5- $\mathrm{HT}_{2 \mathrm{~A}}, 5-\mathrm{HT}_{2 \mathrm{~B}}$ and $5-\mathrm{HT}_{2 \mathrm{C}}$ subtypes, based on their close structural homology and pharmacology (Di Giovanni et al., 2008a). Initial studies on 5- $\mathrm{HT}_{2}$ receptor signalling showed that these receptors activate the heterotrimeric $\mathrm{G}$ proteins that contain the aq subunit, thereby stimulating phospholipase $\mathrm{C} \beta$ and leading to phosphatidyl inositol hydrolysis (Di Giovanni et al., 2011). These receptors also stimulate phospholipase A2 and the NO/cyclic GMP (cGMP) pathway. However, some differences in the signal transduction characteristics of these receptors have been reported (Di Giovanni et al., 2011; Imbrici et al., 2000). Studies focusing on the regulation of the $5-\mathrm{HT}_{2}$ receptor family have also indicated that $5-\mathrm{HT}_{2}$ receptors are non-classically regulated and show constitutive activity (Di Giovanni et al., 2008a; 2011).

2.3.1. 5- $-\mathrm{HT}_{2 \mathrm{~A}}$ receptors-Although both agonists and antagonists of $5-\mathrm{HT}_{2 \mathrm{~A}}$ receptors have been shown to reduce hostile behaviours (Olivier et al., 1995; Sakaue et al., 2002; White et al., 1991) [for contrasting results, see (Skrebuhhova-Malmros et al., 2000)], the interpretation of these findings is often complicated by the side effects of these compounds, such as the cognitive deficits induced by $5-\mathrm{HT}_{2 \mathrm{~A}}$ agonists and the sedative and hypolocomotive effects of their blockers (de Almeida et al., 2005). Little is currently known about the roles of different regions in the role of 5- $\mathrm{HT}_{2 \mathrm{~A}}$ receptors in aggression; however, local infusion of 5- $\mathrm{HT}_{2}$ agonists into the $\mathrm{PAG}$ was found to attenuate maternal aggression in rats (de Almeida et al., 2005).

In contrast with evidence on rodents, converging lines of evidence have pointed to the implication of 5- $\mathrm{HT}_{2 \mathrm{~A}}$ receptors in aggression. For example, $5-\mathrm{HT}_{2 \mathrm{~A}}$ receptor expression in platelets has been correlated to the severity of hostile traits (Coccaro et al., 1997); however, this index has been shown to be unreliable as a suicidality marker (Lauterbach et al., 2006). Other studies have identified inverse correlations between $5-\mathrm{HT}_{2 \mathrm{~A}}$ expression and activity in the $\mathrm{PFC}$ and $\mathrm{OFC}$ with aggression. For example, low levels of 5-HT $2 \mathrm{~A}$ binding potential have been found in the PFC of violent aggressive individuals (Meyer et al., 2008). In males, a negative correlation was found between $5-\mathrm{HT}_{2 \mathrm{~A}}$ binding in left orbital and medial frontal cortex and aggression severity (Soloff et al., 2010). In contrast with these data, prefrontal 5$\mathrm{HT}_{2}$ binding (as tested by ${ }^{3} \mathrm{H}$ ketanserin) has been found to be directly correlated with lifetime aggression scores in suicidal subjects (but not in their controls) (Oquendo et al., 2006); furthermore, $5-\mathrm{HT}_{2 \mathrm{~A}}$ receptor availability in the $\mathrm{OFC}$ has been recently correlated with a state measure of impulsive aggression (Rosell et al., 2010).

Another important line of research to assess the implication of 5- $\mathrm{HT}_{2 \mathrm{~A}}$ receptors in the pathophysiology of aggression comes from genetic association studies. The $64 \mathrm{~kb}$ gene coding the $5-\mathrm{HT}_{2 \mathrm{~A}}$ receptor $(H T R 2 A)$ is located on the long arm of chromosome 13 at position 13q14-q21 (Sparkes et al., 1991), and is comprised of three exons and two introns, with translation length of 471 residues (NCBI Gene 2012) (Table 1). A silencer element found downstream of the second promoter element suggests that HTR $2 A$ contains two alternative promoters (Myers et al., 2007; Serretti et al., 2007). Although almost 300 different SNPs within HTR2A have been listed (Fanous et al., 2009; Serretti et al., 2007) (Table 2), only a few are well-documented (Serretti et al., 2007):

- $\quad$ two silent mutations in the coding region, T102C and C516T (Spurlock et al., 1998);

- $\quad$ nine polymorphisms are located in the promoter region (Myers et al., 2007), the best-characterized of which is the A-1438G; 
- $\quad$ five non-synonymous polymorphisms in the extracellular $\mathrm{N}$ terminal (polymorphism Thr25Asn), fourth transmembrane (lle197Val) and intracellular C terminal (Ser421Phe, Ala447Val, His452Tyr) regions (Davies et al., 2006).

The synonymous mutation T102C (rs6313) is located in the first exon of the HTR2A. The substitution of base thymine $(\mathrm{T})$ with cytosine $(\mathrm{C})$ encodes in both cases for the amino acid serine in codon 34 of the HTR $2 A$ and do not change the amino-acid sequence of the protein. Although T102C represents a silent polymorphism, it is positioned close to the promoter region and could be involved in gene regulation (Serretti et al., 2007) by changing the secondary structure of transcript or by prevention of gene expression by methylation of cytosine in position 102 (Vaquero-Lorenzo et al., 2008).

The $\mathrm{G}$ to $\mathrm{A}$ base change at position -1438 (rs6311) is in total linkage disequilibrium with $\mathrm{T}$ to $\mathrm{C}$ base change at silent polymorphism T102C (Kouzmenko et al., 1999; Ono et al., 2001; Spurlock et al., 1998) implying these two polymorphisms could be considered together. The functional role of SNP T102C or A-1438G is not clear. In healthy individuals, TT carriers were shown to exhibit a higher number of $5-\mathrm{HT}_{2 \mathrm{~A}} \mathrm{R}$ binding sites (Bmax) in blood platelets (Khait et al., 2005) and brain (Turecki et al., 1999), as compared with TC and CC genotype carriers. Post-mortem brain analyses have shown higher expression of HTR $2 A$ mRNA in temporal cortex of healthy subjects with TT genotype in some (Polesskaya and Sokolov, 2002) but not all (Bray et al., 2004) studies. In contrast, the A-1438G genotype was found to have no association with the $5-\mathrm{HT}_{2 \mathrm{~A}} \mathrm{R}$ density in post-mortem samples of the lateral frontal cortex of schizophrenia patients and healthy probands (Kouzmenko et al., 1999).

The 5- $\mathrm{HT}_{2 \mathrm{~A}}$ His452Tyr (1354 C/T; rs6314) polymorphism is positioned in exon 3 of the $H T R 2 A$ gene. This missense mutation consists of a C-T base substitution, resulting in the change of the amino acid hystidine (His) into tyrosine (Tyr) at position 452 in the C-terminal region of the $5-\mathrm{HTR}_{2 \mathrm{~A}}$ receptor. The most common variant is $\mathrm{C}$ allele (His452His), while the frequency of $\mathrm{T}$ allele is approximately $9 \%$ in Caucasians (Filippini et al., 2006). The His452Tyr is a functional polymorphism that regulates the $5-\mathrm{HT}_{2 \mathrm{~A}}$ receptor activity throughout the regulation of $\mathrm{Ca}^{2+}$ fluctuation in cells (Ozaki et al., 1997) and activation of phospholipases C and D (Hazelwood and Sanders-Bush, 2004) with 452Tyr being the less active variant.

Several studies have documented significant associations between the severity or the incidence of aggression and anger traits with specific polymorphic functional variants of the gene encoding for this receptors, including the SNPs T102C (Assal et al., 2004) and the A1438G genotypes (Berggard et al., 2003). Interesting, the latter polymorphism has been shown to influence the risk of impulsive behaviour (Nomura and Nomura, 2006) and suicidality (Giegling et al., 2006). Finally, the SNP His452Tyr has been associated with rule-breaking components of antisocial behaviour in adolescence, but not physical aggression (Burt and Mikolajewski, 2008). It should be mentioned, however, that other studies have failed to identify associations between genetic variants of $5-\mathrm{HT}_{2 \mathrm{~A}}$ and aggression in suicide victims (Videtic et al., 2006) and alcoholic patients (Preuss et al., 2000). Furthermore, most of the studies failed to find a significant association between T102C or His452Tyr and suicidal ideation (Bondy et al., 2000; Fanous et al., 2009; Preuss et al., 2000) suicide attempts (Arias et al., 2001; Correa et al., 2007; Etain et al., 2004; Giegling et al., 2006; Khait et al., 2005; Oswald et al., 2003; Preuss et al., 2000; Saiz et al., 2008; Tan et al., 2002; Zalsman et al., 2005; Zhang et al., 2008), severity of suicidal behaviour (De Luca et al., 2008a), suicide (Bondy et al., 2000; Crawford et al., 2000; Faludi et al., 2000; Ono et al., 2001), suicidal behaviour (Ertugrul et al., 2004; Murphy et al., 2011) or completed suicide (Turecki et al., 1999). Few studies found significant association between T102C CC genotype and suicide in suicide attempters compared to healthy control but not psychiatric controls (Vaquero-Lorenzo et al., 2009), or in depressed patients with 
suicide ideation (Du et al., 2000). In addition, C allele of the T102C was found to represent a risk factor for depressed patients to attempt suicide (Arias et al., 2001).

In summary, the involvement of 5- $\mathrm{HT}_{2 \mathrm{~A}}$ receptor in the enactment of aggressive and impulsive responses remains poorly understood, in view of experimental limitations (such as the lack of highly selective $5-\mathrm{HT}_{2 \mathrm{~A}}$ receptor agonists for experimental studies) and differential roles played by these post-synaptic targets across different brain regions. It is likely that regional subpopulations of 5- $\mathrm{HT}_{2 \mathrm{~A}}$ receptors (such as those in the PFC and OFC) may participate in the emotional and cognitive appraisal of environmental triggers for aggressive and suicidal responses, and thus help convey some of the neurochemical signals related to the ideation, planning, initiation, execution and extinction of IABs. The diverse contributions of these regional subgroups of $5-\mathrm{HT}_{2 \mathrm{~A}}$ receptors may explain the associations between HTR2A variants and different aspects of aggression and suicidal behaviours. However, further studies on the functional significance of the different clusters of 5- $\mathrm{HT}_{2 \mathrm{~A}}$ receptors are needed to define the specific relevance of these targets in IABs and suiciderelated traits, as well as the comorbid emotional disturbances associated with aggression.

2.3.2 5- $\mathrm{HT}_{2 \mathrm{C}}$ receptors - In contrast with the other major 5-HT receptors, the role of 5$\mathrm{HT}_{2 \mathrm{C}}$ receptors in aggression has long remained elusive, and has been investigated only recently, thanks to the development of novel selective ligands. The few data currently available indicate that stimulation of these targets reduces aggressive responses and enhances the display of submissive behaviour (Dekeyne et al., 2012; Harvey et al., 2012; Rosenzweig-Lipson et al., 2007). These effects, however, may result from a general enhancement in social anxiety (Kantor et al., 2000). The possible implication of 5- $\mathrm{HT}_{2 \mathrm{C}}$ receptor in suicidal behaviours has been studied in genetic association analyses. The gene that codes this receptor (HTR2C) is located at position Xq24 (Milatovich et al., 1992) and consists of six exons and five introns (Xie et al., 1996) (Table 1). According to NCBI SNP Database, there are several thousand SNP within HTR2C. Among them, the bestcharacterized one is the polymorphism Cys23Ser (rs6318), consisting of two variants, C and $\mathrm{G}$ and resulting in the change of the amino acid Cysteine into Serine in the N-terminal region of the protein. Of note, $5-\mathrm{HT}_{2 \mathrm{C}}$ is altered post-transcriptionally, and differences in pre-mRNA editing of $5-\mathrm{HT}_{2 \mathrm{C}}$ receptors were found between control subjects and suicidal victims (Dracheva et al., 2008; Gurevich et al., 2002). In contrast, most studies failed to identify significant associations among polymorphisms of this receptor and suicidal attempts (Arias et al., 2001; Serretti et al., 2009; Serretti et al., 2007; Turecki et al., 2003; Zhang et al., 2008), completed suicide (Stefulj et al., 2004), the severity of suicidal behaviours (De Luca et al., 2008b; Di Giovanni et al., 2011) or suicide risk and deliberate self-harm (Pooley et al., 2003). To the best of our knowledge, only one study detected a significant association between completed suicide and the variants of the SNP rs6318, with the excess of GG genotype and allele $\mathrm{G}$ in suicide victims (Videtic et al., 2009).

\subsection{The role of other 5-HT receptors in aggression and suicide}

2.4.1. 5- $\mathrm{HT}_{3}$ receptors - In contrast with the other 5-HT receptors, $5-\mathrm{HT}_{3}$ is a pentameric, ion-gated channel that mediates fast synaptic transmission. In the CNS these receptors are located in many areas relevant to emotional regulation, including the neocortex, amygdala, hippocampus, nucleus accumbens and brainstem. Of the five subunits identified to date, termed 5- $\mathrm{HT}_{3 \mathrm{~A}}$ to $5-\mathrm{HT}_{3 \mathrm{E}}$, only the first two (A and $\mathrm{B}$ ) have been sufficiently characterized. Several preclinical experiments have shown that $5-\mathrm{HT}_{3}$ receptors exert a complex influence on aggressive responses in rodents. For example, pharmacological tests suggests that these receptors participate in alcohol-and cocaine-induced aggression (Ricci et al, 2004; McKenzie-Quirk et al, 2005). In general, several 5-HT 3 antagonists have been shown to reduce aggression in a fashion dependent on the genetic background and the 
baseline proclivity to engage in fighting behaviour (McKenzie-Quirk et al, 2005; Cervantes et al, 2010). Conversely, other lines of evidence indicate that these compounds are often inefficacious in affecting isolation-induced aggression (White et al, 1991; Sanchez et al, 1993). Notably, 5-HT 3 agonists have also been shown to exert anti-aggressive properties in some (Poncelet et al, 1995; Rudissaar et al, 1999), but not all studies (Ricci et al, 2005).

In contrast with the rich associations between $5-\mathrm{HT}_{3}$ receptors and aggression, their possible involvement in suicidal behaviour has been challenged by genetic association studies (Souza et al, 2011) and post-mortem assessments of their binding in the cortex of suicide victims (Mann et al, 1996).

2.4.2 5- $\mathrm{HT}_{4}, 5-\mathrm{HT}_{6}$ and 5- $\mathrm{HT}_{7}$ receptors-Our current knowledge on the 5-HT receptors coupled to Gs proteins $\left(5-\mathrm{HT}_{4}, 5-\mathrm{HT}_{6}\right.$ and $\left.5-\mathrm{HT}_{7}\right)$ with respect to the modulation of aggression and suicide is still rudimentary. Initial studies appear to implicate a significant up-regulation of 5- $\mathrm{HT}_{4}$ receptors in the frontal cortex and caudate nucleus of depressed suicide victims (Rosel et al, 2004). Studies on the C267T polymorphism of the human 5HT6 gene have shown a possible implication of this SNP in suicide of male patients (Azenha et al, 2009; but see Okamura et al, 2005 for contrasting findings). The same SNP was not found in association with aggressive behaviour in schizophrenia patients (Tsai et al, 1999). Although the role of 5-HT7 in aggression and suicidal behaviour remains elusive, preliminary pharmacological studies appear to temper the possibility of a direct implication of this target in the modulation of aggression (Navarro et al, 2004).

\subsection{The role of TPH in aggression and suicide}

The synthesis of 5-HT depends on the specific action and rate-limiting step of the enzyme 1tryptophan-5-monooxygenase (EC 1.14.16.4), commonly termed tryptophan hydroxylase (TPH). A member of the aromatic amino acid hydroxylases (AAAH) family, TPH converts tryptophan to 5-hydroxytryptophan (5-HTP) using molecular oxygen, ascorbic acid, and biopterin. The two TPH isoenzymes known to date, $\mathrm{TPH}_{1}$ and $\mathrm{TPH}_{2}$ (Walther et al., 2003), are respectively encoded by genes located on chromosome 11 and 12 in humans. Although the two enzymes share considerable sequence identity, their regulatory domains differ substantially (Murphy et al., 2008b). As far as their anatomical distribution is concerned, $\mathrm{TPH}_{1}$ is expressed mostly in peripheral tissues (with the exception of the pineal gland) while $\mathrm{TPH}_{2}$ is predominant in the CNS, and typically expressed in the raphe nuclei as well as the brain areas targeted by 5 -HTergic projections (Carkaci-Salli et al., 2011) (Table 3). The Km of partially purified TPH for tryptophan is approximately $30-60 \mu \mathrm{M}$. Considering the brain concentrations of tryptophan, TPH is not expected to be saturated with substrate, and the formation of 5-HT in brain is predicted to rise as the brain concentration of tryptophan increases (Leathwood and Fernstrom, 1990). Unfortunately, tryptophan-rich diets produce a simultaneous increase of peripheral 5-HT, with important side effects. On the contrary, selective targeting of $\mathrm{TPH}_{2}$ can selectively boost the synthesis of 5-HT in the brain, increasing the stored amount and evoked release of the neurotransmitter; this pharmacological strategy may be highly promising for the development of novel antidepressants (Torrente et al., 2012). The product of TPH-mediated reaction, 5-HTP, is decarboxylated into 5-HT by L-aromatic amino acid decarboxylase (AADC) (EC 4.1.1.28). Interestingly, AADC catalyzes the decarboxylation of both 5-HTP and 3,4dihydroxyphenylalanine (DOPA) in catecholaminergic neurons. The gene encoding the enzyme is referred to as dopa decarboxylase (DDC), and located on chromosome 7 in humans (Scherer et al., 1992). Almost 30 genetic mutations of $D D C$ have been characterized in patients with AADC deficiency (Haavik et al., 2008). 
Both clinical and preclinical evidence indicate that Impulsive-aggressive behaviours and other aggressive phenotypes are modulated by both TPH isoenzymes. In laboratory animals, acute pharmacological inhibition of TPH typically enhances inter-male aggression by reducing 5-HT levels (Vergnes et al., 1986). Because of its role as the rate-limiting enzyme of 5-HT biosynthesis, TPH expression and activity are normally affected by chronic exposure to environmental conditions that facilitate or reduce aggression, such as repeated victory or defeat (Amstislavskaya and Kudryavtseva, 1997), or by genetic selection for aggressiveness or docility (Popova et al., 1991). In line with the general variability observed across most 5-HT targets, the heterogeneity of these variations documented by different studies is likely to signify that changes in TPH may reflect compensatory adaptive mechanisms probably aimed at restoring 5-HT homeostasis. Notably, mice hypomorphic or deficient in TPH2 were recently reported to exhibit high aggression, as well as other emotional alterations (Beaulieu et al., 2008; Mosienko et al., 2012). In contrast, the G allele of the murine $\mathrm{C} 1473 \mathrm{G}$ polymorphism was found to be associated to lower TPH2 activity in the midbrain (Kulikov et al., 2005), as well as lower aggression and reduced depression-like behaviour in the forced swim test (Kulikov et al., 2005; Osipova et al., 2009).

Most clinical studies have been focused on genetic associations between SNP variants of the TPH1 gene and several indices of aggressive personality or prevalence of suicidal behaviour. For example, the $\mathrm{L}$ allele of the A218C polymorphism located in intron 7 of TPH1 was associated with higher Buss-Durkee Hostility Inventory (BDHI) scores (New et al., 1998), and occurred with higher frequency in violent males (Nolan et al., 2000). Subsequent analyses, however, found that carriers of the $\mathrm{U}$ allele had a greater tendency to express their anger outwardly, and experience unprovoked anger (Manuck et al., 1999). The same genotype was found to be associated with impulsive behavioural tendencies (IBTs) (Staner et al., 2002) and anger-related traits (Rujescu et al., 2002).

The A779C polymorphism was found to be significantly related to aggressive hostility, with the highest aggression levels for the genotype AA and the lowest aggression levels for the genotype CC in volunteers (Hennig et al., 2005). Conversely, another study on Korean individuals found that $\mathrm{CC}$ homozygotes in the major depression disorder group scored significantly higher in terms of verbal aggression and total aggression than A carrier genotypes, regardless of sex and age (Koh et al., 2012).

Several post-mortem studies have found an increased expression of TPH2 mRNA (BachMizrachi et al., 2008; Bach-Mizrachi et al., 2006; Perroud et al., 2010) and higher levels of the TPH2 protein (Boldrini et al., 2005; Bonkale et al., 2006; Underwood et al., 1999) in the brain of depressed suicide victims. Bach-Mizarchi et al. (Bach-Mizrachi et al., 2008) proposed that a higher TPH2 expression could be a response to deficient 5-HT levels in the brains of depressed suicides.

The human TPH2 gene covers about $93.5 \mathrm{~kb}$, consists of 11 exons, and exhibits hundreds of SNPs and multiple post-translational modifications (Zhang et al., 2006). Most of the detected sequence variants in $T P H 2$ gene are SNPs, mainly located in noncoding regions of the gene. In the association and linkage disequilibrium study on suicide victims, evaluating 10 SNPs in the TPH2, a significant association between SNP rs1386494 in intron 5 and suicide was found (Zill et al., 2004). A haplotype analysis showed a significant association with suicide for three haplotypes (Zill et al., 2004). This result could not be replicated by Lopez de Lara et al. (Lopez de Lara et al., 2007). These last authors (Lopez de Lara et al., 2007) investigated 14 SNPs (9 intronic, 2 exonic and 3 SNPs in the 5' upstream region of the gene). They found a significant overrepresentation of alleles T, G, G and C of the SNPs rs4448731 (TPH2 upstream region), rs6582071 (TPH2 upstream region), rs4641527 (intron 1), and rs1386497 (intron 8), respectively, in depressed suicide completers. No association 
was found regarding functional SNP G1463A (rs120074175) in exon 11 (Lopez de Lara et al., 2007), similarly to the findings of other studies (Delorme et al., 2006; Garriock et al., 2005). Results obtained for rs6582071 were not confirmed by other studies (Mouri et al., 2009; Must et al., 2009). Most of the studies that have focused on the SNPs placed in the TPH2 upstream region, that has an impact on protein expression, relate to rs 4570625 (located in the promoter region of the gene). Yoon et al. (Yoon and Kim, 2009) showed a positive association of rs 4570625 with suicide attempt and concluded that the observed increased frequency of $\mathrm{G}$ allele may be associated with elevated suicidal behaviour. Several other studies, however, did not confirm this association (Mouri et al., 2009; Stefulj et al., 2011; Zhou et al., 2005; Zill et al., 2007). The human TPH2 promoter polymorphism rs 11178997 is another SNP in the promotor region that has an impact on TPH2 expression (Chen et al., 2008), but according to results obtained by several different groups (De Luca et al., 2005b; Lopez et al., 2007; Must et al., 2009; Zhou et al., 2005), it has no impact on suicide attempt and completion. SNP rs7305115, which is located at approximately $1077 \mathrm{bp}$ from the 7 exon, could be involved in the control of TPH2 mRNA expression (Lim et al., 2007) and it could also influence suicidal behaviour (Ke et al., 2006; Zhang et al., 2010). Grohmann et al. (Grohmann et al., 2010) reported a higher frequency of rs4290270 AA genotype in suicide completers and found evidence that rs 4290270 affects $T P H 2$ alternative splicing and editing. TPH2 SNP variants have also been recently associated with the association of affective lability, aggression and suicidal behaviour (Perez-Rodriguez et al., 2010).

Taken together, emerging evidence suggests that TPH2 may have a direct implication on the pathophysiology of IABs and other aspects of aggression and suicidality. However, evidence in this respect is still preliminary and awaits more thorough characterization by means of selective inhibitors and brain-regional infusion studies in animal models, as well as studies on potential associations between its as-yet poorly examined SNPs, and specific endophenotypes of aggression (also in association to environmental triggers and genderspecific factors).

\subsection{The role of $5-\mathrm{HTT}$ in aggression and suicide}

The extracellular levels of 5-HT are regulated by 5-HTT, both in central and peripheral 5HT-ergic subsystems (Lesch et al., 1993b). The human gene for 5-HTT, termed SLC6A4, is located in the chromosome 17, and codes a protein comprised of 630 amino acids with 12 transmembrane domains (Lesch et al., 1993a; Mayser et al., 1991). 5-HTT is localized on the terminals of 5-HT neurons, where it ensures the recapture of 5-HT. It is the pharmacological target of selective reuptake inhibitors (SSRIs) mainly used as antidepressants (Geddes et al., 2000).

The implication of 5-HTT in the regulation of aggressive behaviour is cogently indicated by the well-documented anti-aggressive effects of SSRIs, both in psychiatric patients and healthy volunteers (Barkan et al., 2006; Blader, 2006; Bond, 2005; Carrillo et al., 2009; Coccaro et al., 1997; Reist et al., 2003; Walsh and Dinan, 2001). Similarly to the time-frame of the antidepressant effects of these agents, their antiaggressive potential is generally observed only following prolonged treatment ( $2-3$ weeks), likely as a result of neuroplastic adaptive mechanisms resulting in receptor desensitization or synaptic remodelling. Chronic SSRI administration has been shown to restore the metabolic activity of the PFC (New et al., 2004), suggesting that the reduction in aggression induced by these compounds may depend on the integrity of prefrontal function, which is essential for impulse control as well as emotional appraisal of social contexts. In support of this possibility, Troisi and colleagues (Troisi et al., 1995) documented that, in a subset of patients affected by mental retardation and epilepsy, chronic treatment with fluoxetine led to enhanced, rather than reduced aggressiveness. 
The evidence on the effects of SSRIs on aggression is generally paralleled by findings in rodents (Carrillo et al., 2009; Delville et al., 1996; Olivier et al., 1989; Pinna et al., 2003). However, a critical difference between the effects of SSRIs in humans and most rodent models of aggression is that, in the latter, the ameliorative effects of these compounds is already significant after acute administration, and sometimes even reversed after chronic treatment (Mitchell, 2005; Mitchell et al., 1991; Mitchell and Redfern, 1992). While the neurochemical underpinnings of these phenomena remain poorly understood, these divergent findings may reflect the intrinsic limitations of the experimental manipulations used to elicit aggressive reactions in rodents, such as social isolation (which may lead to enhanced territorial behaviour and instrumental aggression).

Notably, genetic deficiency of 5-HTT in mice results in lower levels of aggression in the resident-intruder paradigm, with longer latency to the first attack and fewer fighting encounters, but no changes in social investigations (Holmes et al., 2002). 5-HTT KO mice display lower 5-HT reuptake and higher 5-HT forebrain concentrations compared to wildtype (WT) conspecifics (Mathews et al., 2004). In addition, these mutants exhibit improved inhibitory control (Homberg et al., 2007) and are less likely to obtain a dominant status in comparison with WT mice. In this respect, it is worth noting that the levels of aggression shown by 5-HTT KO mice are greatly influenced by the opponent's behaviour, as well as the venue of the aggressive encounter (Jansen et al., 2011).

While few authors have investigated platelet 5-HTT binding as a potential biomarker of aggression with variable results (Barkan et al., 2006; Coccaro et al., 2010), recent studies have shown higher 5-HTT binding in the brainstem in impulsive and aggressive humans (Rylands et al., 2012) and rats (Kerman et al., 2011), suggesting that this index may be a valuable cross-species parameter for translational studies.

The role of 5-HTT in the modulation of aggression is also strongly supported by several genetic studies on $S L C 6 A 4$ polymorphic variants. SLC6A4 is among the most frequently studied candidate genes for psychiatric disorders and suicidal behaviour (Lesch and Gutknecht, 2005). The best-characterized polymorphism of 5-HTT is 5-HTTLPR (5-HTTlinked promoter region), a 43-bp insertion/deletion variation within the promoter region, which is thought to regulate variations in transcriptional activity: the long variant ( $\mathrm{L}$ allele, with 16 repeats) has higher basal activity and expression than the short variant ( $\mathrm{S}$ allele, with 14 repeats) (Heils et al., 1996; Lesch et al., 1996). Another recently detected SNP (rs25531) consisting in an $\mathrm{A} \rightarrow \mathrm{G}$ substitution in the 6th motif upstream the 5-HTTLPR locus, has been shown to influence the binding for Activator Protein-2 (AP2), a transcriptional suppressor of the 5-HTT (Kraft et al., 2005). The G allele of the rs25531 is associated with low level of 5-HTT mRNA expression, which makes it similar to allele $\mathrm{S}$ of the 5-HTTLPR, while the A allele is associated with high level of mRNA expression (Hu et al., 2006), which is similar to allele $\mathrm{L}$ of the 5-HTTLPR. Therefore, more recent studies analyze 5-HTTLPR and rs25531 as a triallelic system (Bozina et al., 2012; De Luca et al., 2008a), in which $\mathrm{L}_{\mathrm{A}}$ allele (allele L with rs25531 A variant) is associated with high 5-HTT functionality, while the $\mathrm{S}$ and $\mathrm{L}_{\mathrm{G}}$ (L allele with $\mathrm{rs} 25531 \mathrm{G}$ variant) alleles are linked to lower 5-HTT expression (Bozina et al., 2012; Hu et al., 2006; Zalsman et al., 2006).

Most genetic studies have pointed to an association between the S haplotype of 5-HTTLPR and the prevalence or severity of several emotional disturbances, encompassing anxiety, depression, impulsivity, hostility, anger, novelty-seeking behaviour and worse therapeutic responsiveness to SSRIs (Courtet et al., 2001; Evans et al., 1997; Gerra et al., 2005; Hallikainen et al., 1999; Lesch and Merschdorf, 2000; Silva et al., 2010). The same variant has been linked to aggressive reactivity in children and conduct disorder in adolescents (Beitchman et al., 2006; Haberstick et al., 2006; Sakai et al., 2006). In addition, the presence 
of one or two S alleles of 5-HTTLPR has been associated with most suicidal behaviours, including violent suicide (Bellivier et al., 2000; Bondy et al., 2006; Campi-Azevedo et al., 2003; Li and He, 2007), violent or impulsive suicide attempts (Baca-Garcia et al., 2005; Neves et al., 2010; Neves et al., 2008) re-attempted suicidal attempts (Courtet et al., 2004), suicide attempts in abused children (Gibb et al., 2006), suicide attempts with high medical damage (Wasserman et al., 2007), and a life-time risk of suicide attempts in male subjects (Limosin et al., 2005).

Nevertheless, other studies found no significant association between 5-HTTLPR and suicidal attempts (Akar et al., 2010; Bah et al., 2008; Chen et al., 2007; De Luca et al., 2008a; De Luca et al., 2006; De Luca et al., 2005b; Gerra et al., 2004; Roy et al., 2007; Shen et al., 2004; Zalsman et al., 2006), suicide history (Malloy-Diniz et al., 2011; Yen et al., 2003), family history of suicidal behaviour (Correa et al., 2004), severity of suicidal attempt (De Luca et al., 2005b) or completed suicide in suicidal victims (Mann et al., 2000; Pungercic et al., 2006). The lack of significant association between suicide attempt or ideation and 5-HTTLPR was confirmed in the large European multicenter case-control (Mendlewicz et al., 2004), or twin sample (Coventry et al., 2010), evaluating both bilalleic (5-HTTLPR) and triallelic (5-HTTLPR + rs25531) classification (Coventry et al., 2010; De Luca et al., 2006).

These discrepancies might be partially explained by the numerous methodological issues such as lack of statistical power, differences in the diagnostic criteria and inclusion of patients with different psychiatric diagnoses and healthy control subjects and different severity of suicidal behaviour (ranging from suicidal ideation to completed suicide). In addition, studies evaluating biallelic 5-HTTLPR classifications may yield different results from those using triallelic models (Bozina et al., 2012).

An alternative explanation for the numerous discrepancies in association studies may lie in the possibility that multiple biological and environmental factors may moderate the relation between 5-HTTLPR and suicide or aggression. For example, Cadoret and co-workers (Cadoret et al., 2003) have suggested that, in contrast with males, female carriers of short variants display lower levels of conduct disorder and aggressiveness. On the other hand, the LL genotype was also significantly associated with suicide attempts in women, but not in men (Gaysina et al., 2006).

Ethnic (Noskova et al., 2008) and/or socio-cultural components may also differentially influence the association of 5-HTLLPR polymorphic variations and aggression; for example, no significant correlation was identified in groups of African-Americans (Patkar et al., 2002) or Spanish suicide attempters (Baca-Garcia et al., 2004), and only a marginal association between the s variant and aggressiveness was found in Korean schizophrenia patients (Kim et al., 2009).

Additional lines of research suggest that the relevance of 5-HTLLPR with respect to aggression may be related to specific gene $\times$ environment interactions; for example, carriers of the short-allele variant were found to exhibit greater proclivity to aggression and suicidal ideation in response to stressful events (Caspi et al., 2003; Conway et al., 2012; Verona et al., 2006). These data may suggest that 5-HTT genotype may exert a direct influence on cognitive and emotional modalities of stress-coping, which may result in increased aggression, poor impulse control and suicidal tendencies in the presence of unfavourable psychosocial contingencies. Thus, the association between the $S$ variant and aggression may depend on the function of the prefrontal cortex, in a fashion similar to what could be postulated for the therapeutic effects of SSRIs. Accordingly, several studies have shown that, in Alzheimer's disease patients or individuals with intellectual disabilities, aggression 
is associated with the long allelic variant, rather than the short one (May et al., 2010; Sukonick et al., 2001; Sweet et al., 2001).

A VNTR polymorphism has been found in intron 2 of the 5-HTT, containing 9, 10 or 12 copies of a 17-bp repeat element. It is assumed that the transcriptional regulatory activity depends on the number of repeat copies; thus, the 12-repeat allele has higher activity than the 10- and the 9-alleles (Fiskerstrand et al., 1999; MacKenzie and Quinn, 1999). The association between 5-HTT VNTR intron 2 and suicide has been investigated (Bah et al., 2008; Bellivier et al., 2000; De Luca et al., 2007; De Luca et al., 2006; De Luca et al., 2005a; Gaysina et al., 2006; Ho et al., 2001; Hranilovic et al., 2003; Jernej et al., 2004; Lopez de Lara et al., 2007; Pungercic et al., 2006; Shen et al., 2004; Yen et al., 2003), yielding mixed results. Whereas one study found a protective effect of the 10-repeat allele against suicidal behaviour and an association of this variant with lower suicidal scores in schizophrenic patients (De Luca et al., 2006), another report documented that the same allele was more common among depressed suicide attempters (Lopez de Lara et al., 2007).

\subsection{The role of MAO $A$ in aggression and suicide}

Monoamine oxidases (MAOs; E.C. 1.4.3.4) are flavin-adenosine-dinucleotide (FAD)containing enzymes that catalyze the degradation of biogenic amines. The two MAO isoforms, termed MAO-A and MAO-B, differ in molecular weight (527 and 520 amino acid, respectively), inhibitor sensitivities and substrate affinities: while MAO-A prefers 5-HT, norepinephrine and epinephrine, MAO-B has a high affinity for $\beta$-phenylethylamine. In most vertebrate species, dopamine metabolism is served by both forms. Both MAOs are coded by genes located in the $\mathrm{X}$ chromosome, but are transferred to the outer mitochondrial membrane. The distribution patterns of MAOs in the organism are also strikingly divergent. Within the central nervous system, MAO-B is expressed at highest levels in the cell bodies of 5-HT-ergic neurons, histaminergic neurons and glial cells, while MAO-A is primarily expressed in catecholaminergic neurons (Jahng et al., 1997; Luque et al., 1995; Saura et al., 1994; Westlund et al., 1988). In the peripheral tissues, MAO-A is particularly abundant in the placenta (Egashira and Yamanaka, 1981), liver, and gastro-intestinal tract, while MAO$\mathrm{B}$ is the only isoform expressed in platelets and lymphocytes (Bond and Cundall, 1977). Human MAO-A and MAO-B show 70\% homology in amino acid sequence (Chen and Shih, 1998).

Multiple lines of evidence have indicated that MAO-A deficiency leads to impulsive aggression in animals and humans. The nonsense mutation of $M A O A$ gene results in Brunner syndrome, a X-linked condition characterized by marked proclivity to engage in violent and antisocial behaviours (including attempted rape, murder and arson) in response to relatively minor stressors, as well as borderline mental retardation, stereotyped hand movements and sleep disturbances. These behavioural abnormalities are accompanied by high 5-HT and low urinary 5-HIAA concentrations (Brunner et al., 1993a; Brunner et al., 1993b). The symptoms of Brunner syndrome are strikingly similar to the aberrant phenotypes of MAO-A KO mice (Cases et al., 1995; Scott et al., 2008). In these animals, MAO-A deficiency leads to high levels of brain 5-HT and norepinephrine (NE), as well as a spectrum of abnormal behavioural responses, including high levels of inter-male aggression (Bortolato and Shih, 2011; Cases et al., 1995; Scott et al., 2008), social and communication deficits (Bortolato et al., 2012a), poor exploratory behaviour towards novel contexts and objects (Godar et al., 2011), reduced depression-like responses (Cases et al., 1995), greater retention of aversive memories (Dubrovina et al., 2006; Kim et al., 1997), reduced risk assessment and maladaptive stress reactivity (Godar et al., 2011; Popova et al., 2001), repeated and perseverative responses as well as low learning reversal (Bortolato et al., 2012a). While the neurobiological bases of the behavioural changes observed in MAO-A KO mice are still incompletely understood, several findings suggest that they may be 
underpinned by early developmental mechanisms. In fact, chronic pharmacological MAO-A inhibition in adult rodents does not result in aggressiveness, but rather in decreased defensive behaviour (Griebel et al., 1998), enhanced exploratory activity (Steckler et al., 2001) and reduced aggression (Isel et al., 1988). Conversely, treatment with the MAO-A selective inhibitor clorgyline and other MAO inhibitors induces behavioural alterations similar to those documented in MAO-A KO mice (Mejia et al., 2002; Whitaker-Azmitia et al., 1994). Recent studies have also shown that the overt aggression exhibited by MAO-A KO mice reflects alterations in the composition and biophysical properties of NMDA glutamate receptors of the prefrontal cortex (Bortolato et al., 2012b). This finding is particularly interesting in consideration of the key role of this region in the emotional appraisal of social and environmental contexts, as well as the well-documented function of NMDA receptors in information processing.

In addition to the characterization of Brunner syndrome, abundant clinical evidence on the role of MAO-A in aggression has come from genetic studies of the functional polymorphisms of $M A O A$ gene and its promoters. In particular, the $M A O A-\mathrm{uVNTR}$, a 30bp VNTR polymorphism located $1.2 \mathrm{~kb}$ upstream of the MAO-A coding sequence (Sabol et al., 1998), has been associated with different levels of transcriptional activity of the MAOA gene. Of the six MAOA-uVNTR variants characterized to date (with 2, 3, 3.5, 4 and 5 repeats) (Huang et al., 2004a), the 3-repeat and 4-repeat (4R) alleles have been respectively associated to lower and higher transcriptional efficiency and catalytic activity (Deckert et al., 1999; Denney et al., 1999; Sabol et al., 1998).

In several studies, the $3 \mathrm{R}$ variant has been repeatedly associated with antisocial personality, maladaptive responsiveness to stress, deficits in affective processing and lower cognitive functioning (Brummett et al., 2008; Buckholtz and Meyer-Lindenberg, 2008; Cohen et al., 2003; Contini et al., 2006; Oreland et al., 2007; Samochowiec et al., 1999; Williams et al., 2009); but see (Koller et al., 2003) for contrasting results).

Notably, the link between genotypes and aggression has been recently found to be dependent on a gene $\times$ environment interaction, with male $3 \mathrm{R}$-carriers developing aggressive behaviour only when they had a history of abuse and neglect during childhood (Caspi et al., 2002; Edwards et al., 2010; Foley et al., 2004; Frazzetto et al., 2007; Huang et al., 2004b; Kim-Cohen et al., 2006; Weder et al., 2009).

Functional brain imaging studies have shown that, in males, the $3 \mathrm{R}$ variant is associated with changes in the volume of OFC, as well as hyperreactivity of amygdala and hippocampus during aversive recall (Meyer-Lindenberg et al., 2006). These findings have led Buckholtz and Meyer-Lindenberg (Buckholtz and Meyer-Lindenberg, 2008) to theorize that the 3R haplotype may interfere with the ontogenesis of the prefrontal cortex and other regions of the corticolimbic circuit, facilitating the emergence of negative socio-cognitive bias. In support of this hypothesis, Eisenberger and colleagues (Eisenberger et al., 2007) showed that low-activity variants may enhance the sensitivity of negative social experiences like social rejection. Thus, it is likely that early traumatic experiences, in association with low-activity MAO-A variants, may result in persistent alterations of socio-emotional appraisal, which could facilitate the insurgence of aggressive responses, particularly in the presence of high-provocation contingencies (McDermott et al., 2009) and threat-related situations (Williams et al., 2009).

The association between $M A O A$-uVNTR variants and MAO-A brain activity has been challenged by post-mortem (Balciuniene et al., 2002) and PET studies (Fowler et al., 2007); however, self-reported aggression in men was found to be inversely correlated to the brain activity of MAO-A irrespective of the genotype (Alia-Klein et al., 2008). Collectively, these 
lines of evidence suggest that polymorphic variants may confer higher or lower "baseline" MAO-A activity levels during early life stages (critical for the development of corticolimbic circuitry); however, enzymatic function may be subsequently altered by a broad set of environmental elements throughout life (Bortolato and Shih, 2011).

The majority of association studies have failed to detected a significant correlation between $M A O A$-uVNTR variants and suicidal behaviour [(De Luca et al., 2008a; De Luca et al., 2006; De Luca et al., 2005a; Hung et al., 2012; Kunugi et al., 1999; Ono et al., 2002); but see (Lung et al., 2011) for contrasting evidence]. Nevertheless, one study has indicated that the frequency of $2 \mathrm{R}$ and $3 \mathrm{R}$ alleles is significantly higher in men who had attempted suicide by violent means compared to men who had committed suicide by non-violent means (Courtet et al., 2005); this finding suggests that the endophenotype associated with low MAO-A activity may only affect the modality of execution, rather than the intention of suicidal actions.

Other functional polymorphisms, Fnu 4HI and Eco RV, have also been investigated for the association with aggression and suicide. Ho et al. (Ho et al., 2000) reported an association of the FnuHI allele 1 - which is responsible for the lower activity of MAO-A (Hotamisligil and Breakefield, 1991) - with a history of suicide attempts in female bipolar patients.

Conversely, Du et al. (Du et al., 2000) found a significant association between high-activity related allele (allele 2) and suicide in depressed male suicide victims. The significance of these findings awaits further studies to be clarified.

\section{CONCLUSIONS AND RESEARCH DIRECTIONS}

The evidence overviewed in the previous sections, albeit fraught with inconsistent results, is in support of a pivotal role of 5-HT-ergic system (and its multiple molecular components) in the pathophysiology of IABs and other intermediate phenotypes underlying the association between reactive aggression and suicide (such as negative bias in the interpretation of ambiguous social cues, deficits in social recognition etc.). In particular, recent studies underscored that, while alterations in 5-HT-ergic homeostasis may signal different degrees of vulnerability to violent aggressiveness and suicidal behaviours, their translation into pathological conditions occurs only in the presence of other critical environmental and gender-related variables. The convergence of these factors is posited to lead to enduring abnormalities of the socio-affective scaffolding (with respect to the connectivity between prefrontal cortex, limbic areas and raphé nuclei), which may ultimately result in higher proclivity to exhibit violent outbursts and engage in self-harmful behaviours in response to psychosocial stress or other contextual triggers.

One of the most important limitations in human studies, particularly in suicide completers, lies in the intrinsic difficulty in recognizing the distinctive contribution of diverse psychological characteristics (and their neurochemical correlates) to multifaceted behavioural phenomena such as aggression and suicidality. The pursuit of this critical goal would enable to distinguish "neurobiological signatures" relevant to IABs from complex profiles of 5-HT-ergic dysfunctions that may reflect the influence of comorbid disturbances, such as depression or anxiety.

On the other hand, the the translational value of most animal studies on the neurobiological relationship between aggression and suicidal conducts is greatly limited by the lack of suicidal activity in animal models, as well as the relatively poor characterization of the differences between reactive and proactive elements of aggression in experimental preparations. The refinement of ethological criteria to distinguish diverse subtypes of aggression in 
The acknowledgment of the critical importance of gene $\times$ environment $\times$ gender interactions in aggression promises to lead to the development of new, highly isomorphic animal models of this disorder. Current translational perspectives call for a greater interface between these innovative experimental strategies and genetic association studies with more refined assessment criteria. It is expected that the combination of this perspective with complementary epigenetic, transcriptomic, proteomic and brain-imaging approaches will help develop a heuristic translational platform to identify reliable biomarkers for the early diagnosis and prevention of reactive aggression and suicidal behaviours.

\section{Acknowledgments}

The authors are indebted to the EU COST Action CM1103 "Structure-based drug design for diagnosis and treatment of neurological diseases: dissecting and modulating complex function in the monoaminergic systems of the brain" for supporting their international collaboration. The work was also supported by the grant R21HD070611 (to MB), from the U.S. National Institute of Health, the University of Malta Funding Scheme (GDi G), by the Croatian Ministry of Science, Education and Sport, grants numbers 098-0982522-2455 (NP) and 098-0982522-2457 (DMS) and by COMPAGNIA di San Paolo (Turin) "Programma Neuroscienze" (MP), Telethon GGP11188 (MP), and Fondazione Cassa di Risparmio di Perugia (MP).

\section{ABBREVIATIONS}

5-HIAA

5-HT

5-HTT

5-HTTLPR

АААН

AADC

AP2

BDHI

CB

CNS

DDC

DGGE

DOPA

DRN

EPSPs

FAD

GI

His

IAB

IBTs

INS/DEL

IPSP

ir 5-hydroxyindoleacetic acid

5-hydroxytryptamine

5-HT transporter

5-HTT-linked promoter region

aromatic amino acid hydroxylase

L-aromatic amino acid decarboxylase

Activator Protein-2

Buss-Durkee Hostility Inventory

calbindin

central nervous system

dopa decarboxylase

denaturing gradient gel electrophoresis

3,4-dihydroxyphenylalanine

dorsal raphe nucleus

excitatory postsynaptic potentials

flavin-adenosine-dinucleotide

gastrointestinal

hystidine

Impulsive-aggressive behaviours

Impulsive behavioural tendencies

insertion/deletion

inhibitory postsynaptic potentials

immunoreactive 


\begin{tabular}{ll} 
KO & knockout \\
MAO & Monoamine oxidase \\
mPFC & medial prefrontal cortex \\
MRN & median raphe nucleus \\
NAc & nucleus accumbens \\
NMDA & N-methyl-Daspartate \\
NPY & neuropeptide Y \\
NRM & nucleus raphe magnus \\
NRO & nucleus raphe obscurus \\
NRP & nucleus raphe pallidus \\
NUDR/Deaf-1 & nuclear deformed epidermal autoregulatory factor-1 \\
OFC & orbitofrontal cortex \\
PAG & periaqueductal gray \\
PET & positron emission tomography \\
PV & parvalbumin \\
SNPs & single nucleotide polymorphisms \\
SSRIs & serotonin selective reuptake blockers \\
TPH & tryptophan hydroxylase \\
Tyr & tyrosine \\
VNTR & variable number tandem repeat \\
VTA & ventral tegmental area \\
WT & wild-type \\
\hline
\end{tabular}

\section{REFERENCES}

Abrams JK, Johnson PL, Hollis JH, Lowry CA. Anatomic and functional topography of the dorsal raphe nucleus. Ann N Y Acad Sci. 2004; 1018:46-57. [PubMed: 15240351]

Aghajanian, G.; Sanders-Bush, E. Electrophysiology of serotonin receptor subtypes and signal transduction pathways. In: Bloom, FR.; Kupfer, DJ., editors. Neuropsychopharmacology: The Fifth Generation of Progress. Lippincott Williams \& Wilkins; 2002. p. 15-34.

Akar T, Sayin A, Bakkaloglu Z, Cabuk DK, Kucukyildirim S, Demirel B, Candansayar S, Ozsoy ED, Mergen H. Investigation of serotonin transporter gene promoter (5-HTTLPR) and intron 2 (variable number of tandem repeats) polymorphisms with suicidal behavior in a Turkish population. DNA Cell Biol. 2010; 29:429-434. [PubMed: 20438360]

Albert PR, Francois BL. Modifying 5-HT1A Receptor Gene Expression as a New Target for Antidepressant Therapy. Front Neurosci. 2010; 4:35. [PubMed: 20661455]

Alia-Klein N, Goldstein RZ, Kriplani A, Logan J, Tomasi D, Williams B, Telang F, Shumay E, Biegon A, Craig IW, Henn F, Wang GJ, Volkow ND, Fowler JS. Brain monoamine oxidase A activity predicts trait aggression. J Neurosci. 2008; 28:5099-5104. [PubMed: 18463263]

Amstislavskaya TG, Kudryavtseva NN. Effect of repeated experience of victory and defeat in daily agonistic confrontations on brain tryptophan hydroxylase activity. FEBS Lett. 1997; 406:106-108. [PubMed: 9109396] 
Anisman H, Du L, Palkovits M, Faludi G, Kovacs GG, Szontagh-Kishazi P, Merali Z, Poulter MO. Serotonin receptor subtype and p11 mRNA expression in stress-relevant brain regions of suicide and control subjects. J Psychiatry Neurosci. 2008; 33:131-141. [PubMed: 18330459]

Arango V, Underwood MD, Gubbi AV, Mann JJ. Localized alterations in pre- and postsynaptic serotonin binding sites in the ventrolateral prefrontal cortex of suicide victims. Brain Res. 1995; 688:121-133. [PubMed: 8542298]

Arias B, Collier DA, Gasto C, Pintor L, Gutierrez B, Valles V, Fananas L. Genetic variation in the 5HT5A receptor gene in patients with bipolar disorder and major depression. Neuroscience Lett. 2001; 303:111-114.

Assal F, Alarcon M, Solomon EC, Masterman D, Geschwind DH, Cummings JL. Association of the serotonin transporter and receptor gene polymorphisms in neuropsychiatric symptoms in Alzheimer disease. Arch Neurol. 2004; 61:1249-1253. [PubMed: 15313842]

Azenha D, Alves M, Matos R, Santa JF, Silva B, Cordeiro C, Vieira DN, Ambrósio AM. Male specific association between the 5-HTR6 gene 267C/T SNP and suicide in the Portuguese population. Neurosci Lett. 2009; 466:128-130. [PubMed: 19782122]

Azmitia EC, Gannon PJ, Kheck NM, Whitaker-Azmitia PM. Cellular localization of the 5-HT1A receptor in primate brain neurons and glial cells. Neuropsychopharmacology. 1996; 14:35-46. [PubMed: 8719028]

Aznar S, Qian Z, Shah R, Rahbek B, Knudsen GM. The 5-HT1A serotonin receptor is located on calbindin- and parvalbumin-containing neurons in the rat brain. Brain Res. 2003; 959:58-67. [PubMed: 12480158]

Baca-Garcia E, Diaz-Sastre C, Basurte E, Prieto R, Ceverino A, Saiz-Ruiz J, de Leon J. A prospective study of the paradoxical relationship between impulsivity and lethality of suicide attempts. J Clin Psychiatry. 2001; 62:560-564. [PubMed: 11488369]

Baca-Garcia E, Salgado BR, Segal HD, Lorenzo CV, Acosta MN, Romero MA, Hernandez MD, SaizRuiz J, Fernandez Piqueras J, de Leon J. A pilot genetic study of the continuum between compulsivity and impulsivity in females: the serotonin transporter promoter polymorphism. Prog Neuropsychopharmacol Biol Psychiatry. 2005; 29:713-717. [PubMed: 15908092]

Baca-Garcia E, Vaquero C, Diaz-Sastre C, Garcia-Resa E, Saiz-Ruiz J, Fernandez-Piqueras J, de Leon J. Lack of association between the serotonin transporter promoter gene polymorphism and impulsivity or aggressive behavior among suicide attempters and healthy volunteers. Psychiatry Res. 2004; 126:99-106. [PubMed: 15123389]

Bach-Mizrachi H, Underwood MD, Tin A, Ellis SP, Mann JJ, Arango V. Elevated expression of tryptophan hydroxylase-2 mRNA at the neuronal level in the dorsal and median raphe nuclei of depressed suicides. Mol Psychiatry. 2008; 13:507-513. [PubMed: 18180753]

Bach-Mizrachi H, Underwood MD, Kassir SA, Bakalian MJ, Sibille E, Tamir H, Mann JJ, Arango V. Neuronal tryptophan hydroxylase mRNA expression in the human dorsal and median raphe nuclei: Major depression and suicide. Neuropsychopharmacology. 2006; 31:814-824. [PubMed: 16192985]

Bah J, Lindstroem M, Westberg L, Manneras L, Ryding E, Henningsson S, Melke J, Rosen I, Traeskman-Bendz L, Eriksson E. Serotonin transporter gene polymorphisms: Effect on serotonin transporter availability in the brain of suicide attempters. Psychiat Res-Neuroim. 2008; 162:221229.

Baker KG, Halliday GM, Tork I. Cytoarchitecture of the human dorsal raphe nucleus. J Comp Neurol. 1990; 301:147-161. [PubMed: 2262589]

Balciuniene J, Emilsson L, Oreland L, Pettersson U, Jazin E. Investigation of the functional effect of monoamine oxidase polymorphisms in human brain. Hum Genet. 2002; 110:1-7. [PubMed: 11810289]

Bannai M, Fish EW, Faccidomo S, Miczek KA. Anti-aggressive effects of agonists at 5-HT1B receptors in the dorsal raphe nucleus of mice. Psychopharmacology. 2007; 193:295-304. [PubMed: 17440711]

Barkan T, Peled A, Modai I, Barak P, Weizman A, Rehavi M. Serotonin transporter characteristics in lymphocytes and platelets of male aggressive schizophrenia patients compared to non-aggressive schizophrenia patients. Eur Neuropsychopharmacol. 2006; 16:572-579. [PubMed: 16713194] 
Beaulieu JM, Zhang X, Rodriguiz RM, Sotnikova TD, Cools MJ, Wetsel WC, Gainetdinov RR, Caron MG. Role of GSK3 beta in behavioral abnormalities induced by serotonin deficiency. Proc Natl Acad Sci USA. 2008; 105:1333-1338. [PubMed: 18212115]

Beckett SR, Lawrence AJ, Marsden CA, Marshall PW. Attenuation of chemically induced defence response by 5-HT1 receptor agonists administered into the periaqueductal gray.

Psychopharmacology. 1992; 108:110-114. [PubMed: 1410130]

Beitchman JH, Baldassarra L, Mik H, De Luca V, King N, Bender D, Ehtesham S, Kennedy JL. Serotonin transporter polymorphisms and persistent, pervasive childhood aggression. Am J Psychiatry. 2006; 163:1103-1105. [PubMed: 16741214]

Bell R, Donaldson C, Gracey D. Differential effects of CGS 12066B and CP-94,253 on murine social and agonistic behaviour. Pharmacol Biochem Behav. 1995; 52:7-16. [PubMed: 7501681]

Bell R, Hobson H. 5-HT1A receptor influences on rodent social and agonistic behavior: a review and empirical study. Neurosci Biobehav Rev. 1994; 18:325-338. [PubMed: 7984351]

Bell R, Lynch K, Mitchell P. Lack of effect of the 5-HT(1A) receptor antagonist WAY-100635 on murine agonistic behaviour. Pharmacol Biochem Behav. 1999; 64:549-554. [PubMed: 10548270]

Bellivier F, Szoke A, Henry C, Lacoste J, Bottos C, Nosten-Bertrand M, Hardy P, Rouillon F, Launay JM, Laplanche JL, Leboyer M. Possible association between serotonin transporter gene polymorphism and violent suicidal behavior in mood disorders. Biol Psychiatry. 2000; 48:319322. [PubMed: 10960164]

Benko A, Lazary J, Molnar E, Gonda X, Tothfalusi L, Pap D, Mimics Z, Kurimay T, Chase D, Juhasz G, Anderson IM, Deakin JF, Bagdy G. Significant association between the C(-1019)G functional polymorphism of the HTR1A gene and impulsivity. Am J Med Genet B Neuropsychiatr Genet. 2010; 153:592-599. [PubMed: 19725031]

Berggard C, Damberg M, Longato-Stadler E, Hallman J, Oreland L, Garpenstrand H. The serotonin $2 \mathrm{~A}-1438 \mathrm{G} / \mathrm{A}$ receptor polymorphism in a group of Swedish male criminals. Neuroscience Lett. 2003; 347:196-198.

Blader JC. Pharmacotherapy and postdischarge outcomes of child inpatients admitted for aggressive behavior. J Clin Psychopharmacol. 2006; 26:419-425. [PubMed: 16855463]

Boldrini M, Underwood MD, Mann JJ, Arango V. More tryptophan hydroxylase in the brainstem dorsal raphe nucleus in depressed suicides. Brain Res. 2005; 1041:19-28. [PubMed: 15804496]

Bonaventure P, Hall H, Gommeren W, Cras P, Langlois X, Jurzak M, Leysen JE. Mapping of serotonin 5-HT(4) receptor mRNA and ligand binding sites in the post-mortem human brain. Synapse. 2000; 36:35-46. [PubMed: 10700024]

Bond AJ. Antidepressant treatments and human aggression. Eur J Pharmacol. 2005; 526:218-225. [PubMed: 16253231]

Bond PA, Cundall RL. Properties of Monoamine-Oxidase (Mao) in Human-Blood Platelets, Plasma, Lymphocytes and Granulocytes. Clin Chim Acta. 1977; 80:317-326. [PubMed: 912905]

Bondy B, Buettner A, Zill P. Genetics of suicide. Mol Psychiatry. 2006; 11:336-351. [PubMed: 16462816]

Bondy B, Erfurth A, de Jonge S, Kruger M, Meyer H. Possible association of the short allele of the serotonin transporter promoter gene polymorphism (5-HTTLPR) with violent suicide. Mol Psychiatry. 2000; 5:193-195. [PubMed: 10822348]

Bonkale WL, Turecki G, Austin MC. Increased tryptophan hydroxylase immunoreactivity in the dorsal raphe nucleus of alcohol-dependent, depressed suicide subjects is restricted to the dorsal subnucleus. Synapse. 2006; 60:81-85. [PubMed: 16596624]

Bonn M, Schmitt A, Lesch KP, Van Bockstaele EJ, Asan E. Serotonergic innervation and serotonin receptor expression of NPY-producing neurons in the rat lateral and basolateral amygdaloid nuclei. Brain Struct Funct. 2012 [Epub ahead of print].

Bortolato M, Godar SC, Alzghoul L, Zhang J, Darling RD, Simpson KL, Bini V, Chen K, Wellman CL, Lin RC, Shih JC. Monoamine oxidase A and A/B knockout mice display autistic-like features. Int J Neuropsychopharmacol. 2012a; 31:1-20.

Bortolato M, Godar SC, Melis M, Soggiu A, Roncada P, Casu A, Flore G, Chen K, Frau R, Urbani A, Castelli MP, Devoto P, Shih JC. NMDARs mediate the role of monoamine oxidase A in pathological aggression. J Neurosci. 2012b; 32:8574-8582. [PubMed: 22723698] 
Bortolato M, Shih JC. Behavioral outcomes of monoamine oxidase deficiency: preclinical and clinical evidence. Int Rev Neurobiol. 2011; 100:13-42. [PubMed: 21971001]

Bouwknecht JA, Hijzen TH, van der Gugten J, Maes RA, Hen R, Olivier B. Absence of 5-HT(1B) receptors is associated with impaired impulse control in male 5-HT(1B) knockout mice. Biol Psychiatry. 2001; 49:557-568. [PubMed: 11297712]

Bozina N, Jovanovic N, Podlesek A, Kuzman MR, Slijepcevic MK, Roguljic A, Dimitrovic A, Bozina T, Lovric J, Ljubic H, Medved V. Suicide ideators and attempters with schizophrenia - The role of 5-HTTLPR, rs25531, and 5-HTT VNTR Intron 2 variants. J Psychiatr Res. 2012; 46:767-773. [PubMed: 22520017]

Bray NJ, Buckland PR, Hall H, Owen MJ, O'Donovan MC. The serotonin-2A receptor gene locus does not contain common polymorphism affecting mRNA levels in adult brain. Mol Psychiatry. 2004; 9:109-114. [PubMed: 14699448]

Brown P, Molliver ME. Dual serotonin (5-HT) projections to the nucleus accumbens core and shell: relation of the 5-HT transporter to amphetamine-induced neurotoxicity. J Neurosci. 2000; 20:1952-1963. [PubMed: 10684896]

Brummett BH, Boyle SH, Siegler IC, Kuhn CM, Surwit RS, Garrett ME, Collins A, Ashley-Koch A, Williams RB. HPA axis function in male caregivers: effect of the monoamine oxidase-A gene promoter (MAOA-uVNTR). Biol Psychol. 2008; 79:250-255. [PubMed: 18639608]

Brunner HG, Nelen M, Breakefield XO, Ropers HH, van Oost BA. Abnormal behavior associated with a point mutation in the structural gene for monoamine oxidase A. Science. 1993a; 262:578-580. [PubMed: 8211186]

Brunner HG, Nelen MR, van Zandvoort P, Abeling NG, van Gennip AH, Wolters EC, Kuiper MA, Ropers HH, van Oost BA. X-linked borderline mental retardation with prominent behavioral disturbance: phenotype, genetic localization, and evidence for disturbed monoamine metabolism. Am J Hum Genet. 1993b; 52:1032-1039. [PubMed: 8503438]

Buckholtz JW, Meyer-Lindenberg A. MAOA and the neurogenetic architecture of human aggression. Trends Neurosci. 2008; 31:120-129. [PubMed: 18258310]

Burt SA, Mikolajewski AJ. Preliminary evidence that specific candidate genes are associated with adolescent-onset antisocial behavior. Aggress Behav. 2008; 34:437-445. [PubMed: 18366104]

Cadoret RJ, Langbehn D, Caspers K, Troughton EP, Yucuis R, Sandhu HK, Philibert R. Associations of the serotonin transporter promoter polymorphism with aggressivity, attention deficit, and conduct disorder in an adoptee population. Compr Psychiatry. 2003; 44:88-101. [PubMed: 12658617]

Campi-Azevedo AC, Boson W, De Marco L, Romano-Silva MA, Correa H. Association of the serotonin transporter promoter polymorphism with suicidal behavior. Mol Psychiatry. 2003; 8:899-900. [PubMed: 14593426]

Cao JX, Hu JA, Ye XM, Xia YA, Haile CA, Kosten TR, Zhang XY. Association between the 5HTR1B gene polymorphisms and alcohol dependence in a Han Chinese population. Brain Res. 2011; 1376:1-9. [PubMed: 21172311]

Caramaschi D, de Boer SF, Koolhaas JM. Differential role of the 5-HT1A receptor in aggressive and non-aggressive mice: an across-strain comparison. Physiol Behav. 2007; 90:590-601. [PubMed: 17229445]

Cargill M, Altshuler D, Ireland J, Sklar P, Ardlie K, Patil N, Lane CR, Lim EP, Kalyanaraman N, Nemesh J, Ziaugra L, Friedland L, Rolfe A, Warrington J, Lipshutz R, Daley GQ, Lander ES. Characterization of single-nucleotide polymorphisms in coding regions of human genes. Nat Genet. 1999; 22:231-238. [PubMed: 10391209]

Carkaci-Salli N, Salli U, Kuntz-Melcavage KL, Pennock MM, Ozgen H, Tekin I, Freeman WM, Vrana KE. TPH2 in the ventral tegmental area of the male rat brain. Brain res bulletin. 2011; 84:376380.

Carrillo M, Ricci LA, Coppersmith GA, Melloni RH Jr. The effect of increased serotonergic neurotransmission on aggression: a critical meta-analytical review of preclinical studies. Psychopharmacology. 2009; 205:349-368. [PubMed: 19404614] 
Cases O, Seif I, Grimsby J, Gaspar P, Chen K, Pournin S, Muller U, Aguet M, Babinet C, Shih JC, et al. Aggressive behavior and altered amounts of brain serotonin and norepinephrine in mice lacking MAOA. Science. 1995; 268:1763-1766. [PubMed: 7792602]

Caspi A, McClay J, Moffitt TE, Mill J, Martin J, Craig IW, Taylor A, Poulton R. Role of genotype in the cycle of violence in maltreated children. Science. 2002; 297:851-854. [PubMed: 12161658]

Caspi A, Sugden K, Moffitt TE, Taylor A, Craig IW, Harrington H, McClay J, Mill J, Martin J, Braithwaite A, Poulton R. Influence of life stress on depression: moderation by a polymorphism in the 5-HTT gene. Science. 2003; 301:386-389. [PubMed: 12869766]

Centenaro L, Vieira K, Zimmermann N, Miczek K, Lucion A, Almeida R. Social instigation and aggressive behavior in mice: role of 5-HT1A and 5-HT1B receptors in the prefrontal cortex. Psychopharmacology. 2008; 201:237-248. [PubMed: 18688602]

Cervantes MC, Biggs EA, Delville Y. Differential responses to serotonin receptor ligands in an impulsive-aggressive phenotype. Behav Neurosci. 2010; 124:455-469. [PubMed: 20695645]

Chen CK, Lin SK, Huang MC, Su LW, Hsiao CC, Chiang YL, Ree SC, Chiang SC, Liu HC. Analysis of association of clinical correlates and 5-HTTLPR polymorphism with suicidal behavior among Chinese methamphetamine abusers. Psychiat Clin Neuros. 2007; 61:479-486.

Chen GL, Vallender EJ, Miller GM. Functional characterization of the human TPH2 5 ' regulatory region: untranslated region and polymorphisms modulate gene expression in vitro. Hum Genet. 2008; 122:645-657. [PubMed: 17972101]

Chen K, Shih JC. Monoamine oxidase A and B: structure, function, and behavior. Adv Pharmacol. 1998; 42:292-296. [PubMed: 9327898]

Cirillo C, Vanden Berghe P, Tack J. Role of serotonin in gastrointestinal physiology and pathology. Minerva endocrinol. 2011; 36:311-324. [PubMed: 22322654]

Clark MS, Neumaier JF. The 5-HT1B receptor: behavioral implications. Psychopharmacology bull. 2001; 35:170-185.

Cleare AJ, Bond AJ. Ipsapirone challenge in aggressive men shows an inverse correlation between 5HT1A receptor function and aggression. Psychopharmacology. 2000; 148:344-349. [PubMed: 10928305]

Coccaro EF, Gabriel S, Siever LJ. Buspirone challenge: preliminary evidence for a role for central 5HT1a receptor function in impulsive aggressive behavior in humans. Psychopharmacology bull. 1990; 26:393-405.

Coccaro EF, Kavoussi RJ, Sheline Y1, Berman ME, Csernansky JG. Impulsive aggression in personality disorder correlates with platelet 5-HT2A receptor binding. Neuropsychopharmacology. 1997; 16:211-216. [PubMed: 9138437]

Coccaro EF, Lee R, Kavoussi RJ. Inverse relationship between numbers of 5-HT transporter binding sites and life history of aggression and intermittent explosive disorder. J Psychiatr Res. 2010; 44:137-142. [PubMed: 19767013]

Cohen IL, Liu X, Schutz C, White BN, Jenkins EC, Brown WT, Holden JJ. Association of autism severity with a monoamine oxidase A functional polymorphism. Clin Genet. 2003; 64:190-197. [PubMed: 12919132]

Compan V, Daszuta A, Salin P, Sebben M, Bockaert J, Dumuis A. Lesion study of the distribution of serotonin 5-HT4 receptors in rat basal ganglia and hippocampus. Eur J Neurosci. 1996; 8:25912598. [PubMed: 8996808]

Conner KR, Duberstein PR, Conwell Y, Caine ED. Reactive aggression and suicide: Theory and evidence. Aggress Violent Behav. 2003; 8:413-432.

Conner KR, Duberstein PR, Conwell Y, Seidlitz L, Caine ED. Psychological vulnerability to completed suicide: a review of empirical studies. Suicide Life Threat Behav. 2001; 31:367-385. [PubMed: 11775713]

Conner KR, Swogger MT, Houston RJ. A test of the reactive aggression-suicidal behavior hypothesis: is there a case for proactive aggression? J Abnorm Psychol. 2009; 118:235-240. [PubMed: 19222330]

Conner TS, Jensen KP, Tennen H, Furneaux HM, Kranzler HR, Covault J. Functional polymorphisms in the serotonin 1B receptor gene (HTR1B) predict self-reported anger and hostility among young men. Am J Med Genet B Neuropsychiatr Genet. 2010; 153:67-78. [PubMed: 19350534] 
Contini V, Marques FZ, Garcia CE, Hutz MH, Bau CH. MAOA-uVNTR polymorphism in a Brazilian sample: further support for the association with impulsive behaviors and alcohol dependence. Am J Med Genet B Neuropsychiatr Genet. 2006; 141:305-308. [PubMed: 16526025]

Conway CC, Keenan-Miller D, Hammen C, Lind PA, Najman JM, Brennan PA. Coaction of stress and serotonin transporter genotype in predicting aggression at the transition to adulthood. J Clin Child Adolesc Psychol. 2012; 41:53-63. [PubMed: 22233245]

Correa H, Campi-Azevedo AC, De Marco L, Boson W, Viana MM, Guimaraes MM, Costa E, Miranda DM, Romano-Silva MA. Familial suicide behaviour: association with probands suicide attempt characteristics and 5-HTTLPR polymorphism. Acta Psychiatr Scand. 2004; 110:459-464. [PubMed: 15521831]

Correa H, De Marco L, Boson W, Nicolato R, Teixeira AL, Campo VR, Romano-Silva MA. Association study of T102C 5-HT(2A) polymorphism in schizophrenic patients: diagnosis, psychopathology, and suicidal behavior. Dialogues Clin Neurosci. 2007; 9:97-101. [PubMed: 17506229]

Courtet P, Baud P, Abbar M, Boulenger JP, Castelnau D, Mouthon D, Malafosse A, Buresi C. Association between violent suicidal behavior and the low activity allele of the serotonin transporter gene. Mol Psychiatry. 2001; 6:338-341. [PubMed: 11326306]

Courtet P, Jollant F, Buresi C, Castelnau D, Mouthon D, Malafosse A. The monoamine oxidase A gene may influence the means used in suicide attempts. Psychiatr Genet. 2005; 15:189-193. [PubMed: 16094253]

Courtet P, Picot MC, Bellivier F, Torres S, Jollant F, Michelon C, Castelnau D, Astruc B, Buresi C, Malafosse A. Serotonin transporter gene may be involved in short-term risk of subsequent suicide attempts. Biol Psychiatry. 2004; 55:46-51. [PubMed: 14706424]

Coventry WL, James MR, Eaves LJ, Gordon SD, Gillespie NA, Ryan L, Heath AC, Montgomery GW, Martin NG, Wray NR. Do 5HTTLPR and Stress Interact in Risk for Depression and Suicidality? Item Response Analyses of a Large Sample. Am J Med Genet B. 2010; 153:757-765.

Crabbe JC, Phillips TJ, Feller DJ, Hen R, Wenger CD, Lessov CN, Schafer GL. Elevated alcohol consumption in null mutant mice lacking 5-HT1B serotonin receptors. Nat Genet. 1996; 14:98101. [PubMed: 8782828]

Crawford J, Sutherland GR, Goldney RD. No evidence for association of 5-HT2A receptor polymorphism with suicide. Am J Med Genet. 2000; 96:879-880. [PubMed: 11121203]

Czesak M, Lemonde S, Peterson EA, Rogaeva A, Albert PR. Cell-specific repressor or enhancer activities of Deaf-1 at a serotonin 1A receptor gene polymorphism. J Neurosci. 2006; 26:18641871. [PubMed: 16467535]

da Veiga CP, Miczek KA, Lucion AB, de Almeida RM. Social instigation and aggression in postpartum female rats: role of 5-Ht1A and 5-Ht1B receptors in the dorsal raphe nucleus and prefrontal cortex. Psychopharmacology. 2011; 213:475-487. [PubMed: 21107539]

Dahlstrom A, Fuxe K. Localization of monoamines in the lower brain stem. Experientia. 1964; 20:398-399. [PubMed: 5856530]

David SP, Murthy NV, Rabiner EA, Munafo MR, Johnstone EC, Jacob R, Walton RT, Grasby PM. A functional genetic variation of the serotonin (5-HT) transporter affects 5-HT1A receptor binding in humans. J Neurosci. 2005; 25:2586-2590. [PubMed: 15758168]

Davidson RJ, Putnam KM, Larson CL. Dysfunction in the neural circuitry of emotion regulation-a possible prelude to violence. Science. 2000; 289:591-594. [PubMed: 10915615]

Davies, MA.; Chang, CY.; Roth, BL. Polymorphic and posttranscriptional modifications of 5-HT receptor structure. In: Roth, BL., editor. The Serotonin Receptors. New Jersy: Humana Press; 2006. p. 59-90.

de Almeida RM, Giovenardi M, da Silva SP, de Oliveira VP, Stein DJ. Maternal aggression in Wistar rats: effect of 5-HT2A/2C receptor agonist and antagonist microinjected into the dorsal periaqueductal gray matter and medial septum. Braz J Med Biol Res. 2005; 38:597-602. [PubMed: 15962186]

De Almeida RM, Lucion AB. 8-OH-DPAT in the median raphe, dorsal periaqueductal gray and corticomedial amygdala nucleus decreases, but in the medial septal area it can increase maernal aggressive behavior in rats. Psychopharmacology. 1997; 134:392-400. [PubMed: 9452182] 
de Almeida RM, Nikulina EM, Faccidomo S, Fish EW, Miczek KA. Zolmitriptan-a 5-HT1B/D agonist, alcohol, and aggression in mice. Psychopharmacology. 2001; 157:131-141. [PubMed: 11594437]

De Almeida RM, Rosa MM, Santos DM, Saft DM, Benini Q, Miczek KA. 5-HT(1B) receptors, ventral orbitofrontal cortex, and aggressive behavior in mice. Psychopharmacology. 2006; 185:441-450. [PubMed: 16550387]

de Boer SF, Koolhaas JM. 5-HT1A and 5-HT1B receptor agonists and aggression: a pharmacological challenge of the serotonin deficiency hypothesis. Eur J Pharmacol. 2005; 526:125-139. [PubMed: 16310183]

De Luca V, Likhodi O, Kennedy JL, Wong AH. Differential expression and parent-of-origin effect of the 5-HT2A receptor gene C102T polymorphism: analysis of suicidality in schizophrenia and bipolar disorder. Am J Med Genet B Neuropsychiatr Genet. 2007; 144B:370-374. [PubMed: 17221840]

De Luca V, Strauss J, Kennedy JL. Power based association analysis (PBAT) of serotonergic and noradrenergic polymorphisms in bipolar patients with suicidal behaviour. Prog Neuropsychopharmacol Biol Psychiatry. 2008a; 32:197-203. [PubMed: 17869399]

De Luca V, Tharmaligam S, Strauss J, Kennedy JL. 5-ht2c receptor and mao-a interaction analysis: no association with suicidal behaviour in bipolar patients. Eur Arch Psy Clin N. 2008b; 258:428433.

De Luca V, Tharmalingam S, Muller DJ, Wong G, de Bartolomeis A, Kennedy JL. Gene-gene interaction between MAOA and COMT in suicidal behavior: Analysis in schizophrenia. Brain Res. 2006; 1097:26-30. [PubMed: 16725119]

De Luca V, Tharmalingam S, Sicard T, Kennedy JL. Gene-gene interaction between MAOA and COMT in suicidal behavior. Neuroscience Lett. 2005a; 383:151-154.

De Luca V, Voineskos D, Wong GWH, Shinkai T, Rothe C, Strauss J, Kennedy JL. Promoter polymorphism of second tryptophan hydroxylase isoform (TPH2) in schizophrenia and suicidality. Psychiatry Res. 2005b; 134:195-198. [PubMed: 15840421]

Deckert J, Catalano M, Syagailo YV, Bosi M, Okladnova O, Di Bella D, Nothen MM, Maffei P, Franke P, Fritze J, Maier W, Propping P, Beckmann H, Bellodi L, Lesch KP. Excess of high activity monoamine oxidase A gene promoter alleles in female patients with panic disorder. Hum Mol Genet. 1999; 8:621-624. [PubMed: 10072430]

Dekeyne A, Brocco M, Loiseau F, Gobert A, Rivet JM, Di Cara B, Cremers Tl, Flik G, Fone KC, Watson DJ, Papp M, Sharp T, Serres F, Cespuglio R, Olivier B, Chan JS, Lavielle G, Millan MJ. S32212, a novel serotonin type $2 \mathrm{C}$ receptor inverse agonist/alpha2-adrenoceptor antagonist and potential antidepressant: II. A behavioral, neurochemical, and electrophysiological characterization. J Pharmacol Exp Ther. 2012; 340:765-780. [PubMed: 22178753]

Delorme R, Durand CM, Betancur C, Wagner M, Ruhrmann S, Grabe HJ, Nygren G, Gillberg C, Leboyer M, Bourgeron T, Courtet P, Jollant F, Buresi C, Aubry JM, Baud P, Bondolfi G, Bertschy G, Perroud N, Malafosse A. No human tryptophan hydroxylase-2 gene R441H mutation in a large cohort of psychiatric patients and control subjects. Biol Psychiatry. 2006; 60:202-203. [PubMed: 16581035]

Delville Y, Mansour KM, Ferris CF. Serotonin blocks vasopressin-facilitated offensive aggression: interactions within the ventrolateral hypothalamus of golden hamsters. Physiol Behav. 1996; 59:813-816. [PubMed: 8778871]

Denney RM, Koch H, Craig IW. Association between monoamine oxidase A activity in human male skin fibroblasts and genotype of the MAOA promoter-associated variable number tandem repeat. Hum Genet. 1999; 105:542-551. [PubMed: 10647887]

Di Giovanni, G.; Di Matteo, V.; Esposito, E., editors. Serotonin-Dopamine Interaction: Experimental Evidence and Therapeutic Relevance. Amsterdam: Elsevier; 2008a. p. 1-665.

Di Giovanni G, Di Matteo V, Pierucci M, Esposito E. Serotonin-dopamine interaction: electrophysiological evidence. Prog Brain Res. 2008b; 172:45-71. [PubMed: 18772027]

Di Giovanni, G.; Esposito, E.; Di Matteo, V., editors. 5-HT2C Receptors in the Pathophysiology of CNS Disease. New York: Springer/Humana Press; 2011. p. 1-557. 
Di Matteo V, Pierucci M, Esposito E, Crescimanno G, Benigno A, Di Giovanni G. Serotonin modulation of the basal ganglia circuitry: therapeutic implication for Parkinson's disease and other motor disorders. Prog Brain Res. 2008; 172:423-463. [PubMed: 18772045]

Dougherty DM, Mathias CW, Marsh DM, Papageorgiou TD, Swann AC, Moeller FG. Laboratory measured behavioral impulsivity relates to suicide attempt history. Suicide Life Threat Behav. 2004; 34:374-385. [PubMed: 15585459]

Dracheva S, Chin B, Haroutunian V. Altered serotonin 2C receptor RNA splicing in suicide: association with editing. Neuroreport. 2008; 19:379-382. [PubMed: 18303585]

Drago A, Ronchi DD, Serretti A. 5-HT1A gene variants and psychiatric disorders: a review of current literature and selection of SNPs for future studies. Int J Neuropsychopharmacol. 2008; 11:701721. [PubMed: 18047755]

Du L, Bakish D, Lapierre YD, Ravindran AV, Hrdina PD. Association of polymorphism of serotonin $2 \mathrm{~A}$ receptor gene with suicidal ideation in major depressive disorder. Am J Med Genet. 2000; 96:56-60. [PubMed: 10686553]

Dubrovina, Nl; Popova, NK.; Gilinskii, MA.; Tomilenko, RA.; Seif, I. Acquisition and extinction of a conditioned passive avoidance reflex in mice with genetic knockout of monoamine oxidase A. Neurosci Behav Physiol. 2006; 36:335-339. [PubMed: 16583159]

Edwards AC, Dodge KA, Latendresse SJ, Lansford JE, Bates JE, Pettit GS, Budde JP, Goate AM, Dick DM. MAOA-uVNTR and early physical discipline interact to influence delinquent behavior. J Child Psychol Psychiatry. 2010; 51:679-687. [PubMed: 19951362]

Egashira T, Yamanaka Y. Further-Studies on the Synthesis of a-Form Monoamine-Oxidase. Jpn J Pharmacol. 1981; 31:763-770. [PubMed: 6273631]

Eisenberger, Nl; Way, BM.; Taylor, SE.; Welch, WT.; Lieberman, MD. Understanding genetic risk for aggression: clues from the brain's response to social exclusion. Biol Psychiatry. 2007; 61:11001108. [PubMed: 17137563]

Ertugrul A, Kennedy JL, Masellis M, Basile VS, Jayathilake K, Meltzer HY. No association of the T102C polymorphism of the serotonin $2 \mathrm{~A}$ receptor gene (HTR2A) with suicidality in schizophrenia. Schizophr Res. 2004; 69:301-305. [PubMed: 15469201]

Etain B, Rousseva A, Roy I, Henry C, Malafosse A, Buresi C, Preisig M, Rayah F, Leboyer M, Bellivier F. Lack of association between 5HT2A receptor gene haplotype, bipolar disorder and its clinical subtypes in a West European sample. Am J Med Genet B Neuropsychiatr Genet. 2004; 129:29-33. [PubMed: 15274035]

Evans J, Battersby S, Ogilvie AD, Smith CA, Harmar AJ, Nutt DJ, Goodwin GM. Association of short alleles of a VNTR of the serotonin transporter gene with anxiety symptoms in patients presenting after deliberate self harm. Neuropharmacology. 1997; 36:439-443. [PubMed: 9225267]

Faludi G, Du L, Palkovits M, Antal B, Sotonyi P, Hrdina PD. Serotonin transporter, serotonin-2A receptor and tryptophan hydroxilase gene polymorphisms in depressed suicide victims. Neurobiology. 2000; 8:269-271. [PubMed: 11225519]

Fanous AH, Chen X, Wang X, Amdur R, O'Neill FA, Walsh D, Kendler KS. Genetic variation in the serotonin $2 \mathrm{~A}$ receptor and suicidal ideation in a sample of 270 Irish high-density schizophrenia families. Am J Med Genet B Neuropsychiatr Genet. 2009; 150:411-417. [PubMed: 18712714]

Filippini N, Scassellati C, Boccardi M, Pievani M, Testa C, Bocchio-Chiavetto L, Frisoni GB, Gennarelli M. Influence of serotonin receptor 2A His452Tyr polymorphism on brain temporal structures: a volumetric MR study. Eur J Hum Genet. 2006; 14:443-449. [PubMed: 16434999]

Fish EW, Faccidomo S, Miczek KA. Aggression heightened by alcohol or social instigation in mice: reduction by the 5-HT(1B) receptor agonist CP-94,253. Psychopharmacology. 1999; 146:391399. [PubMed: 10550489]

Fiskerstrand CE, Lovejoy EA, Quinn JP. An intronic polymorphic domain often associated with susceptibility to affective disorders has allele dependent differential enhancer activity in embryonic stem cells. FEBS Lett. 1999; 458:171-174. [PubMed: 10481059]

Foley DL, Eaves LJ, Wormley B, Silberg JL, Maes HH, Kuhn J, Riley B. Childhood adversity, monoamine oxidase a genotype, and risk for conduct disorder. Arch Gen Psychiatry. 2004; 61:738-744. [PubMed: 15237086] 
Fowler JS, Alia-Klein N, Kriplani A, Logan J, Williams B, Zhu W, Craig IW, Telang F, Goldstein R, Volkow ND, Vaska P, Wang GJ. Evidence that brain MAO A activity does not correspond to MAO A genotype in healthy male subjects. Biol Psychiatry. 2007; 62:355-358. [PubMed: 17141746]

Frazzetto G, Di Lorenzo G, Carola V, Proietti L, Sokolowska E, Siracusano A, Gross C, Troisi A. Early trauma and increased risk for physical aggression during adulthood: the moderating role of MAOA genotype. PLoS One. 2007; 2:e486. [PubMed: 17534436]

Garriock HA, Allen JJ, Delgado P, Nahaz Z, Kling MA, Carpenter L, Burke M, Burke W, Schwartz T, Marangell LB, Husain M, Erickson RP, Moreno FA. Lack of association of TPH2 exon XI polymorphisms with major depression and treatment resistance. Mol Psychiatry. 2005; 10:976977. [PubMed: 16027738]

Gaysina D, Zainullina A, Gabdulhakov R, Khusnutdinova E. The serotonin transporter gene: Polymorphism and haplotype analysis in Russian suicide attempters. Neuropsychobiology. 2006; 54:70-74. [PubMed: 17028448]

Geddes JR, Freemantle N, Mason J, Eccles MP, Boynton J. SSRIs versus other antidepressants for depressive disorder. Cochrane Database Syst Rev. 2000; 2 CD001851.

Gérard C, Martres MP, Lefévre K, Miquel MC, Vergé D, Lanfumey L, Doucet E, Hamon M, el Mestikawy S. Immuno-localization of serotonin 5-HT6 receptor-like material in the rat central nervous system. Brain Res. 1997; 746:207-219. [PubMed: 9037500]

Gerra G, Garofano L, Castaldini L, Rovetto F, Zaimovic A, Moi G, Bussandri M, Branchi B, Brambilla F, Friso G, Donnini C. Serotonin transporter promoter polymorphism genotype is associated with temperament, personality traits and illegal drugs use among adolescents. J Neural Transm. 2005; 112:1397-1410. [PubMed: 15666036]

Gerra G, Garofano L, Santoro G, Bosari S, Pellegrini C, Zaimovic Z, Moi G, Bussandri M, Moi A, Brambilla F, Donnini C. Association between low-activity serotonin transporter genotype and heroin dependence: Behavioral and personality correlates. Am J Med Genet B. 2004; 126:37-42.

Gibb BE, McGeary JE, Beevers CG, Miller IW. Serotonin transporter (5-HTTLPR) genotype, childhood abuse, and suicide attempts in adult psychiatric inpatients. Suicide Life Threat Behav. 2006; 36:687-693. [PubMed: 17250473]

Giegling I, Hartmann AM, Moller HJ, Rujescu D. Anger- and aggression-related traits are associated with polymorphisms in the 5-HT-2A gene. J Affect Disord. 2006; 96:75-81. [PubMed: 16814396]

Godar SC, Bortolato M, Frau R, Dousti M, Chen K, Shih JC. Maladaptive defensive behaviours in monoamine oxidase A-deficient mice. Int J Neuropsychopharmacol. 2011; 14:1195-1207. [PubMed: 21156093]

Griebel G, Curet O, Perrault G, Sanger DJ. Behavioral effects of phenelzine in an experimental model for screening anxiolytic and anti-panic drugs: correlation with changes in monoamine-oxidase activity and monoamine levels. Neuropharmacology. 1998; 37:927-935. [PubMed: 9776388]

Grohmann M, Hammer P, Walther M, Paulmann N, Buttner A, Eisenmenger W, Baghai TC, Schule C, Rupprecht R, Bader M, Bondy B, Zill P, Priller J, Walther DJ. Alternative splicing and extensive RNA editing of human TPH2 transcripts. PLoS One. 2010; 5:e8956. [PubMed: 20126463]

Gureje O, Oladeji B, Hwang I, Chiu WT, Kessler RC, Sampson NA, Alonso J, Andrade LH, Beautrais A, Borges G, Bromet E, Bruffaerts R, de Girolamo G, de Graaf R, Gal G, He Y, Hu C, Iwata N, Karam EG, Kovess-Masfety V, Matschinger H, Moldovan MV, Posada-Villa J, Sagar R, Scocco P, Seedat S, Tomov T, Nock MK. Parental psychopathology and the risk of suicidal behavior in their offspring: results from the World Mental Health surveys. Mol Psychiatry. 2011; 16:12211233. [PubMed: 21079606]

Gurevich I, Tamir H, Arango V, Dwork AJ, Mann JJ, Schmauss C. Altered editing of serotonin 2C receptor pre-mRNA in the prefrontal cortex of depressed suicide victims. Neuron. 2002; 34:349356. [PubMed: 11988167]

Gustafson EL, Durkin MM, Bard JA, Zgombick J, Branchek TA. A receptor autoradiographic and in situ hybridization analysis of the distribution of the 5-ht7 receptor in rat brain. Br J Pharmacol. 1996; 117:657-666. [PubMed: 8646411] 
Haavik J, Blau N, Thony B. Mutations in human monoamine-related neurotransmitter pathway genes. Hum Mutat. 2008; 29:891-902. [PubMed: 18444257]

Haberstick BC, Smolen A, Hewitt JK. Family-based association test of the 5HTTLPR and aggressive behavior in a general population sample of children. Biol Psychiatry. 2006; 59:836-843. [PubMed: 16412987]

Hallikainen T, Saito T, Lachman HM, Volavka J, Pohjalainen T, Ryynanen OP, Kauhanen J, Syvalahti E, Hietala J, Tiihonen J. Association between low activity serotonin transporter promoter genotype and early onset alcoholism with habitual impulsive violent behavior. Mol Psychiatry. 1999; 4:385-388. [PubMed: 10483057]

Hamon M, Doucet E, Lefévre K, Miquel MC, Lanfumey L, Insausti R, Frechilla D, Del Rio J, Vergé D. Antibodies and antisense oligonucleotide for probing the distribution and putative functions of central 5-HT6 receptors. Neuropsychopharmacology. 1999; 21:68S-76S. [PubMed: 10432491]

Harvey ML, Swallows CL, Cooper MA. A double dissociation in the effects of 5-HT2A and 5-HT2C receptors on the acquisition and expression of conditioned defeat in Syrian hamsters. Behav Neurosci. 2012; 126:530-537. [PubMed: 22708954]

Hazelwood LA, Sanders-Bush E. His452Tyr polymorphism in the human 5-HT2A receptor destabilizes the signaling conformation. Mol Pharmacol. 2004; 66:1293-1300. [PubMed: 15496511]

Heils A, Teufel A, Petri S, Stober G, Riederer P, Bengel D, Lesch KP. Allelic variation of human serotonin transporter gene expression. J Neurochem. 1996; 66:2621-2624. [PubMed: 8632190]

Hennig J, Reuter M, Netter P, Burk C, Landt O. Two types of aggression are differentially related to serotonergic activity and the A779C TPH polymorphism. Behav Neurosci. 2005; 119:16-25. [PubMed: 15727508]

Higley JD, Linnoila M. Low central nervous system serotonergic activity is traitlike and correlates with impulsive behavior. A nonhuman primate model investigating genetic and environmental influences on neurotransmission. Ann N Y Acad Sci. 1997; 836:39-56. [PubMed: 9616793]

Hillegaart V. Functional topography of brain serotonergic pathways in the rat. Acta Physiol Scand. 1991; 598:1-54.

Ho HP, Olsson M, Westberg L, Melke J, Eriksson E. The serotonin reuptake inhibitor fluoxetine reduces sex steroid-related aggression in female rats: an animal model of premenstrual irritability? Neuropsychopharmacology. 2001; 24:502-510. [PubMed: 11282250]

Ho LW, Furlong RA, Rubinsztein JS, Walsh C, Paykel ES, Rubinsztein DC. Genetic associations with clinical characteristics in bipolar affective disorder and recurrent unipolar depressive disorder. Am J Med Genet. 2000; 96:36-42. [PubMed: 10686549]

Holmes A. Genetic variation in cortico-amygdala serotonin function and risk for stress-related disease. Neurosci Biobehav Rev. 2008; 32:1293-1314. [PubMed: 18439676]

Holmes A, Murphy DL, Crawley JN. Reduced aggression in mice lacking the serotonin transporter. Psychopharmacology. 2002; 161:160-167. [PubMed: 11981596]

Homberg JR, Pattij T, Janssen MC, Ronken E, De Boer SF, Schoffelmeer AN, Cuppen E. Serotonin transporter deficiency in rats improves inhibitory control but not behavioural flexibility. Eur J Neurosci. 2007; 26:2066-2073. [PubMed: 17897403]

Hong CJ, Pan GM, Tsai SJ. Association study of onset age, attempted suicide, aggressive behavior, and schizophrenia with a serotonin $1 \mathrm{~B}$ receptor $(\mathrm{A}-161 \mathrm{~T})$ genetic polymorphism.

Neuropsychobiology. 2004; 49:1-4. [PubMed: 14730192]

Hotamisligil GS, Breakefield XO. Human monoamine oxidase A gene determines levels of enzyme activity. Am J Hum Genet. 1991; 49:383-392. [PubMed: 1678250]

Hranilovic D, Stefulj J, Furac I, Kubat M, Balija M, Jernej B. Serotonin transporter gene promoter (5HTTLPR) and intron 2 (VNTR) polymorphisms in Croatian suicide victims. Biol Psychiatry. 2003; 54:884-889. [PubMed: 14573315]

Hu XZ, Lipsky RH, Zhu GS, Akhtar LA, Taubman J, Greenberg BD, Xu K, Arnold PD, Richter MA, Kennedy JL, Murphy DL, Goldman D. Serotonin transporter promoter gain-of-function genotypes are linked to obsessive-compulsive disorder. Am J Hum Genet. 2006; 78:815-826. [PubMed: 16642437] 
Huang YY, Battistuzzi C, Oquendo MA, Harkavy-Friedman J, Greenhill L, Zalsman G, Brodsky B, Arango V, Brent DA, Mann JJ. Human 5-HT1A receptor C(-1019)G polymorphism and psychopathology. Int J Neuropsychopharmacol. 2004a; 7:441-451. [PubMed: 15469667]

Huang YY, Cate SP, Battistuzzi C, Oquendo MA, Brent D, Mann JJ. An association between a functional polymorphism in the monoamine oxidase a gene promoter, impulsive traits and early abuse experiences. Neuropsychopharmacology. 2004b; 29:1498-1505. [PubMed: 15150530]

Huang YY, Grailhe R, Arango V, Hen R, Mann JJ. Relationship of psychopathology to the human serotonin1B genotype and receptor binding kinetics in postmortem brain tissue. Neuropsychopharmacology. 1999; 21:238-246. [PubMed: 10432472]

Huang YY, Oquendo MA, Friedman JM, Greenhill LL, Brodsky B, Malone KM, Khait V, Mann JJ. Substance abuse disorder and major depression are associated with the human 5-HT1B receptor gene (HTR1B) G861C polymorphism. Neuropsychopharmacology. 2003; 28:163-169. [PubMed: 12496953]

Hull-Blanks EE, Kerr BA, Robinson Kurpius SE. Risk factors of suicidal ideations and attempts in talented, at-risk girls. Suicide Life Threat Behav. 2004; 34:267-276. [PubMed: 15385181]

Hung CF, Lung FW, Hung TH, Chong MY, Wu CK, Wen JK, Lin PY. Monoamine oxidase A gene polymorphism and suicide: An association study and meta-analysis. J Affect Disord. 2012; 136:643-649. [PubMed: 22041522]

Imbrici P, Tucker SJ, D'Adamo MC, Pessia M. Role of receptor protein tyrosine phosphatase alpha (RPTPalpha) and tyrosine phosphorylation in the serotonergic inhibition of voltage-dependent potassium channels. Pflugers Arch. 2000; 441:257-262. [PubMed: 11211111]

Isel F, Ciesielski L, Gobaille S, Molina V, Mandel P. Alterations of serotonin neurotransmission and inhibition of mouse killing behavior: II. Effects of selective and reversible monoamine oxidase inhibitors of type A. Pharmacol Biochem Behav. 1988; 29:97-104. [PubMed: 2832858]

Jacobs BL, Azmitia EC. Structure and function of the brain serotonin system. Physiol Rev. 1992; 72:165-229. [PubMed: 1731370]

Jahng JW, Houpt TA, Wessel TC, Chen K, Shih JC, Joh TH. Localization of monoamine oxidase A and B mRNA in the rat brain by in situ hybridization. Synapse. 1997; 25:30-36. [PubMed: 8987145]

Jansen F, Heiming RS, Kloke V, Kaiser S, Palme R, Lesch KP, Sachser N. Away game or home match: the influence of venue and serotonin transporter genotype on the display of offensive aggression. Behav Brain Res. 2011; 219:291-301. [PubMed: 21262270]

Jensen KP, Covault J, Conner TS, Tennen H, Kranzler HR, Fumeaux HM. A common polymorphism in serotonin receptor 1B mRNA moderates regulation by miR-96 and associates with aggressive human behaviors. Mol Psychiatry. 2009; 14:381-389. [PubMed: 18283276]

Jernej B, Stefulj J, Hranilovic D, Balija M, Skavic J, Kubat M. Intronic polymorphism of tryptophan hydroxylase and serotonin transporter: indication for combined effect in predisposition to suicide. J Neural Transm. 2004; 111:733-738. [PubMed: 15168220]

Kantor S, Anheuer ZE, Bagdy G. High social anxiety and low aggression in Fawn-Hooded rats. Physiol Behav. 2000; 71:551-557. [PubMed: 11239674]

Ke L, Qi ZY, Ping Y, Ren CY. Effect of SNP at position 40237 in exon 7 of the TPH2 gene on susceptibility to suicide. Brain Res. 2006; 1122:24-26. [PubMed: 17011525]

Kerman IA, Clinton SM, Bedrosian TA, Abraham AD, Rosenthal DT, Akil H, Watson SJ. High novelty-seeking predicts aggression and gene expression differences within defined serotonergic cell groups. Brain Res. 2011; 1419:34-45. [PubMed: 21925645]

Khait VD, Huang YY, Zalsman G, Oquendo MA, Brent DA, Harkavy-Friedman JM, Mann JJ. Association of serotonin 5-HT2A receptor binding and the T102C polymorphism in depressed and healthy Caucasian subjects. Neuropsychopharmacology. 2005; 30:166-172. [PubMed: 15483560]

Kim-Cohen J, Caspi A, Taylor A, Williams B, Newcombe R, Craig IW, Moffitt TE. MAOA, maltreatment, and gene-environment interaction predicting children's mental health: new evidence and a meta-analysis. Mol Psychiatry. 2006; 11:903-913. [PubMed: 16801953]

Kim JJ, Shih JC, Chen K, Chen L, Bao S, Maren S, Anagnostaras SG, Fanselow MS, De Maeyer E, Seif I, Thompson RF. Selective enhancement of emotional, but not motor, learning in 
monoamine oxidase A-deficient mice. Proc Natl Acad Sci USA. 1997; 94:5929-5933. [PubMed: 9159177]

Kim YR, Jahng JW, Min SK. Association between the serotonin transporter gene (5-HTTLPR) and anger-related traits in Korean schizophrenic patients. Neuropsychobiology. 2009; 59:165-171. [PubMed: 19439997]

Koh KB, Kim CH, Choi EH, Lee YJ, Seo WY. Effect of tryptophan hydroxylase gene polymorphism on aggression in major depressive disorder and undifferentiated somatoform disorder. J Clin Psychiatry. 2012; 73:e574-e579. [PubMed: 22697203]

Koller G, Bondy B, Preuss UW, Bottlender M, Soyka M. No association between a polymorphism in the promoter region of the MAOA gene with antisocial personality traits in alcoholics. Alcohol and alcoholism. 2003; 38:31-34. [PubMed: 12554604]

Korte SM, Meijer OC, de Kloet ER, Buwalda B, Keijser J, Sluyter F, van Oortmerssen G, Bohus B. Enhanced 5-HT1A receptor expression in forebrain regions of aggressive house mice. Brain Res. 1996; 736:338-343. [PubMed: 8930340]

Kouzmenko AP, Scaffidi A, Pereira AM, Hayes WL, Copolov DL, Dean B. No correlation between A(-1438)G polymorphism in 5-HT2A receptor gene promoter and the density of frontal cortical 5-HT2A receptors in schizophrenia. Hum Hered. 1999; 49:103-105. [PubMed: 10077731]

Kraft JB, Slager SL, McGrath PJ, Hamilton SP. Sequence analysis of the serotonin transporter and associations with antidepressant response. Biol Psychiatry. 2005; 58:374-381. [PubMed: 15993855]

Kulikov AV, Osipova DV, Naumenko VS, Popova NK. Association between Tph2 gene polymorphism, brain tryptophan hydroxylase activity and aggressiveness in mouse strains. Genes, brain, and behavior. 2005; 4:482-485.

Kunugi H, Ishida S, Kato T, Tatsumi M, Sakai T, Hattori M, Hirose T, Nanko S. A functional polymorphism in the promoter region of monoamine oxidase-A gene and mood disorders. Mol Psychiatry. 1999; 4:393-395. [PubMed: 10483059]

Lambe EK, Fillman SG, Webster MJ, Shannon Weickert C. Serotonin receptor expression in human prefrontal cortex: balancing excitation and inhibition across postnatal development. PLoS One. 2011; 6:e22799. [PubMed: 21829518]

Lappalainen J, Dean M, Charbonneau L, Virkkunen M, Linnoila M, Goldman D. Mapping of the Serotonin 5-Ht1d-Beta Autoreceptor Gene on Chromosome-6 and Direct Analysis for Sequence Variants. Am J Med Genet. 1995; 60:157-161. [PubMed: 7485252]

Lauterbach E, Brunner J, Hawellek B, Lewitzka U, Ising M, Bondy B, Rao ML, Frahnert C, Rujescu D, Muller-Oerlinghausen B, Schley J, Heuser I, Maier W, Hohagen F, Felber W, Bronisch T. Platelet 5-HT2A receptor binding and tryptophan availability in depression are not associated with recent history of suicide attempts but with personality traits characteristic for suicidal behavior. J Affect Disord. 2006; 91:57-62. [PubMed: 16412522]

Leathwood PD, Fernstrom JD. Effect of an oral tryptophan/carbohydrate load on tryptophan, large neutral amino acid, and serotonin and 5-hydroxyindoleacetic acid levels in monkey brain. $\mathrm{J}$ Neural Transm. 1990; 79:25-34.

Lemonde S, Turecki G, Bakish D, Du LS, Hrdina PD, Bown CD, Sequeira A, Kushwaha N, Morris SJ, Basak A, Ou XM, Albert PR. Impaired repression at a 5-hydroxytryptamine 1A receptor gene polymorphism associated with major depression and suicide. J Neurosci. 2003; 23:8788-8799. [PubMed: 14507979]

Lesch KP, Bengel D, Heils A, Sabol SZ, Greenberg BD, Petri S, Benjamin J, Muller CR, Hamer DH, Murphy DL. Association of anxiety-related traits with a polymorphism in the serotonin transporter gene regulatory region. Science. 1996; 274:1527-1531. [PubMed: 8929413]

Lesch KP, Gutknecht L. Pharmacogenetics of the serotonin transporter. Prog Neuropsychopharmacol Biol Psychiatry. 2005; 29:1062-1073. [PubMed: 15951088]

Lesch KP, Merschdorf U. Impulsivity, aggression, and serotonin: a molecular psychobiological perspective. Behav Sci Law. 2000; 18:581-604. [PubMed: 11113963]

Lesch KP, Wolozin BL, Estler HC, Murphy DL, Riederer P. Isolation of a cDNA encoding the human brain serotonin transporter. J Neural Transm. 1993a; 91:67-72. 
Lesch KP, Wolozin BL, Murphy DL, Reiderer P. Primary structure of the human platelet serotonin uptake site: identity with the brain serotonin transporter. J Neurochem. 1993b; 60:2319-2322. [PubMed: 7684072]

Li D, He L. Meta-analysis supports association between serotonin transporter (5-HTT) and suicidal behavior. Mol Psychiatry. 2007; 12:47-54. [PubMed: 16969368]

Lim JE, Pinsonneault J, Sadee W, Saffen D. Tryptophan hydroxylase 2 (TPH2) haplotypes predict levels of TPH2 mRNA expression in human pons. Mol Psychiatry. 2007; 12:491-501. [PubMed: 17453063]

Limosin F, Loze JY, Boni C, Hamon M, Ades J, Rouillon F, Gorwood P. Male-specific association between the 5-HTTLPRS allele and suicide attempts in alcohol-dependent subjects. J Psychiatr Res. 2005; 39:179-182. [PubMed: 15589566]

Liu S, Bubar MJ, Lanfranco MF, Hillman GR, Cunningham KA. Serotonin2C receptor localization in GABA neurons of the rat medial prefrontal cortex: implications for understanding the neurobiology of addiction. Neuroscience. 2007; 146:1677-1688. [PubMed: 17467185]

Llado-Pelfort L, Santana N, Ghisi V, Artigas F, Celada P. 5-HT1A receptor agonists enhance pyramidal cell firing in prefrontal cortex through a preferential action on GABA interneurons. Cereb Cortex. 2012; 22:1487-1497. [PubMed: 21893679]

Lopez-Mendoza D, Aguilar-Bravo H, Swanson HH. Combined effects of Gepirone and (+)WAY 100135 on territorial aggression in mice. Pharmacol Biochem Behav. 1998; 61:1-8. [PubMed: 9715801]

Lopez de Lara C, Brezo J, Rouleau G, Lesage A, Dumont M, Alda M, Benkelfat C, Turecki G. Effect of tryptophan hydroxylase-2 gene variants on suicide risk in major depression. Biol Psychiatry. 2007; 62:72-80. [PubMed: 17217922]

Lopez VA, Detera-Wadleigh S, Cardona I, Kassem L, McMahon FJ. Nested association between genetic variation in tryptophan hydroxylase II, bipolar affective disorder, and suicide attempts. Biol Psychiatry. 2007; 61:181-186. [PubMed: 16806105]

Lothe A, Boni C, Costes N, Bouvard S, Gorwood P, Lavenne F, Alvarez M, Ryvlin P. 5-HT1A gene promoter polymorphism and [F-18]MPPF binding potential in healthy subjects: a PET study. HYPERLINK "http://www.ncbi.nlm.nih.gov/pubmed/"lo "Behavioral and brain functions : BBF.". Behav Brain Funct. 2010; 6:37. [PubMed: 20609217]

Lowther S, DePaermentier F, Cheetham SC, Crompton MR, Katona CLE, Horton RW. 5-HT1A receptor binding sites in post-mortem brain samples from depressed suicides and controls. J Affect Disord. 1997; 42:199-207. [PubMed: 9105961]

Lung FW, Tzeng DS, Huang MF, Lee MB. Association of the MAOA promoter uVNTR polymorphism with suicide attempts in patients with major depressive disorder. BMC Med Genet. 2011; 12:74. [PubMed: 21605465]

Luque JM, Kwan SW, Abell CW, DaPrada M, Richards JG. Cellular expression of mRNAs encoding monoamine oxidases A and B in the rat central nervous system. J Comp Neurol. 1995; 363:665680. [PubMed: 8847423]

MacKenzie A, Quinn J. A serotonin transporter gene intron 2 polymorphic region, correlated with affective disorders, has allele-dependent differential enhancer-like properties in the mouse embryo. P Natl Acad Sci USA. 1999; 96:15251-15255.

Malloy-Diniz LF, Neves FS, de Moraes PHP, De Marco LA, Romano-Silva MA, Krebs MO, Correa H. The 5-HTTLPR polymorphism, impulsivity and suicide behavior in euthymic bipolar patients. J Affect Disord. 2011; 133(1-2):221-226. [PubMed: 21550122]

Mann JJ. Role of the serotonergic system in the pathogenesis of major depression and suicidal behavior. Neuropsychopharmacology. 1999; 21:S99-S105.

Mann JJ, Arango VA, Avenevoli S, Brent DA, Champagne FA, Clayton P, Currier D, Dougherty DM, Haghighi F, Hodge SE, Kleinman J, Lehner T, McMahon F, Moscicki EK, Oquendo MA, Pandey GN, Pearson J, Stanley B, Terwilliger J, Wenzel A. Candidate endophenotypes for genetic studies of suicidal behavior. Biol Psychiatry. 2009; 65:556-563. [PubMed: 19201395]

Mann JJ, Arango V, Henteleff RA, Lagattuta TF, Wong DT. Serotonin 5-HT3 receptor binding kinetics in the cortex of suicide victims are normal. J Neural Transm. 1996; 103:165-171. [PubMed: 9026370] 
Mann JJ, Brent DA, Arango V. The neurobiology and genetics of suicide and attempted suicide: a focus on the serotonergic system. Neuropsychopharmacology. 2001; 24:467-477. [PubMed: 11282247]

Mann JJ, Huang JY, Underwood MD, Kassir SA, Oppenheim S, Kelly TM, Dwork AJ, Arango V. A serotonin transporter gene promoter polymorphism (5-HTTLPR) and prefrontal cortical finding in major depression and suicide. Arch Gen Psychiatry. 2000; 57:729-738. [PubMed: 10920459]

Mann JJ, McBride PA, Anderson GM, Mieczkowski TA. Platelet and whole blood serotonin content in depressed inpatients: correlations with acute and life-time psychopathology. Biol Psychiatry. 1992; 32:243-257. [PubMed: 1420642]

Manuck SB, Flory JD, Ferrell RE, Dent KM, Mann JJ, Muldoon MF. Aggression and anger-related traits associated with a polymorphism of the tryptophan hydroxylase gene. Biol Psychiatry. 1999; 45:603-614. [PubMed: 10088047]

Marazziti D, Baroni S, Pirone A, Giannaccini G, Betti L, Testa G, Schmid L, Palego L, Borsini F, Bordi F, Piano I, Gargini C, Castagna M, Catena-Dell'osso M, Lucacchini A. Serotonin receptor of type 6 (5-HT6) in human prefrontal cortex and hippocampus postmortem: An immunohistochemical and immunofluorescence study. Neurochem Int. in press

Mathews TA, Fedele DE, Coppelli FM, Avila AM, Murphy DL, Andrews AM. Gene dose-dependent alterations in extraneuronal serotonin but not dopamine in mice with reduced serotonin transporter expression. Journal of neuroscience methods. 2004; 140:169-181. [PubMed: 15589347]

May ME, Lightfoot DA, Srour A, Kowalchuk RK, Kennedy CH. Association between serotonin transporter polymorphisms and problem behavior in adult males with intellectual disabilities. Brain Res. 2010; 1357:97-103. [PubMed: 20735998]

Mayser W, Betz H, Schloss P. Isolation of cDNAs encoding a novel member of the neurotransmitter transporter gene family. FEBS Lett. 1991; 295:203-206. [PubMed: 1765155]

McDermott R, Tingley D, Cowden J, Frazzetto G, Johnson DD. Monoamine oxidase A gene (MAOA) predicts behavioral aggression following provocation. Proc Natl Acad Sci USA. 2009; 106:21182123. [PubMed: 19168625]

McDonald AJ, Mascagni F. Neuronal localization of 5-HT type 2A receptor immunoreactivity in the rat basolateral amygdala. Neuroscience. 2007; 146:306-320. [PubMed: 17331657]

McKenzie-Quirk SD, Girasa KA, Allan AM, Miczek KA. 5-HT(3) receptors, alcohol and aggressive behavior in mice. Behav Pharmacol. 2005; 16:163-169. [PubMed: 15864071]

Mejia JM, Ervin FR, Baker GB, Palmour RM. Monoamine oxidase inhibition during brain development induces pathological aggressive behavior in mice. Biol Psychiatry. 2002; 52:811821. [PubMed: 12372653]

Mendlewicz J, Massat I, Souery D, Del-Favero J, Oruc L, Nothen MM, Blackwood D, Muir W, Battersby S, Lerer B, Segman RH, Kaneva R, Serretti A, Lilli R, Lorenzi C, Jakovljevic M, Ivezic S, Rietschel M, Milanova V, Van Broeckhoven C. Serotonin transporter 5HTTLPR polymorphism and affective disorders: no evidence of association in a large European multicenter study. Eur J Hum Genet. 2004; 12:377-382. [PubMed: 14735161]

Meyer-Lindenberg A, Buckholtz JW, Kolachana B, A RH, Pezawas L, Blasi G, Wabnitz A, Honea R, Verchinski B, Callicott JH, Egan M, Mattay V, Weinberger DR. Neural mechanisms of genetic risk for impulsivity and violence in humans. Proc Natl Acad Sci USA. 2006; 103:6269-6274. [PubMed: 16569698]

Meyer JH, Wilson AA, Rusjan P, Clark M, Houle S, Woodside S, Arrowood J, Martin K, Colleton M. Serotonin2A receptor binding potential in people with aggressive and violent behaviour. $\mathrm{J}$ Psychiatry Neurosci. 2008; 33:499-508. [PubMed: 18982172]

Miczek KA, Mos J, Olivier B. Brain 5-HT and inhibition of aggressive behavior in animals: 5-HIAA and receptor subtypes. Psychopharmacology bulletin. 1989; 25:399-403. [PubMed: 2483273]

Milatovich A, Hsieh CL, Bonaminio G, Tecott L, Julius D, Francke U. Serotonin receptor 1c gene assigned to X chromosome in human (band q24) and mouse (bands D-F4). Hum Mol Genet. 1992; 1:681-684. [PubMed: 1302605] 
Miquel MC, Emerit MB, Nosjean A, Simon A, Rumajogee P, Brisorgueil MJ, Doucet E, Hamon M, Verge D. Differential subcellular localization of the 5-HT3-As receptor subunit in the rat central nervous system. Eur J Neurosci. 2002; 15:449-457. [PubMed: 11876772]

Mitchell PJ. Antidepressant treatment and rodent aggressive behaviour. Eur J Pharmacol. 2005; 526:147-162. [PubMed: 16289453]

Mitchell PJ, Fletcher A, Redfern PH. Is antidepressant efficacy revealed by drug-induced changes in rat behaviour exhibited during social interaction? Neurosci Biobehav Rev. 1991; 15:539-544. [PubMed: 1792016]

Mitchell PJ, Redfern PH. Acute and chronic antidepressant drug treatments induce opposite effects in the social behaviour of rats. J Psychopharmacol. 1992; 6:241-257. [PubMed: 22291357]

Morales M, Bloom FE. The 5-HT3 receptor is present in different subpopulations of GABAergic neurons in the rat telencephalon. J Neurosci. 1997; 17:3157-3167. [PubMed: 9096150]

Morikawa H, Manzoni OJ, Crabbe JC, Williams JT. Regulation of central synaptic transmission by 5HT(1B) auto- and heteroreceptors. Mol Pharmacol. 2000; 58(6):1271-1278. [PubMed: 11093763]

Mos J, Olivier B, Poth M, van Aken H. The effects of intraventricular administration of eltoprazine, 1(3-trifluoromethylphenyl)piperazine hydrochloride and 8-hydroxy-2-(di-n-propylamino)tetralin on resident intruder aggression in the rat. Eur J Pharmacol. 1992; 212:295-298. [PubMed: 1534769]

Mos J, Olivier B, Poth M, Van Oorschot R, Van Aken H. The effects of dorsal raphe administration of eltoprazine, TFMPP and 8-OH-DPAT on resident intruder aggression in the rat. Eur J Pharmacol. 1993; 238:411-415. [PubMed: 8405111]

Mosienko V, Bert B, Beis D, Matthes S, Fink H, Bader M, Alenina N. Exaggerated aggression and decreased anxiety in mice deficient in brain serotonin. HYPERLINK "http:// www.ncbi.nlm.nih.gov/" \o "Translational psychiatry.". Transl Psychiatry. 2012; 29(2):e122. [PubMed: 22832966]

Mouri K, Hishimoto A, Fukutake M, Shiroiwa K, Asano M, Nagasaki Y, Ueno Y, Shirakawa O, Nishiguchi N, Maeda K. TPH2 is not a susceptibility gene for suicide in Japanese population. Prog Neuropsychopharmacol Biol Psychiatry. 2009; 33:1546-1550. [PubMed: 19748542]

Muehlenkamp F, Lucion A, Vogel WH. Effects of selective serotonergic agonists on aggressive behavior in rats. Pharmacol Biochem Behav. 1995; 50:671-674. [PubMed: 7617717]

Muehlenkamp JJ, Gutierrez PM. An investigation of differences between self-injurious behavior and suicide attempts in a sample of adolescents. Suicide \& life-threatening behavior. 2004; 34:12-23. [PubMed: 15106884]

Muramatsu M, Lapiz MD, Tanaka E, Grenhoff J. Serotonin inhibits synaptic glutamate currents in rat nucleus accumbens neurons via presynaptic 5-HT1B receptors. Eur J Neurosci. 1998; 10:23712379. [PubMed: 9749765]

Murphy DL, Fox MA, Timpano KR, Moya PR, Ren-Patterson R, Andrews AM, Holmes A, Lesch KP, Wendland JR. How the serotonin story is being rewritten by new gene-based discoveries principally related to SLC6A4, the serotonin transporter gene, which functions to influence all cellular serotonin systems. Neuropharmacology. 2008a; 55:932-960. [PubMed: 18824000]

Murphy KL, Zhang X, Gainetdinov RR, Beaulieu JM, Caron MG. A regulatory domain in the N terminus of tryptophan hydroxylase 2 controls enzyme expression. The Journal of biological chemistry. 2008b; 283:13216-13224. [PubMed: 18339632]

Murphy TM, Ryan M, Foster T, Kelly C, McClelland R, O'Grady J, Corcoran E, Brady J, Reilly M, Jeffers A, Brown K, Maher A, Bannan N, Casement A, Lynch D, Bolger S, Tewari P, Buckley A, Quinlivan L, Daly L, Kelleher C, Malone KM. Risk and protective genetic variants in suicidal behaviour: association with SLC1A2, SLC1A3, 5-HTR1B \&NTRK2 polymorphisms. Behav Brain Funct. 2011; 7:22. [PubMed: 21711518]

Must A, Tasa G, Lang A, Vasar E, Koks S, Maron E, Vali M. Variation in tryptophan hydroxylase-2 gene is not associated to male completed suicide in Estonian population. Neuroscience Lett. 2009; 453:112-114. 
Myers RL, Airey DC, Manier DH, Shelton RC, Sanders-Bush E. Polymorphisms in the regulatory region of the human serotonin 5-HT2A receptor gene (HTR2A) influence gene expression. Biol Psychiatry. 2007; 61:167-173. [PubMed: 16697352]

Navarro JF, Ibanez M, Luna G. Behavioral profile of SB 269970, a selective 5-HT(7) receptor antagonist, in social encounters between male mice. Methods Find Exp Clin Pharmacol. 2004; 7:515-518. [PubMed: 15538540]

Neves FS, Malloy-Diniz LF, Romano-Silva MA, Aguiar GC, de Matos LO, Correa H. Is the serotonin transporter polymorphism (5-HTTLPR) a potential marker for suicidal behavior in bipolar disorder patients? J Affect Disord. 2010; 125:98-102. [PubMed: 20096463]

Neves FS, Silveira G, Romano-Silva MA, Malloy-Diniz L, Ferreira AA, De Marco L, Correa H. Is the 5-HTTLPR Polymorphism Associated With Bipolar Disorder or With Suicidal Behavior of Bipolar Disorder Patients? Am J Med Genet B. 2008; 147:114-116.

New AS, Buchsbaum MS, Hazlett EA, Goodman M, Koenigsberg HW, Lo J, Iskander L, Newmark R, Brand J, O'Flynn K, Siever LJ. Fluoxetine increases relative metabolic rate in prefrontal cortex in impulsive aggression. Psychopharmacology. 2004; 176:451-458. [PubMed: 15160265]

New AS, Gelernter J, Goodman M, Mitropoulou V, Koenigsberg H, Silverman J, Siever LJ. Suicide, impulsive aggression, and HTR1B genotype. Biol Psychiatry. 2001; 50:62-65. [PubMed: 11457425]

New AS, Gelernter J, Yovell Y, Trestman RL, Nielsen DA, Silverman J, Mitropoulou V, Siever LJ. Tryptophan hydroxylase genotype is associated with impulsive-aggression measures: a preliminary study. Am J Med Genet. 1998; 81:13-17. [PubMed: 9514581]

Nishiguchi N, Shirakawa O, Ono H, Nishimura A, Nushida H, Ueno Y, Maeda K. No evidence of an association between 5HT1B receptor gene polymorphism and suicide victims in a Japanese population. Am J Med Genet. 2001; 105:343-345. [PubMed: 11378847]

Nishiguchi N, Shirakawa O, Ono H, Nishimura A, Nushida H, Ueno Y, Maeda K. Lack of an association between 5-HT1A receptor gene structural polymorphisms and suicide victims. Am J Med Genet. 2002; 114:423-425. [PubMed: 11992564]

Nock MK, Borges G, Bromet EJ, Cha CB, Kessler RC, Lee S. Suicide and Suicidal Behavior. Epidemiol Rev. 2008; 30:133-154. [PubMed: 18653727]

Nolan KA, Volavka J, Lachman HM, Saito T. An association between a polymorphism of the tryptophan hydroxylase gene and aggression in schizophrenia and schizoaffective disorder. Psychiatr Genet. 2000; 10:109-115. [PubMed: 11204346]

Nomura M, Nomura Y. Psychological, neuroimaging, and biochemical studies on functional association between impulsive behavior and the 5-HT2A receptor gene polymorphism in humans. Ann N Y Acad Sci. 2006; 1086:134-143. [PubMed: 17185512]

Noskova T, Pivac N, Nedic G, Kazantseva A, Gaysina D, Faskhutdinova G, Gareeva A, Khahlova Z, Khusnutdinova E, Kovacic DK, Kovacic Z, Jokic H, Seler DM. Ethnic differences in the serotonin transporter polymorphism (5-HTTLPR) in several European populations. Prog Neuropsychopharmacol Biol Psychiatry. 2008; 32:1735-1739. [PubMed: 18700161]

Nothen MM, Erdmann J, Shimronabarbanell D, Propping P. Identification of Genetic-Variation in the Human Serotonin 1d-Beta Receptor Gene. Biochem Bioph Res Co. 1994; 205:1194-1200.

Ohara K, Xie DW, Ishigaki T, Deng ZL, Nakamura Y, Suzuki Y, Miyasato K, Ohara K. The genes encoding the 5HT(1D alpha) and 5HT(1D beta) receptors are unchanged in patients with panic disorder. Biol Psychiatry. 1996; 39:5-10. [PubMed: 8719119]

Ohtani M, Shindo S, Yoshioka N. Polymorphisms of the tryptophan hydroxylase gene and serotonin 1A receptor gene in suicide victims among Japanese. Tohoku J Exp Med. 2004; 202:123-133. [PubMed: 14998306]

Okamura K, Shirakawa O, Nishiguchi N, Ono H, Nushida H, Ueno Y, Maeda K. Lack of an association between 5-HT receptor gene polymorphisms and suicide victims. Psychiatry Clin Neurosci. 2005; 59:345-349. [PubMed: 15896229]

Olivier B. Serotonin and aggression. Ann N Y Acad Sci. 2004; 1036:382-392. [PubMed: 15817750]

Olivier B, Mos J, van der Heyden J, Hartog J. Serotonergic modulation of social interactions in isolated male mice. Psychopharmacology. 1989; 97:154-156. [PubMed: 2498921] 
Olivier B, Mos J, van Oorschot R, Hen R. Serotonin receptors and animal models of aggressive behavior. Pharmacopsychiatry. 1995; 28(Suppl 2):80-90. [PubMed: 8614705]

Ono H, Shirakawa O, Nishiguchi N, Nishimura A, Nushida H, Ueno Y, Maeda K. Serotonin 2A receptor gene polymorphism is not associated with completed suicide. J Psychiatr Res. 2001; 35:173-176. [PubMed: 11461713]

Ono H, Shirakawa O, Nishiguchi N, Nishimura A, Nushida H, Ueno Y, Maeda K. No evidence of an association between a functional monoamine oxidase A gene polymorphism and completed suicides. Am J Med Genet. 2002; 114:340-342. [PubMed: 11920860]

Oquendo MA, Russo SA, Underwood MD, Kassir SA, Ellis SP, Mann JJ, Arango V. Higher postmortem prefrontal 5-HT2A receptor binding correlates with lifetime aggression in suicide. Biol Psychiatry. 2006; 59:235-243. [PubMed: 16140277]

Oreland L, Nilsson K, Damberg M, Hallman J. Monoamine oxidases: activities, genotypes and the shaping of behaviour. J Neural Transm. 2007; 114:817-822. [PubMed: 17426915]

Osipova DV, Kulikov AV, Popova NK. C1473G polymorphism in mouse tph2 gene is linked to tryptophan hydroxylase- 2 activity in the brain, intermale aggression, and depressive-like behavior in the forced swim test. J Neurosci Res. 2009; 87:1168-1174. [PubMed: 19006079]

Oswald P, Souery D, Massat I, Del-Favero J, Linotte S, Papadimitriou G, Dikeos D, Kaneva R, Milanova V, Oruc L, Ivezic S, Serretti A, Lilli R, Van Broeckhoven C, Mendlewicz J. Lack of association between the 5HT2A receptor polymorphism (T102C) and unipolar affective disorder in a multicentric European study. Eur Neuropsychopharmacol. 2003; 13:365-368. [PubMed: 12957335]

Ozaki N, Manji H, Lubierman V, Lu SJ, Lappalainen J, Rosenthal NE, Goldman D. A naturally occurring amino acid substitution of the human serotonin 5-HT2A receptor influences amplitude and timing of intracellular calcium mobilization. J Neurochem. 1997; 68:2186-2193. [PubMed: 9109547]

Parsey RV, Oquendo MA, Simpson NR, Ogden RT, Van Heertum R, Arango V, Mann JJ. Effects of sex, age, and aggressive traits in man on brain serotonin 5-HT1A receptor binding potential measured by PET using [C-11]WAY-100635. Brain res. 2002; 954:173-182. [PubMed: 12414100]

Pasqualetti M, Ori M, Castagna M, Marazziti D, Cassano GB, Nardi I. Distribution and cellular localization of the serotonin type $2 \mathrm{C}$ receptor messenger RNA in human brain. Neuroscience. 1999; 92:601-611. [PubMed: 10408609]

Patkar AA, Berrettini WH, Hoehe M, Thornton CC, Gottheil E, Hill K, Weinstein SP. Serotonin transporter polymorphisms and measures of impulsivity, aggression, and sensation seeking among African-American cocaine-dependent individuals. Psychiatry Res. 2002; 110:103-115. [PubMed: 12057823]

Perez-Rodriguez MM, Weinstein S, New AS, Bevilacqua L, Yuan Q, Zhou Z, Hodgkinson C, Goodman M, Koenigsberg HW, Goldman D, Siever LJ. Tryptophan-hydroxylase 2 haplotype association with borderline personality disorder and aggression in a sample of patients with personality disorders and healthy controls. J Psychiatr Res. 2010; 44:1075-1081. [PubMed: 20451217]

Perroud N, Neidhart E, Petit B, Vessaz M, Laforge T, Relecom C, La Harpe R, Malafosse A, Guipponi M. Simultaneous Analysis of Serotonin Transporter, Tryptophan Hydroxylase 1 and 2 Gene Expression in the Ventral Prefrontal Cortex of Suicide Victims. Am J Med Genet B. 2010; 153:909-918.

Pfeffer CR, Jiang H, Kakuma T. Child-Adolescent Suicidal Potential Index (CASPI): a screen for risk for early onset suicidal behavior. Psychol Assess. 2000; 12:304-318. [PubMed: 11021154]

Pinna G, Dong E, Matsumoto K, Costa E, Guidotti A. In socially isolated mice, the reversal of brain allopregnanolone down-regulation mediates the anti-aggressive action of fluoxetine. Proc Natl Acad Sci USA. 2003; 100:2035-2040. [PubMed: 12571361]

Pivac, N.; Nikolac, M.; Nedic, G.; Mück-Seler, D. Genetics of suicidal behaviour. In: Wiederhold, BK., editor. Coping with posttraumatic stress disorder in returning troops. Wounds of war II. NATO Science through peace and security series E: human and societal dynamics. Amsterdam: Washington, D.C.: IOS Press Amsterdam; 2010. p. 31-55. 
Plutchik R. Outward and inward directed aggressiveness: the interaction between violence and suicidality. Pharmacopsychiatry. 1995; 28(Suppl 2):47-57. [PubMed: 8614701]

Polesskaya OO, Sokolov BP. Differential expression of the "C" and "T" alleles of the 5-HT2A receptor gene in the temporal cortex of normal individuals and schizophrenics. J Neurosci Res. 2002; 67:812-822. [PubMed: 11891796]

Poncelet M, Perio A, Simiand J, Gout G, Soubrie P, Le Fur G. Antidepressant-like effects of SR 57227A, a 5-HT3 receptor agonist, in rodents. J Neural Transm Gen Sect. 1995; 102:83-90. [PubMed: 8748673]

Pooley EC, Houston K, Hawton K, Harrison PJ. Deliberate self-harm is associated with allelic variation in the tryptophan hydroxylase gene (TPH A779C), but not with polymorphisms in five other serotonergic genes. Psychol Med. 2003; 33:775-783. [PubMed: 12877392]

Popova NK, Naumenko VS, Plyusnina IZ. Involvement of brain serotonin 5-HT1A receptors in genetic predisposition to aggressive behavior. Neurosci Behav Physiol. 2007; 37:631-635. [PubMed: 17657435]

Popova NK, Naumenko VS, Plyusnina IZ, Kulikov AV. Reduction in 5-HT1A receptor density, 5HT1A mRNA expression, and functional correlates for 5-HT1A receptors in genetically defined aggressive rats. J Neurosci Res. 2005; 80:286-292. [PubMed: 15765530]

Popova NK, Skrinskaya YA, Amstislavskaya TG, Vishnivetskaya GB, Seif I, de Meier E. Behavioral characteristics of mice with genetic knockout of monoamine oxidase type A. Neurosci Behav Physiol. 2001; 31:597-602. [PubMed: 11766896]

Popova NK, Voitenko NN, Kulikov AV, Avgustinovich DF. Evidence for the involvement of central serotonin in mechanism of domestication of silver foxes. Pharmacol Biochem Behav. 1991; 40:751-756. [PubMed: 1816562]

Poulin F, Boivin M. Reactive and proactive aggression: evidence of a two-factor model. Psychol Assess. 2000; 12:115-122. [PubMed: 10887757]

Preuss UW, Koller G, Bahlmann M, Soyka M, Bondy B. No association between suicidal behavior and 5-HT2A-T102C polymorphism in alcohol dependents. Am J Med Genet. 2000; 96:877-878. [PubMed: 11121202]

Pruus K, Skrebuhhova-Malmros T, Rudissaar R, Matto V, Allikmets L. 5-HT1A receptor agonists buspirone and gepirone attenuate apomorphine-induced aggressive behaviour in adult male Wistar rats. J Physiol Pharmacol. 2000; 51:833-846. [PubMed: 11220492]

Puig MV, Santana N, Celada P, Mengod G, Artigas F. In vivo excitation of GABA interneurons in the medial prefrontal cortex through 5-HT3 receptors. Cereb Cortex. 2004; 14:1365-1375. [PubMed: 15166106]

Pungercic G, Videtic A, Pestotnik A, Pajnic IZ, Zupanc T, Balazic J, Tomori M, Komel R. Serotonin transporter gene promoter (5-HTTLPR) and intron 2 (VNTR) polymorphisms: a study on Slovenian population of suicide victims. Psychiatr Genet. 2006; 16:187-191. [PubMed: 16969272]

Reist C, Nakamura K, Sagart E, Sokolski KN, Fujimoto KA. Impulsive aggressive behavior: openlabel treatment with citalopram. J Clin Psychiatry. 2003; 64:81-85. [PubMed: 12590628]

Reynolds GP, Mason SL, Meldrum A, De Keczer S, Parnes H, Eglen RM, Wong EH. 5Hydroxytryptamine (5-HT) 4 receptors in post mortem human brain tissue: distribution, pharmacology and effects of neurodegenerative diseases. Br J Pharmacol. 1995; 114:993-998. [PubMed: 7780656]

Ricci LA, Grimed JM, Melloni RH Jr. Serotonin type 3 receptors modulate the aggression-stimulating effect of adolescent cocaine exposure in Syrian hamsters (Mesocricetus auratus). Behav Neurosci. 2004; 118:1097-1110. [PubMed: 15506892]

Ricci LA, Knyshevski I, Melloni RH Jr. Serotonin type 3 receptors stimulate offensive aggression in Syrian hamsters. Behav Brain Res. 2005; 156:19-29. [PubMed: 15474647]

Risinger FO, Doan AM, Vickrey AC. Oral operant ethanol self-administration in 5-HT1b knockout mice. Behav Brain Res. 1999; 102:211-215. [PubMed: 10403028]

Robinson ES, Dalley JW, Theobald DE, Glennon JC, Pezze MA, Murphy ER, Robbins TW. Opposing roles for 5-HT2A and 5-HT2C receptors in the nucleus accumbens on inhibitory response control 
in the 5-choice serial reaction time task. Neuropsychopharmacology. 2008; 33:2398-2406. [PubMed: 18046307]

Rosel P, Arranz B, Urretavizcaya M, Oros M, San L, Navarro MA. Altered 5-HT2A and 5-HT4 postsynaptic receptors and their intracellular signalling systems IP3 and cAMP in brains from depressed violent suicide victims. Neuropsychobiology. 2004; 49:189-195. [PubMed: 15118356]

Rosell DR, Thompson JL, Slifstein M, Xu X, Frankle WG, New AS, Goodman M, Weinstein SR, Laruelle M, Abi-Dargham A, Siever LJ. Increased serotonin 2A receptor availability in the orbitofrontal cortex of physically aggressive personality disordered patients. Biol Psychiatry. 2010; 67:1154-1162. [PubMed: 20434136]

Rosenzweig-Lipson S, Sabb A, Stack G, Mitchell P, Lucki I, Malberg JE, Grauer S, Brennan J, Cryan JF, Sukoff Rizzo SJ, Dunlop J, Barrett JE, Marquis KL. Antidepressant-like effects of the novel, selective, 5-HT2C receptor agonist WAY-163909 in rodents. Psychopharmacology. 2007; 192:159-170. [PubMed: 17297636]

Roy A, Hu XZ, Janal MN, Goldman D. Interaction between childhood trauma and serotonin transporter gene variation in suicide. Neuropsychopharmacology. 2007; 32:2046-2052. [PubMed: 17356577]

Rudissaar R, Pruus K, Skrebuhhova T, Allikmets L, Matto V. Modulatory role of 5-HT3 receptors in mediation of apomorphine-induced aggressive behaviour in male rats. Behav Brain Res. 1999; 106:91-96. [PubMed: 10595424]

Rujescu D, Giegling I, Bondy B, Gietl A, Zill P, Moller HJ. Association of anger-related traits with SNPs in the TPH gene. Mol Psychiatry. 2002; 7:1023-1029. [PubMed: 12399958]

Rujescu D, Giegling I, Sato T, Moller HJ. Lack of association between serotonin 5-HT1B receptor gene polymorphism and suicidal behavior. Am J Med Genet B Neuropsychiatr Genet. 2003; 116:69-71. [PubMed: 12497617]

Rylands AJ, Hinz R, Jones M, Holmes SE, Feldmann M, Brown G, McMahon AW, Talbot PS. Preand Postsynaptic Serotonergic Differences in Males with Extreme Levels of Impulsive Aggression Without Callous Unemotional Traits: A Positron Emission Tomography Study Using (11)C-DASB and (11)C-MDL100907. Biol Psychiatry. 2012 [Epub ahead of print].

Sabol SZ, Hu S, Hamer D. A functional polymorphism in the monoamine oxidase A gene promoter. Hum Genet. 1998; 103:273-279. [PubMed: 9799080]

Saiz PA, Garcia-Portilla MP, Paredes B, Arango C, Morales B, Alvarez V, Coto E, Bascaran MT, Bousono M, Bobes J. Association between the A-1438G polymorphism of the serotonin 2A receptor gene and nonimpulsive suicide attempts. Psychiatr Genet. 2008; 18:213-218. [PubMed: 18797395]

Sakai JT, Young SE, Stallings MC, Timberlake D, Smolen A, Stetler GL, Crowley TJ. Case-control and within-family tests for an association between conduct disorder and 5HTTLPR. Am J Med Genet B Neuropsychiatr Genet. 2006; 141:825-832. [PubMed: 16972235]

Sakaue M, Ago Y, Sowa C, Sakamoto Y, Nishihara B, Koyama Y, Baba A, Matsuda T. Modulation by 5-hT2A receptors of aggressive behavior in isolated mice. HYPERLINK "http:// www.ncbi.nlm.nih.gov/" \o "Japanese journal of pharmacology.". Jpn J Pharmacol. 2002; 89:89_ 92. [PubMed: 12083749]

Samochowiec J, Lesch KP, Rottmann M, Smolka M, Syagailo YV, Okladnova O, Rommelspacher H, Winterer G, Schmidt LG, Sander T. Association of a regulatory polymorphism in the promoter region of the monoamine oxidase A gene with antisocial alcoholism. Psychiatry Res. 1999; 86:67-72. [PubMed: 10359483]

Sanchez C, Arnt J, Hyttel J, Moltzen EK. The role of serotonergic mechanisms in inhibition of isolation-induced aggression in male mice. Psychopharmacology. 1993; 110:53-59. [PubMed: 7870899]

Sanchez C, Hyttel J. Isolation-induced aggression in mice: effects of 5-hydroxytryptamine uptake inhibitors and involvement of postsynaptic 5-HT1A receptors. Eur J Pharmacol. 1994; 264:241247. [PubMed: 7698161]

Sanders AR, Cao Q, Taylor J, Levin TE, Badner JA, Cravchik A, Comeron JM, Naruya S, Del Rosario A, Salvi DA, Walczyk KA, Mowry BJ, Levinson DF, Crowe RR, Silverman JM, Gejman PV. 
Genetic diversity of the human serotonin receptor 1B (HTR1B) gene. Genomics. 2001; 72:1-14. [PubMed: 11247661]

Santana N, Bortolozzi A, Serrats J, Mengod G, Artigas F. Expression of serotonin1A and serotonin2A receptors in pyramidal and GABAergic neurons of the rat prefrontal cortex. Cereb Cortex. 2004; 14:1100-1109. [PubMed: 15115744]

Saudou F, Amara DA, Dierich A, LeMeur M, Ramboz S, Segu L, Buhot MC, Hen R. Enhanced aggressive behavior in mice lacking 5-HT1B receptor. Science. 1994; 265:1875-1878. [PubMed: 8091214]

Saura J, Richards JG, Mahy N. Age-Related-Changes on Mao in BI/C57 Mouse-Tissues - a Quantitative Autoradiographic Study. J Neural Transm-Supp. 1994; 41:89-94.

Scherer LJ, McPherson JD, Wasmuth JJ, Marsh JL. Human dopa decarboxylase: localization to human chromosome 7p11 and characterization of hepatic cDNAs. Genomics. 1992; 13:469-471. [PubMed: 1612608]

Scott AL, Bortolato M, Chen K, Shih JC. Novel monoamine oxidase A knock out mice with humanlike spontaneous mutation. Neuroreport. 2008; 19:739-743. [PubMed: 18418249]

Serretti A, Calati R, Giegling I, Hartmann AM, Moller HJ, Rujescu D. Serotonin receptor HTR1A and HTR2C variants and personality traits in suicide attempters and controls. J Psychiatr Res. 2009; 43:519-525. [PubMed: 18715570]

Serretti A, Drago A, De Ronchi D. HTR2A gene variants and psychiatric disorders: a review of current literature and selection of SNPs for future studies. Curr Med Chem. 2007; 14:2053-2069. [PubMed: 17691947]

Shen YF, Li HF, Gu NF, Tan Z, Tang JX, Fan JB, Li XW, Sun W, He L. Relationship between suicidal behavior of psychotic inpatients and serotonin transporter gene in Han Chinese. Neuroscience lett. 2004; 372:94-98.

Sijbesma H, Schipper J, de Kloet ER. Eltoprazine, a drug which reduces aggressive behaviour, binds selectively to 5-HT1 receptor sites in the rat brain: an autoradiographic study. Eur J Pharmacol. 1990; 177:55-66. [PubMed: 2340856]

Silva H, Iturra P, Solari A, Villarroel J, Jerez S, Jimenez M, Galleguillos F, Bustamante ML. Fluoxetine response in impulsive-aggressive behavior and serotonin transporter polymorphism in personality disorder. Psychiatr Genet. 2010; 20:25-30. [PubMed: 20010449]

Skrebuhhova-Malmros T, Pruus K, Rudissaar R, Allikmets L, Matto V. The serotonin 5-HT(2A) receptor subtype does not mediate apomorphine-induced aggressive behaviour in male Wistar rats. Pharmacol Biochem Behav. 2000; 67:339-343. [PubMed: 11124399]

Smith AR, Witte TK, Teale NE, King SL, Bender TW, Joiner TE. Revisiting impulsivity in suicide: implications for civil liability of third parties. Behav Sci Law. 2008; 26:779-797. [PubMed: 19039790]

Smith HR, Porrino LJ. The comparative distributions of the monoamine transporters in the rodent, monkey, and human amygdala. Brain Struct Funct. 2008; 213:73-91. [PubMed: 18283492]

Soloff PH, Price JC, Mason NS, Becker C, Meltzer CC. Gender, personality, and serotonin-2A receptor binding in healthy subjects. Psychiatry Res. 2010; 181:77-84. [PubMed: 19959344]

Souza RP, De Luca V, Manchia M, Kennedy JL. Are serotonin 3A and 3B receptor genes associated with suicidal behavior in schizophrenia subjects? Neurosci Lett. 2011; 489:137-141. [PubMed: 21184810]

Soyka M, Preuss UW, Koller G, Zill P, Bondy B. Association of 5-HT1B receptor gene and antisocial behavior in alcoholism. J Neural Transm. 2004; 111:101-109. [PubMed: 14714219]

Sparkes RS, Lan N, Klisak I, Mohandas T, Diep A, Kojis T, Heinzmann C, Shih JC. Assignment of a serotonin 5HT-2 receptor gene (HTR2) to human chromosome 13q14-q21 and mouse chromosome 14. Genomics. 1991; 9:461-465. [PubMed: 2032718]

Spurlock G, Heils A, Holmans P, Williams J, D'Souza UM, Cardno A, Murphy KC, Jones L, Buckland PR, McGuffin P, Lesch KP, Owen MJ. A family based association study of T102C polymorphism in 5HT2A and schizophrenia plus identification of new polymorphisms in the promoter. Mol Psychiatry. 1998; 3:42-49. [PubMed: 9491812]

Staner L, Uyanik G, Correa H, Tremeau F, Monreal J, Crocq MA, Stefos G, Morris-Rosendahl DJ, Macher JP. A dimensional impulsive-aggressive phenotype is associated with the A218C 
polymorphism of the tryptophan hydroxylase gene: a pilot study in well-characterized impulsive inpatients. Am J Med Genet. 2002; 114:553-557. [PubMed: 12116193]

Stanley B, Molcho A, Stanley M, Winchel R, Gameroff MJ, Parsons B, Mann JJ. Association of aggressive behavior with altered serotonergic function in patients who are not suicidal. Am $\mathbf{J}$ Psychiatry. 2000; 157:609-614. [PubMed: 10739421]

Steckler T, Rammes G, Sauvage M, van Gaalen MM, Weis C, Zieglgansberger W, Holsboer F. Effects of the monoamine oxidase A inhibitor moclobemide on hippocampal plasticity in GR-impaired transgenic mice. J Psychiatr Res. 2001; 35:29-42. [PubMed: 11287054]

Stefulj J, Buttner A, Skavic J, Zill P, Balija M, Eisenmenger W, Bondy B, Jernej B. Serotonin 1B (5HT-1B) receptor polymorphism (G861C) in suicide victims: association studies in German and Slavic population. Am J Med Genet B Neuropsychiatr Genet. 2004; 127:48-50. [PubMed: 15108179]

Stefulj J, Mokrovic G, Hranilovic D, Bordukalo-Niksic T, Bakula M, Kubat M, Jernej B. Functional promoter polymorphism of the neuronal isoform of tryptophan hydroxylase (Tph2) in suicide. Psychiatry Res. 2011; 186:446-447. [PubMed: 20869124]

Stockmeier CA, Shapiro LA, Dilley GE, Kolli TN, Friedman L, Rajkowska G. Increase in serotonin-1A autoreceptors in the midbrain of suicide victims with major depression-postmortem evidence for decreased serotonin activity. J Neurosci. 1998; 18:7394-7401. [PubMed: 9736659]

Sukonick DL, Pollock BG, Sweet RA, Mulsant BH, Rosen J, Klunk WE, Kastango KB, DeKosky ST, Ferrell RE. The 5-HTTPR*S/*L polymorphism and aggressive behavior in Alzheimer disease. Arch Neurol. 2001; 58:1425-1428. [PubMed: 11559314]

Suzuki H, Han SD, Lucas LR. Increased 5-HT1B receptor density in the basolateral amygdala of passive observer rats exposed to aggression. Brain Res Bull. 2010; 83:38-43. [PubMed: 20599596]

Sweet RA, Pollock BG, Sukonick DL, Mulsant BH, Rosen J, Klunk WE, Kastango KB, DeKosky ST, Ferrell RE. The 5-HTTPR polymorphism confers liability to a combined phenotype of psychotic and aggressive behavior in Alzheimer disease. Int Psychogeriatr. 2001; 13:401-409. [PubMed: 12003247]

Szewczyk B, Albert PR, Burns AM, Czesak M, Overholser JC, Jurjus GJ, Meltzer HY, Konick LC, Dieter L, Herbst N, May W, Rajkowska G, Stockmeier CA, Austin MC. Gender-specific decrease in NUDR and 5-HT1A receptor proteins in the prefrontal cortex of subjects with major depressive disorder. Int J Neuropsychopharmacol. 2009; 12:155-168. [PubMed: 18561871]

Tan EC, Chong SA, Chan AO, Tan CH. No evidence for association of the T102C polymorphism in the serotonin type 2A receptor with suicidal behavior in schizophrenia. Am J Med Genet. 2002; 114:321-322. [PubMed: 11920856]

Tanaka E, North RA. Actions of 5-hydroxytryptamine on neurons of the rat cingulate cortex. J Neurophysiol. 1993; 69:1749-1757. [PubMed: 8389838]

Tecott LH, Maricq AV, Julius D. Nervous system distribution of the serotonin 5-HT3 receptor mRNA. Proc Natl Acad Sci USA. 1993; 90:1430-1434. [PubMed: 8434003]

Thompson JH. Serotonin and the alimentary tract. Res Commun Mol Pathol Pharmacol. 1971; 2:687781.

To ZP, Bonhaus DW, Eglen RM, Jakeman LB. Characterization and distribution of putative 5-ht7 receptors in guinea-pig brain. Br J Pharmacol. 1995; 115:107-116. [PubMed: 7647964]

Torrente MP, Gelenberg AJ, Vrana KE. Boosting serotonin in the brain: is it time to revamp the treatment of depression? J Psychopharmacol. 2012; 26:629-635. [PubMed: 22158544]

Troisi A, Vicario E, Nuccetelli F, Ciani N, Pasini A. Effects of fluoxetine on aggressive behavior of adult inpatients with mental retardation and epilepsy. Pharmacopsychiatry. 1995; 28:73-76. [PubMed: 7568367]

Tsai SJ, Chiu HJ, Wang YC, Hong CJ. Association study of serotonin-6 receptor variant (C267T) with schizophrenia and aggressive behavior. Neurosci Lett. 1999; 271:135-137. [PubMed: 10477121]

Tsai SJ, Hong CJ, Yu YW, Chen TJ, Wang YC, Lin WK. Association study of serotonin 1B receptor (A-161T) genetic polymorphism and suicidal behaviors and response to fluoxetine in major depressive disorder. Neuropsychobiology. 2004; 50:235-238. [PubMed: 15365222] 
Turecki G. Suicidal behavior: is there a genetic predisposition? Bipolar Disord. 2001; 3:335-349. [PubMed: 11843783]

Turecki G. Dissecting the suicide phenotype: the role of impulsive-aggressive behaviours. J Psychiatry Neurosci. 2005; 30:398-408. [PubMed: 16327873]

Turecki G, Briere R, Dewar K, Antonetti T, Lesage AD, Seguin M, Chawky N, Vanier C, Alda M, Joober R, Benkelfat C, Rouleau GA. Prediction of level of serotonin 2A receptor binding by serotonin receptor $2 \mathrm{~A}$ genetic variation in postmortem brain samples from subjects who did or did not commit suicide. Am J Psychiat. 1999; 156:1456-1458. [PubMed: 10484964]

Turecki G, Sequeira A, Gingras Y, Seguin M, Lesage A, Tousignant M, Chawky N, Vanier C, Lipp O, Benkelfat C, Rouleau GA. Suicide and serotonin: study of variation at seven serotonin receptor genes in suicide completers. Am J Med Genet B Neuropsychiatr Genet. 2003; 118:36-40. [PubMed: 12627464]

Underwood MD, Khaibulina AA, Ellis SP, Moran A, Rice PM, Mann JJ, Arango V. Morphometry of the dorsal raphe nucleus serotonergic neurons in suicide victims. Biol Psychiatry. 1999; 46:473483. [PubMed: 10459396]

Van Bockstaele EJ, Biswas A, Pickel VM. Topography of serotonin neurons in the dorsal raphe nucleus that send axon collaterals to the rat prefrontal cortex and nucleus accumbens. Brain Res. 1993; 624:188-198. [PubMed: 8252391]

Van Bockstaele EJ, Pickel VM. Ultrastructure of serotonin-immunoreactive terminals in the core and shell of the rat nucleus accumbens: cellular substrates for interactions with catecholamine afferents. J Comp Neurol. 1993; 334:603-617. [PubMed: 8408768]

Vaquero-Lorenzo C, Baca-Garcia E, Diaz-Hernandez M, Perez-Rodriguez MM, Fernandez-Navarro P, Giner L, Carballo JJ, Saiz-Ruiz J, Fernandez-Piqueras J, Baldomero EB, de Leon J, Oquendo MA. Association study of two polymorphisms of the serotonin-2A receptor gene and suicide attempts. Am J Med Genet B. 2008; 147:645-649.

Vaquero-Lorenzo C, Riaza Bermudo-Soriano C, Perez-Rodriguez MM, Diaz-Hernandez M, LopezCastroman J, Fernandez-Piqueras J, Saiz-Ruiz J, Baca-Garcia E. Positive association between SAT-1 -1415T/C polymorphism and anxiety. Am J Med Genet B Neuropsychiatr Genet. 2009; 150:515-519. [PubMed: 18759322]

Varnäs K, Halldin C, Pike VW, Hall H. Distribution of 5-HT4 receptors in the postmortem human brain-an autoradiographic study using [125I]SB 207710. Eur Neuropsychopharmacol. 2003 Aug; 13(4):228-34. [PubMed: 12888181]

Varnäs K, Thomas DR, Tupala E, Tiihonen J, Hall H. Distribution of 5-HT7 receptors in the human brain: a preliminary autoradiographic study using [3H]SB-269970. Neurosci Lett. 2004 Sep 9; 2004367(3):313-6. [PubMed: 15337256]

Vergnes M, Depaulis A, Boehrer A. Parachlorophenylalanine-induced serotonin depletion increases offensive but not defensive aggression in male rats. Physiol Behav. 1986; 36:653-658. [PubMed: 2940609]

Verona E, Joiner TE, Johnson F, Bender TW. Gender specific gene-environment interactions on laboratory-assessed aggression. Biol Psychol. 2006; 71:33-41. [PubMed: 16360879]

Videtic A, Pungercic G, Pajnic IZ, Zupanc T, Balazic J, Tomori M, Komel R. Association study of seven polymorphisms in four serotonin receptor genes on suicide victims. Am J Med Genet B Neuropsychiatr Genet. 2006; 141:669-672. [PubMed: 16856120]

Videtic A, Zupanc T, Pregelj P, Balazic J, Tomori M, Komel R. Suicide, stress and serotonin receptor 1A promoter polymorphism $-1019 \mathrm{C}>\mathrm{G}$ in Slovenian suicide victims. Eur Arch Psychiatry Clin Neurosci. 2009; 259:234-238. [PubMed: 19224112]

Virkkunen M, Goldman D, Nielsen DA, Linnoila M. Low brain serotonin turnover rate (low CSF 5HIAA) and impulsive violence. J Psychiatry Neurosci. 1995; 20:271-275. [PubMed: 7544158]

Waeber C, Sebben M, Nieoullon A, Bockaert J, Dumuis A. Regional distribution and ontogeny of 5HT4 binding sites in rodent brain. Neuropharmacology. 1994; 33:527-541. [PubMed: 7984292]

Walsh MT, Dinan TG. Selective serotonin reuptake inhibitors and violence: a review of the available evidence. Acta Psychiatr Scand. 2001; 104:84-91. [PubMed: 11473500]

Walther DJ, Peter JU, Bashammakh S, Hortnagl H, Voits M, Fink H, Bader M. Synthesis of serotonin by a second tryptophan hydroxylase isoform. Science. 2003; 299:76. [PubMed: 12511643] 
Wasserman D, Geijer T, Sokolowski M, Frisch A, Michaelovsky E, Weizman A, Rozanov V, Wasserman J. Association of the serotonin transporter promotor polymorphism with suicide attempters with a high medical damage. Eur Neuropsychopharmacol. 2007; 17:230-233. [PubMed: 17029913]

Wasserman D, Geijer T, Sokolowski M, Rozanov V, Wasserman J. The serotonin 1A receptor $\mathrm{C}(-1019) \mathrm{G}$ polymorphism in relation to suicide attempt. Behav Brain Funct. 2006; 2:14. [PubMed: 16626484]

Waterhouse BD, Mihailoff GA, Baack JC, Woodward DJ. Topographical distribution of dorsal and median raphe neurons projecting to motor, sensorimotor, and visual cortical areas in the rat. $\mathrm{J}$ Comp Neurol. 1986; 249:460-476. 478-481. [PubMed: 3528236]

Way BM, Lacan G, Fairbanks LA, Melega WP. Architectonic distribution of the serotonin transporter within the orbitofrontal cortex of the vervet monkey. Neuroscience. 2007; 148:937-948. [PubMed: 17766046]

Weder N, Yang BZ, Douglas-Palumberi H, Massey J, Krystal JH, Gelernter J, Kaufman J. MAOA genotype, maltreatment, and aggressive behavior: the changing impact of genotype at varying levels of trauma. Biol Psychiatry. 2009; 65:417-424. [PubMed: 18996506]

Westlund KN, Denney RM, Rose RM, Abell CW. Localization of Distinct Monoamine-Oxidase a and Monoamine-Oxidase B-Cell Populations in Human Brain-Stem. Neuroscience. 1988; 25:439456. [PubMed: 3399053]

Whitaker-Azmitia PM, Zhang X, Clarke C. Effects of gestational exposure to monoamine oxidase inhibitors in rats: preliminary behavioral and neurochemical studies. Neuropsychopharmacology. 1994; 11:125-132. [PubMed: 7840864]

White SM, Kucharik RF, Moyer JA. Effects of serotonergic agents on isolation-induced aggression. Pharmacol Biochem Behav. 1991; 39:729-736. [PubMed: 1686105]

Williams LM, Gatt JM, Kuan SA, Dobson-Stone C, Palmer DM, Paul RH, Song L, Costa PT, Schofield PR, Gordon E. A polymorphism of the MAOA gene is associated with emotional brain markers and personality traits on an antisocial index. Neuropsychopharmacology. 2009; 34:1797-1809. [PubMed: 19194374]

Wilson MA, Molliver ME. The organization of serotonergic projections to cerebral cortex in primates: regional distribution of axon terminals. Neuroscience. 1991; 44:537-553. [PubMed: 1754051]

Witte AV, Floel A, Stein P, Savli M, Mien LK, Wadsak W, Spindelegger C, Moser U, Fink M, Hahn A, Mitterhauser M, Kletter K, Kasper S, Lanzenberger R. Aggression is related to frontal serotonin-1A receptor distribution as revealed by PET in healthy subjects. Hum Brain Mapp. 2009; 30:2558-2570. [PubMed: 19086022]

Witte TK, Merrill KA, Stellrecht NE, Bernert RA, Hollar DL, Schatschneider C, Joiner TE Jr. "Impulsive" youth suicide attempters are not necessarily all that impulsive. J Affect Disord. 2008; 107:107-116. [PubMed: 17804082]

Wyder M, De Leo D. Behind impulsive suicide attempts: indications from a community study. J Affect Disord. 2007; 104:167-173. [PubMed: 17397934]

Xie E, Zhu L, Zhao L, Chang LS. The human serotonin 5-HT2C receptor: complete cDNA, genomic structure, and alternatively spliced variant. Genomics. 1996; 35:551-561. [PubMed: 8812491]

Yen FC, Hong CJ, Hou SJ, Wang JK, Tsai SJ. Association study of serotonin transporter gene VNTR polymorphism and mood disorders, onset age and suicide attempts in a Chinese sample. Neuropsychobiology. 2003; 48:5-9. [PubMed: 12886033]

Yoon HK, Kim YK. TPH2-703G/T SNP may have important effect on susceptibility to suicidal behavior in major depression. Prog Neuropsychopharmacol Biol Psychiatry. 2009; 33:403-409. [PubMed: 19162119]

Yoshimura H, Ogawa N. Ethopharmacology of maternal aggression in mice: effects of diazepam and SM-3997. Eur J Pharmacol. 1991; 200:147-153. [PubMed: 1685120]

Zalsman G, Anderson GM, Peskin M, Frisch A, King RA, Vekslerchik M, Sommerfeld E, Michaelovsky E, Sher L, Weizman A, Apter A. Relationships between serotonin transporter promoter polymorphism, platelet serotonin transporter binding and clinical phenotype in suicidal and non-suicidal adolescent inpatients. J Neural Transm. 2005; 112:309-315. [PubMed: 15657646] 
Zalsman G, Huang YY, Oquendo MA, Burke AK, Hu XZ, Brent DA, Ellis SP, Goldman D, Mann JJ. Association of a triallelic serotonin transporter gene promoter region (5-HTTLPR) polymorphism with stressful life events and severity of depression. Am J Psychiatry. 2006; 163:1588-1593. [PubMed: 16946185]

Zhang J, Shen Y, He G, Li X, Meng J, Guo S, Li H, Gu N, Feng G, He L. Lack of association between three serotonin genes and suicidal behavior in Chinese psychiatric patients. Prog Neuropsychopharmacol Biol Psychiatry. 2008; 32:467-471. [PubMed: 17964050]

Zhang X, Beaulieu JM, Gainetdinov RR, Caron MG. Functional polymorphisms of the brain serotonin synthesizing enzyme tryptophan hydroxylase-2. Cell Mol Life Sci. 2006; 63:6-11. [PubMed: 16378243]

Zhang YQ, Zhang CS, Yuan GZ, Yao JJ, Cheng ZH, Liu CJ, Liu QH, Wan GR, Shi GZ, Cheng YR, Ling Y, Li K. Effect of Tryptophan Hydroxylase-2 rs7305115 SNP on suicide attempts risk in major depression. HYPERLINK "http://www.ncbi.nlm.nih.gov/pubmed/" lo "Behavioral and brain functions : BBF.". Behav Brain Funct. 2010; 6:49. [PubMed: 20738857]

Zhou ZF, Roy A, Lipsky R, Kuchipudi K, Zhu GS, Taubman J, Enoch MA, Virkkunen M, Goldman D. Haplotype-based linkage of tryptophan hydroxylase 2 to suicide attempt, major depression, and cerebrospinal fluid 5-hydroxyindoleacetic acid in 4 populations. Arch Gen Psychiatry. 2005; 62:1109-1118. [PubMed: 16203956]

Zill P, Buttner A, Eisenmenger W, Moller HJ, Bondy B, Ackenheil M. Single nucleotide polymorphism and haplotype analysis of a novel tryptophan hydroxylase isoform (TPH2) gene in suicide victims. Biol Psychiatry. 2004; 56:581-586. [PubMed: 15476687]

Zill P, Preuss UW, Koller G, Bondy B, Soyka M. SNP- and haplotype analysis of the tryptophan hydroxylase 2 gene in alcohol-dependent patients and alcohol-related suicide. Neuropsychopharmacology. 2007; 32:1687-1694. [PubMed: 17251907]

Zouk H, McGirr A, Lebel V, Benkelfat C, Rouleau G, Turecki G. The effect of genetic variation of the serotonin $1 \mathrm{~B}$ receptor gene on impulsive aggressive behavior and suicide. Am J Med Genet B Neuropsychiatr Genet. 2007; 144:996-1002. [PubMed: 17510950] 


\section{Highlights}

- Implications of 5-HT-ergic dysfunctions in aggression and suicide

- Review of the anatomical distribution of the 5-HT-ergic system in brain

- Review of 5-HT receptors, transporter, synthesis and metabolic enzymes

- Interaction of genetic, environmental and gender on aggression and suicide 


\section{Medial prefrontal Cortex}

\section{Hippocampus}

\section{Orbitofrontal cortex}

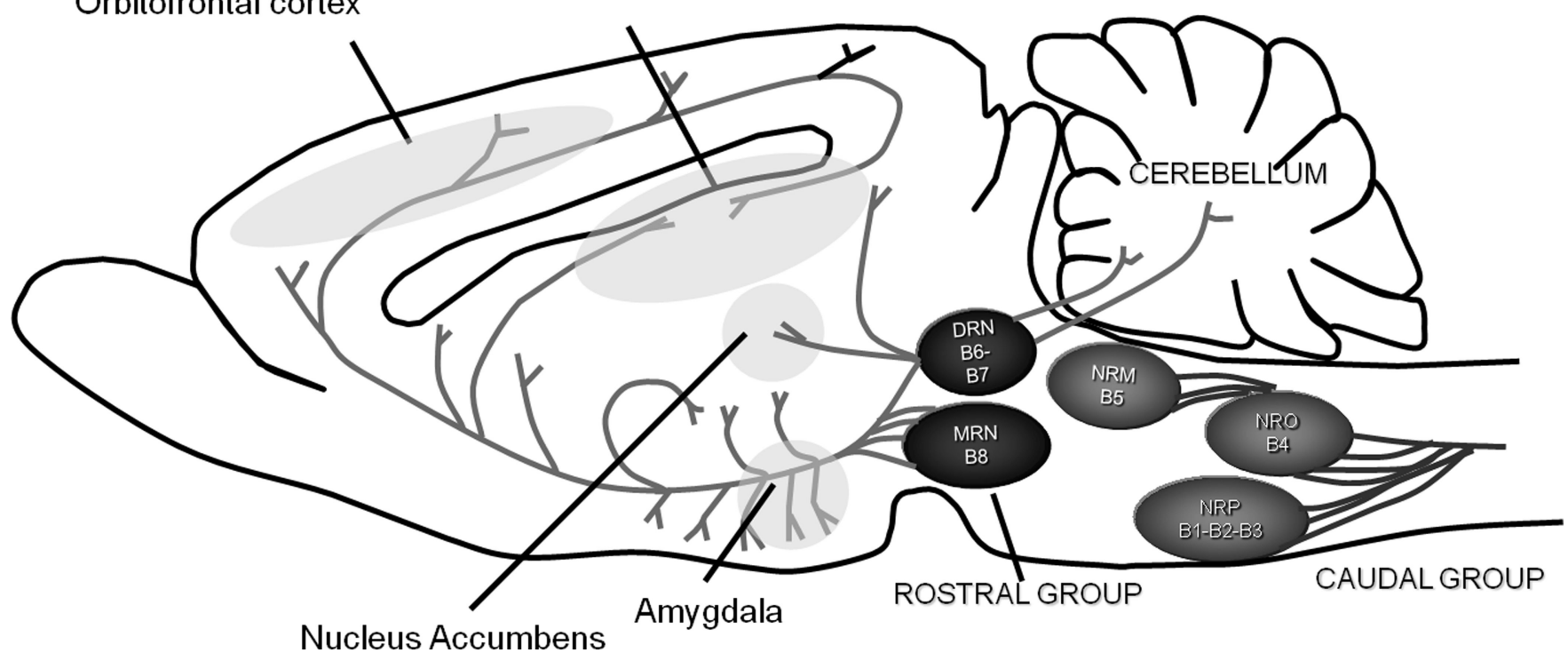

Figure 1.

Midsagittal view of the rat brainstem with serotonin-immunoreactive cell body groups. The ovals encompass the two major subdivisions of the brain serotonergic system.

Abbreviations: DRN, dorsal raphe nucleus; MRN, medial raphe nucleus; NRM; nucleus raphe magnus; NRO, nucleus raphe obscurus. Cell groups $\mathrm{B} 1$ to $\mathrm{B} 9$ according to the terminology of Dahlstrom and Fuxe (Dahlstrom and Fuxe, 1964). 5-HT innervations of the areas involved in aggression and suicide are depicted. 

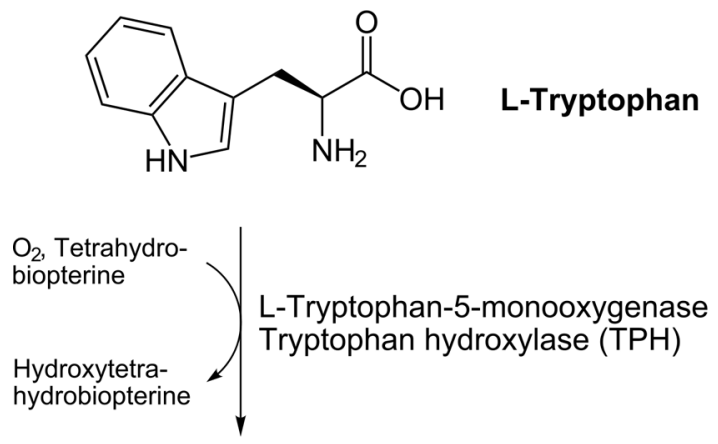

$\mathrm{HO}$<smiles>Cc1ccc2[nH]cc(C[C@H](N)C(=O)O)c2c1</smiles>

5-Hydroxy-L-tryptophan (5-HTP)

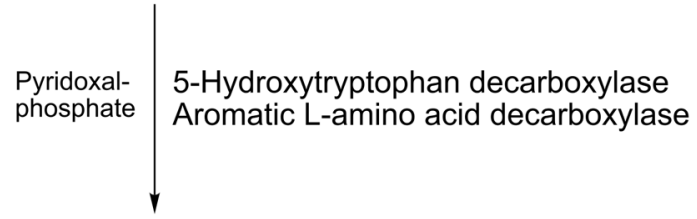<smiles>NCCc1c[nH]c2ccc(O)cc12</smiles>

\section{Serotonin (5-HT)}

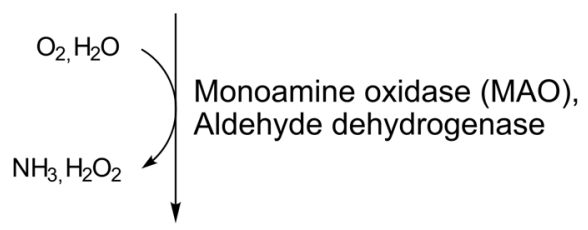<smiles>O=C(O)Cc1c[nH]c2ccc(O)cc12</smiles>

5-Hydroxyindoleacetic acid (5-HIAA)

Figure 2.

The biosynthesis of serotonin. Tryptophan hydroxylase (TPH) catalyzes the first and ratelimiting step in the synthesis of serotonin (5-hydroxytryptamine) using tetrahydrobiopterin and dioxygen as co-substrates and producing water and dihydrobiopterin as byproducts. The second and final reaction in the biosynthesis of serotonin is catalyzed by the aromatic amino acid decarboxylase. Monoamine oxidase (MAO) catalyzes the oxidative deamination of 5HT. 
Table 1

Gene structure and regulation of key serotonergic genes in humans

\begin{tabular}{|c|c|c|}
\hline & Gene Organization & Key transcription factors \\
\hline $5-\mathrm{HT}_{1 \mathrm{~A}}$ & Single exon (intronless) & Sp1, Deaf-1, Freud-1, NRSF, AP-1, CREB, MAZ (Pur- 1, Zif87), NFKB, c-Jun \\
\hline $5-\mathrm{HT}_{1 \mathrm{~B}}$ & Single exon (intronless) & GR, c-Fos, c-Myc \\
\hline $5-\mathrm{HT}_{2 \mathrm{~A}}$ & 3 exons & Sp1, PEA3, AP-1, STAT-3 \\
\hline $5-\mathrm{HT}_{2 \mathrm{C}}$ & 4 exons & CUTL-1 \\
\hline $5-\mathrm{HT}_{3 \mathrm{~A}}$ & 9 exons & GR, NRSF \\
\hline $5-\mathrm{HT}_{3 \mathrm{~B}}$ & 8 exons & IRF-7A, POU2F2, Meis-1, Oct-B1 \\
\hline $5-\mathrm{HT}_{4}$ & At least 10 exons (multiple splice variants) & NRSF1, NRSF2, CREB \\
\hline $5-\mathrm{HT}$ & 3 exons & Sp1, CREB \\
\hline $5-\mathrm{HT}_{7}$ & 4 exons (multiple splice variants) & NF-Y, Sp1, TBP, TFIID \\
\hline $\mathrm{TPH}_{1}$ & 11 exons & POU3F2, NRSF, GR \\
\hline $\mathrm{TPH}_{2}$ & 11 exons & YB-1, CTCF, GR, NFKB \\
\hline $5-\mathrm{HTT}$ & 14 exons & Sp1, R1, GR, Egr-1, c-Jun, AP-1 \\
\hline MAOA & 15 exons & \\
\hline
\end{tabular}


Table 2

\begin{tabular}{|c|c|c|}
\hline \multicolumn{2}{|c|}{ Polymorphisms of 5-HT2A } & References \\
\hline Promoter region & A-1438G, C-1420T, A-1273G, A-1182G, A-783G, G-561A, C-559T, G-400A, A-311G & Myers et al., 2007 \\
\hline Coding region & Thr25Asn, 1le197Val, Ser421Phe, Ala447Val, His452Tyr & Davies et al., 2006 \\
\hline Silent & T102C, C516T & Spurlock et al., 1998 \\
\hline
\end{tabular}


Table 3

The two tryptophan hydroxylase isoforms, their location and corresponding physiological and pathological function of central or peripheral serotonin systems

\begin{tabular}{|c|c|}
\hline \multicolumn{2}{|c|}{ Tryptophan hydroxylase isoform } \\
\hline TPH1 & TPH2 \\
\hline \multicolumn{2}{|c|}{ Location } \\
\hline Enterochromaffin cells, pineal body & Brain \\
\hline \multicolumn{2}{|c|}{ Physiological functions of serotonin } \\
\hline Melatonin synthesis & Food intake and body weight \\
\hline Vasoconstriction & Sleep \\
\hline Haemostasis & Behavior \\
\hline Immune system & Mood \\
\hline Intestinal motility & Thermoregulation \\
\hline Serotonin in pathology of diseases \\
\hline Migraine & Migraine \\
\hline Carcinoid & Neuropsychiatric disorders \\
\hline & Obesity \\
\hline
\end{tabular}

